\title{
DIAGNÓSTICO E TIPIFICAÇÃO DE SISTEMAS DE PRODUÇÃO: PROCEDIMENTOS PARA ACCOEES DE DESENVOLVIMENTO REGIONAL
}

JAIME AIRTON WÜNSCH

Dissertação apresentada à Escola Superior de Agricultura "Luiz de Queiroz", da Universidade de São Paulo, para a obtenção do título de Mestro em Agroncrnia, Área do Concentração: Fitotecnia.

PIRACICABA

Estado de São Paulo - Brasil

Março - 1995 


\title{
DIAGNÓSTICO E TIPIFICAÇÃO DE SISTEMAS DE PRODUÇÃO : PROCEDIMENTOS PARA AÇÕES DE DESENVOLVIMENTO REGIONAL
}

\author{
JAIME AIRTON WÜNSCH \\ Engenheiro Agrônomo
}

Orientador: Prof. Dr. ANTÔNIO LUIZ FANCELLI

Dissertação apresentada à Escola Superior de Agricultura "Luiz de Queiroz", da Universidade de São Paulo, para a obtenção do título de Mestre em Agronomia, Área de Concentração Fitotecnia.

PIR A C I C A B A

Estado de São Paulo - Brasil

Março - 1995 
Ficha catalográfica preparada pela Seção de Livros da Divisão de Biblioteca e Documentação - PCLQ/USP

W966d Wünsch, Jaime Airton

Diagnóstico e tipificação de sistemas de produção: procedimentos para ações de desenvolvimento regional. Piracicaba, 1995. $178 \mathrm{p}$.

Diss. (Mestre) - ESALQ

Bibliografia.

1. Desenvolvimento agricola 2. Sistema agricola Metodologia 1. Escola Superior de Agricultura Luiz de Queiroz, Piracicaba 


\section{DIAGNÓSTICO E TIPIFICAÇÃO DE SISTEMAS DE PRODUÇÃO : PROCEDIMENTOS PARA AÇÕES DE DESENVOLVIMENTO REGIONAL}

JAIME AIRTON WÜNSCH

Aprovada em : 29 de março 1995

Comissão Julgadora:

Prof. Dr. Antônio Luiz Fancelli

Prof. Dr. José Ferreira de Noronha

Prof. Dr. Benedito Silva Neto
ESALQ/USP

ESALQ/USP

DEAg/UNIJUI

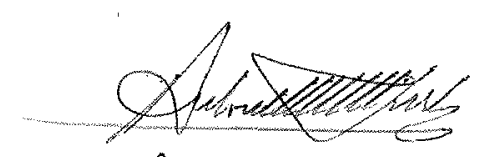

Prof. Dr. ANTÔNIO LUIZ FANCELLI

Orientador 
À minha companheira Cristian e aos meus filhos, Diogo e Júlia, dedico. 


\section{AGRADECIMENTOS}

Ao professor Dr. Antônio Luis Fancelli por sua serena orientação, por sua abertura e confiança en acolher sob sua direção o trabalho que tomou corpo nesta dissertação.

Ao professor Dr. José Ferreira de Noronha e ao professor Dr. Benedito Silva Neto, membros da banca examinadora, pelas críticas e sugestões que fizeram.

Aos colegas do Departamento de Estudos Agrários da Universidade de Ijuí (UNÍJUI) pelo apoio e compreensão revelados nos momentos mais dificeis da elaboração deste trabalho.

À direção da UNÍJUI pelo apoio e incentivo dado ao autor para os estudos de pós graduação.

Ao Conselho Nacional de Desenvolvimento Científico e Tecnológico $(\mathrm{CNPq})$, pela bolsa de estudo recebida. 


\section{SUMÁRIO}

Página

RESUMO

vii

SUMMARY

$\mathrm{x}$

1.INTRODUÇÃO

2. REVISÃO DA LITERATURA. 05

2.1. Gênese do interesse pela Pesquisa-Desenvolvimento e a abordagem 05 sistêmica

2.1.1. A Pesquisa-Desenvolvimento : método de pesquisa pluridisciplinar, sistêmico e dinâmico

2.1.2. A abordagem sistêmica : uma metodologia de estudo e representação de fenômenos complexos

2.1.2.1. Conceituação de sistema 18

2.1.2.2. Aspectos do processo de modelização sistêmica 20

2.2. Os conceitos centrais da abordagem sistêmica aplicados a agricultura 27

2.2.1. O conceito de sistema agrário. 29

2.2.2. Do sistema de produção ao sistema família-estabelecimento 30

2.2.3. Sistema de cultivo: um conceito operatório da agronomia 33

2.2.4. Os conceitos de sistema de criação e de sistema forrageiro 37 
2.3. O diagnóstico do estabelecimento agrícola ........................................ 38

2.3.1. As práticas : objeto central do diagnóstico ................................ 40

2.3.2. A abordagem global do estabelecimento agrícola

2.3.2.1. Considerações sobre o estudo do estabelecimento agrícola como um sistema

2.3.2.2. A decisão do agricultor : o modelo do comportamento adaptativo

2.3.3. Tipologia do funcionamento : instrumento para o estudo regional dos estabelecimentos agrícolas

3. DISCUSSÃO 64

3.1. Pesquisa-Desenvolvimento e abordagem sistêmica : interesse e limitações ... 64

3.2 O diagnóstico do estabelecimento agrícola : aportes, dificudades e limites 72

3.3. Interesse e limites dos métodos tipológicos 78

4. PROPOSIÇÃO METODOLÓGICA 82

4.1. O diagnóstico global : principios metodológicos

4.2. Operacionalização do procedimento : guia de estudo do conjunto família/sistema de produção 88

4.3. Modelização da diversidade regional dos sistemas de produção : a tipologia de funcionamento e as trajetórias de evolução 94

4.4. Os procedimentos para construir a tipologia e as trajetórias de evolução ..... 96

4.5. Guia de estudos : instrumento de diagnóstico global da unidade de produção agrícola 


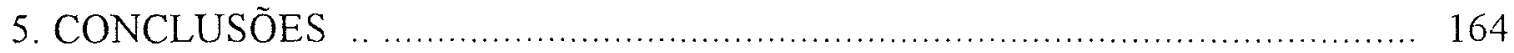

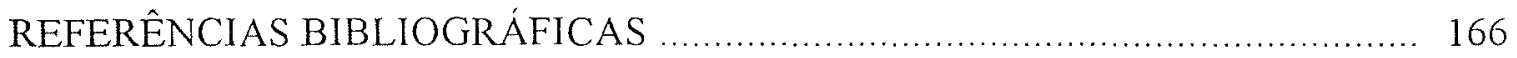

APÊNDICE 1 : Representação da unidade de produção vista como um sistema de produção

APÊNDICE 2 : Representação do modelo de comportamento adaptativo.

APÊNDICE 3 : Esquema do desenrolar do diagnóstico e tipificação dos sistemas de 178 produção de uma pequena região 


\title{
DIAGNÓSTICO E TIPIFICAÇÃO DE SISTEMAS DE PRODUÇÃO : PROCEDIMENTOS PARA AÇÕES DE DESENVOLVIMENTO REGIONAL
}

\author{
Autor : JAIME AIRTON WÜNSCH \\ Orientador : PROF. DR. ANTÔNIO LUIZ FANCELLI
}

\section{RESUMO}

Reconhecendo que para a geração e difusão de inovações e melhorias técnicas é essencial conhecer as condições para sua operacionalização, elaborou-se uma metodologia de diagnóstico das unidades de produção agrícola de uma região.

Os pressupostos da metodologia são: (a) a unidade de produção é considerada um sistema aberto, organizado com vista a atingir os objetivos do empreendedor e confrontada a condicionantes internos e externos; (b) em uma região há uma diversidade de maneiras de produzir, independentemente das restrições impostas pelo meio natural sobre as atividades e da disponibilidade desigual de fatores de produção.

Através de enquetes diretas aplicadas a uma amostra são obtidas as informações para fazer o diagnóstico global, construir a tipologia de funcionamento e as trajetórias de evolução dos tipos identificados.

Previamente, são obtidas classes de unidades de produção através do cruzamento das informações relativas as grandes variações do meio natural e do meio 
sócio-econômico com os dados censitários sobre a dimensão dos estabelecimentos e as atividades produtivas praticadas. A amostra é extraída no interior destas classes.

Para realizar as entrevistas e tratar os dados utiliza-se o guia de estudo, que é composto de três partes. Na primeira parte, é elaborada o esquema de funcionamento do sistema de produção a partir das seguintes informações : características das atividades produtivas; os objetivos de médio e longo prazo do empreendedor; as potencialidades e restrições das terras, mão de obra, equipamentos, instalações, fornecedores, compradores e serviços; a história do estabelecimento. $\mathrm{Na}$ segunda parte, é examinado o funcionamento e os resultados técnicos e econômicos das atividades, avaliando-se sua eficiência segundo uma lógica setorial. Na última parte, o esquema de funcionamento inicial é reorganizado em função das incoerências e problemas detectados na segunda parte e, após o julgamento, são feitas as propostas de mudanças.

O julgamento do funcionamento é realizado através : (a) da verificação da adequação entre a maneira de organizar e de conduzir as atividades e os objetivos detectados; (b) da avaliação das performances das atividades e da eficiência das transformações; (c) da avaliação da reprodutibilidade global, agronômica, zootécnica e econômica, do sistema de produção.

Com base nas informações das enquetes e em sucessivas sinteses comparativas entre as unidades amostradas é construída a tipologia regional. A tipologia consiste em uma classificação das unidades que apresentam funcionamento semelhante em um certo número de tipos, usando-se como critérios os objetivos do empreendedor, as características e estratégias dos sistemas de produção.

As trajetórias de evolução dos tipos correspondem a descrição das etapas e mecanismos que deram origem aos atuais tipos, sendo deduzidas das histórias 
individuais e da história da região

A metodologia proposta permite diagnosticar os pontos fortes e fracos dos sistemas de produção e representar sua diversidade regional. Contribui assim, para definição de linhas de pesquisa e ações prioritárias adaptadas às condições sociais, econômicas e ambientais. 


\title{
DIAGNOSTIC ASSESSMENT AND TYPIFICATION OF FARMING SYSTEMS : \\ PROCEDURES FOR THE REGIONAL DEVELOPMENT ACTIVITIES
}

\author{
Author : JAIME AIRTON WÚNSCH \\ Adviser : PROF. DR. ANTÔNIO LUIZ FANCELLI
}

\section{SUMMARY}

Having in mind that for creation and extension of technical improvements it is essential to know the conditions for its implementation, a method of diagnostic was developed for the agricultural production of an area.

The parameters of this methodology are: (a) the farm is considered an open system, organized in order to attempt the objectives of the contractor, considering internal and external conditions; (b) in an area, there are several producing ways, independent from the natural restrictions on the activities and the unequal availability of productive factors.

The available informations can be obtained by direct surveys on a sample, for make the farm check up, create the functioning tipology and the evolution trajetory of the farming systems.

Previously, through crossing the informations of environment conditions, social economics conditions, together with the assessment data on the farms dimensions 
and productives activities, classes were onbtained. In the inner part of this classes the sample was taken for the survey.

In order to carry out the intervews and data assessment, a handbook is used, consisting of three parts. In the first part, the purpose is made of a model representation of farm functioning, which come from the following informations : the activity characteristics; the objectives on medium and long terms of the contractor; the assets and constraints of the land, labour force, equipment, farm building, supplies, buyers and services; the setting up history. In the second part, the functioning is examined, along with the technical and economical activities results, assessing its efficiency according to the sectorial logic. In the last part, the initial model is reorganized considering the incoherences and the detected problems in the second part. After the assessment, proposals for changes are made.

The assessment is carried out in three ways: (a) the cheeking of the adequacy comparing how to organize and carry out the activities, and the detected objectives; (b) the assessment of the performances in the activities, and transformations efficiency; (c) the assessment of sustainability, agronomic, in animal husbandry and economic of the farming system.

From the inquiries, and the synthesis among the farms, the regional typology is built. The typology consists in the farm classification which present a similar functioning in a certain number of types. The criterions for the classification are : the contractor objectives, the characteristics and the productions strategies of the farming system.

The evolutions trajetories of the types, which is a description of stages and 
mechanisms originating the actual types, are deducted from the individual history of each, and of the area.

The suggested methodology allows to appraisal the strong and weak points in the farming systems and, it represents the regional diversity as well. In this way contributing for the definition of the research lines, priority action adapted to social conditions, economic and environment as well. 


\section{INTRODUÇÃO}

O fracasso de muitos projetos de desenvolvimento agrícola, seja por não atingir a maioria dos produtores visados, seja por provocar consequeencias danosas imprevistas, ou por incentivar um modelo tecnológico de alto custo econômico e energético, promoveu uma reflexão sobre os métodos de pesquisa e de extensão rural.

Um conjunto de experiências aconteceu durante a década de $70 \mathrm{em}$ diversas regiões do mundo, tendo por fundamento o reconhecimento de que o êxito dos projetos de desenvolvimento dependiam do conhecimento prévio das condições reais da produção e que os agricultores tinham um papel relevante na determinação dos problemas e soluções.

Gradativamente estruturou-se uma área de pesquisa denominada de pesquisa em sistemas de produção, tradução da denominação inglesa farming systems research, e pesquisa-desenvolvimento, recherche-développement, designação equivalente, utilizada nos paises francofônicos.

Este tipo de pesquisa pode ser caracterizado, esquematicamente, pelo 
cumprimento de uma seqüência metodológica :diagnóstico finalizado, seguido da experimentação e análise dos resultados das proposições técnicas, econômicas e gerenciais e em uma terceira etapa, extensão e extrapolação dos resultados obtidos através de diversos mecanismos de difusão e formação.

Inverteu-se deste modo, o caminho clássico que vai da pesquisa em estações experimentais ao estabelecimento agrícola, passando-se a conduzir a experimentação em condições reais

Não se trata entretanto, em apenas transferir a experimentação agrícola ao meio rural. A pesquisa em sistemas de produção, fundamentalmente, procura construir suas hipóteses de trabalho considerando as práticas de exploração agrícola do meio natural pela população rural que vive em um determinado espaço geográfico. É por esta razão que neste tipo de pesquisa é dada grande importância ao diagnóstico da situação inicial. As linhas de pesquisa e de ação são deduzidas deste diagnóstico.

O processo de produção agrícola, de outra parte, organiza-se em diferentes niveis hierárquicos - a parcela cultivada, lotes de animais, a unidade de produção agrícola, a regiào, o país - que mantém diversas relações entre si. O nível de organização unidade de produção é especialmente importante para a ação de desenvolvimento, pois é o centro da artificialização do ambiente e a célula econômica básica do processo de produção agrícola.

O diagnóstico da unidade de produção agrícola não consiste em apenas caracterizar as conseqüências das técnicas sobre o meio biofísico e a produção agrícola, 
mas examinar também as condições para a operacionalização destas técnicas e entender as razões para sua escolha pelos agricultores.

Ao aceitar-se o desafio de compreender e agir considerando a s condições em que se realiza a produção, aceita-se a complexidade e a diversidade das práticas de produção e de gestão dos agricultores. Complexidade, pois as práticas se organizam em um sistema complexo, a unidade de produção, constituída de um grande número de elementos em interação dinâmica. Diversidade, pois em um espaço geográfico as condições de produção e as maneiras de produzir dos agricultores são muito diferenciadas.

A problemática do diagnóstico assim percebida, implica em articular um conjunto de conceitos e conhecimentos em torno de uma metodologia.

O presente trabalho se insere neste esforço de construção de uma metodologia capaz de identificar e hierarquizar os problemas técnicos, gerências e econômicos enfrentados pelos agricultores de uma região, ao nivel de seus sistemas de produção.

O objetivo deste trabalho foi o de elaborar uma metodologia que permita articular em um único procedimento o diagnóstico global da unidade de produção agrícola e a representação da diversidade de sistemas de produção existentes em uma região.

O ponto de vista de análise e avaliação privilegiado, na metodologia de diagnóstico elaborada, foi o do engenheiro agrônomo generalista, interessado nas 
condições de operacionalização das intervenções técnicas e na criação de inovações adaptadas à situação e aos projetos dos agricultores. 


\section{REVISÃO DA LITERATURA}

\subsection{Gênese do interesse pela Pesquisa-Desenvolvimento e a abordagem sistêmica}

A constatação da deterioração da situação agrícola e alimentar de numerosos paises do Terceiro Mundo, o estudo dos impactos sociais e ambientais do acelerado processo de modernização da produção agrícola nestes países, promovidos pela Revolução Verde ${ }^{1}$ de um lado; a reconsideração dos custos energéticos e financeiros do modelo tecnológico proposto e a incapacidade de atingir a grande maioria dos agricultores, em especial os mais pobres, de outro lado, provocou uma reflexão profunda sobre o modelo de ciência e tecnologia a serviço do desenvolvimento agricola.(INRA-SAD, 1985; SIMMONDS, 1986; SANDS, 1986; HECHT, 1987; FAO, 1989; MAZOYER, 1991; SASSON, 1993).

A simples constatação da resistência dos agricultores a penetração das inovações tecnológicas e organizacionais elaboradas em outros contextos sociais,

1 A Revolução Verde consistiu essencialmente na difusão nos países do Terceiro Mundo, de variedades de cereais de alto potencial genético. Selecionadas por seu potencial de rendimento fisico, estas variedades deveriam assegurar aos agricultores um aumento imediato da produção. A expressão de todo seu potencial exige um conjunto de insumos de natureza industrial e um manejo tal, que provocam uma modificação completa dos sistemas técnicos de produção tradicionais. 
econômicos e institucionais era insuficiente para compreender os fracassos de inúmeros projetos de desenvolvimento agrícola incentivados e financiados sob a égide da Revolução Verde (PELLECUER et alii, 1987). Na concepção de desenvolvimento agrícola, predominante até então, os agricultores se dividiam entre os modernos, mais permeáveis as inovações técnicas e organizacionais, e os agricultores tradicionais, que devido a sua mentalidade conservadora resistiam as melhorias propostas pelos técnicos e instituições de apoio a agricultura. O desenvolvimento consistiria em adaptar os agricultores ao projeto técnico formulado pelos pesquisadores especialistas e as instituições reconhecidas como responsáveis pelo desenvolvimento (KROLL, 1985).

Predominava uma visão tecnocrática e normativa do progresso técnico, baseada na idéia de que haveria um modelo técnico único e em um julgamento da tecnicidade do homem pelos resultados técnicos alcançados independentemente das condições de sua obtenção (SEBILLOTTE, 1979).

KROLL (1985), nota que o discurso dominante socialmente em termos de desenvolvimento agrícola não se organiza em torno de uma concepção claramente definida do processo, mas sobre os resultados presumidos do desenvolvimento.

A pergunta formulada por BOURGEOIS (1983a) é precisa : se os resultados da evolução das técnicas agrícolas não são de todo satisfatórios, não seria também em razão das lógicas e dos métodos que tem servido de base a sua elaboração e difusão?

O modelo institucional de geração e difusão de tecnologia predominante, era do tipo linear. Neste modelo os agricultores seriam meros receptores de conhecimentos e informações gerados pelos pesquisadores em centros de 
experimentação e os extensionistas os intermediários entre a adoção e a geração (GENTIL, 1984).

Para LEFORT \& PASQUIS (1982) e LEFORT (1982) as relações entre a pesquisa e o desenvolvimento são fortemente marcadas por um esquema racionalista que se caracteriza : pela anterioridade das pesquisas em relação a difusão de técnicas; por uma hierarquia da ciência e pela especialização de tarefas, deixando à pesquisa o monopólio da inovação; pela linearidade das transferências técnicas, o que distancia cada vez mais os agricultores da reflexão bem como da experimentação.

Este esquema relacional não corresponde contudo a realidade social rural, pois a inovação tecnológica tal qual ocorre na prática social, opera por vias complexas e interativas. Os pesquisadores tem o conhecimento do procedimento científico assim como os extensionistas e os produtores tem o conhecimento do meio rural e das práticas agrícolas, porém nenhum deles tem o monopólio da inovação, da experimentação e da melhoria das técnicas (LEFORT \& PASQUIS, 1982)

A questão que se colocava era como tornar complementar as medidas da pesquisa e do desenvolvimento agrícola, como unificá-las em um mesmo objetivo e método (TREBUIL \& DUFUMIER, 1983)?

De outra parte, o progresso técnico que se verificou na agricultura como um todo provocou a emergência de questões e problemas que não podiam ser abordados por só algumas disciplinas científicas isoladas ou só através da análise da produção. Questões concernentes por exemplo, a adequada utilização de zonas marginais pois não adaptadas ao tipo de conhecimento produzido, a margem de manobra entre as sofisticadas técnicas criadas, o crescimento dos custos de produção, as exigências em 
trabalho, os limites de quantidade e qualidade impostos as produções pelo mercado e a fragilidade crescente dos cultivos, passaram a interessar a pesquisa (INRA/SAD, 1985).

O debate científico e a experiência de trabalho, em especial nos países em desenvolvimento, permitiu que se alcançasse a partir da segunda metade dos anos 70 um certo consenso entre os organismos internacionais de pesquisa, planejamento e financiamento, sobre um conjunto de recomendações que deveriam orientar os novos métodos e abordagens do desenvolvimento agrícola (SIMMONDS, 1985; JOUVE, 1986). JOUVE (1986) as sintetiza como segue:

a) considerar mais profundamente as condições reais de produção agrícola, ou seja, observar e levar em conta a diversidade de condições e modalidades de exploração do meio pelas comunidades rurais na definição dos programas de pesquisa;

b) compreender que mudanças técnicas estão em estreita interação com as mudanças sociais e econômicas, consequentemente para a criação e a difusão das inovações técnicas e organizacionais devem ser consideradas as condições sociais e econômicas de sua apropriação pelos produtores. Isto implica em substituir a idéia de uma ruptura na evolução das sociedades agrárias em proveito da busca de transformações progressivas de seu funcionamento;

c) reconhecer que toda as transformações das condições e modalidades de exploração do meio rural necessita da adesão dos produtores que realizam esta exploração, isto é, a participação destes é indispensável na concepção, execução e avaliação dos programas e projetos de desenvolvimento. A concretização desta idéia implica que se propicie as condições para que os agricultores se organizem e assim possam efetivamente ter responsabilidades no processo de desenvolvimento reduzindo 
sua dependência e muitas vezes sua resistência as proposições dos organismos de apoio a agricultura.

Trata-se, como frisou DUFUMIER (1985), de reconhecer a diversidade e complexidade dos sistemas de produção praticados pelos agricultores e de considerar a variedade de objetivos que os agricultores definem para a sua unidade produtiva.

LANDAIS \& DEFFONTAINES (1990), caracterizam esta abordagem como uma abordagem das técnicas agrícolas que considera os agricultores e agricultoras como decididores e atores, e que se interessa de maneira privilegiada pelas práticas agrícolas, quer dizer sobre os modos com que as técnicas são concretamente realizadas no contexto do estabelecimento agrícola, bem como no conjunto da sociedade local, marcadas por sua história, seu território, seu funcionamento.

Para dar conta desta nova maneira de ver a relação da ciência e a tecnologia com o desenvolvimento agrícola foi necessário elaborar um conjunto coerente de conceitos e conhecimentos e uma metodologia flexível que associasse a experimentação biotécnica e a observação in situ.

O esforço de formalização originou a Pesquisa-Desenvolvimento, denominação francesa (Recherche Devellopement), e a Pesquisa em Sistemas de Produção (Farming Systems Research) denominação empregada nos países anglofônicos (FRESCO, 1984; SIMMONDS, 1986; SANDS, 1986; PILLOT, 1987).

Para analisar as condições e modalidades de exploração agrícola do meio pelas comunidades rurais em toda a sua diversidade e complexidade e adaptar as inovações a esta diversidade de situações, considerando as diferentes contribuições disciplinares fez-se necessário um conjunto de instrumentos e métodos construídos para 
esta finalidade. É precisamente a abordagem do meio e da produção rural fundamentada na análise de sistemas que fornecerá uma parte importante destes instrumentos e métodos (JOUVE, 1986).

A Pesquisa-Desenvolvimento distingue-se da análise sistêmica. A primeira é um modo de organizar a pesquisa aplicada a uma dada situação. A abordagem sistêmica aparece como fornecedora de instrumentos metodológicos para a análise da situação, o diagnóstico, e como quadro dentro do qual se organiza um conjunto coerente de conceitos e conhecimentos espalhados em diferentes disciplinas favorecendo uma atividade de pesquisa pluridisciplinar (INRA/SAD, 1985).

\subsubsection{A Pesquisa-Desenvolvimento : método de pesquisa pluridisciplinar, sistêmico e dinâmico}

A Pesquisa-Desenvolvimento é um procedimento aplicado de maneira sistemática na indústria há muito tempo. Consiste em analisar diferentes etapas do processo de fabricação e em experimentar as melhorias possíveis em função dos objetivos procurados pela direção da empresa (JOUVE, 1986).

A pesquisa com e para o desenvolvimento da agricultura, é definida como a experimentação em meio físico e social real, em verdadeira escala, das possibilidades e condições de mudança técnica e social do meio rural. A escala verdadeira onde o espaço de intervenção, definidos os limites físicos, é de fato determinado pelas condições institucionais que regulam a mobilidade dos fatores de produção e a rigidez das relações de produção (BILLAZ \& DUFUMIER, 1980). 
A agricultura e seus atores deixa de ser apenas o destinatário das melhorias agronômicas elaboradas nos laboratórios e estações experimentais, passando a ser fonte direta de problemas, de hipóteses científicos e local de realização e avaliação das pesquisas. A unidade de produção, lugar onde se toma as decisões mais determinantes no que concerne a exploração do meio natural, associa-se como local de geração e difusão tecnológica a estação experimental e aos laboratórios (SEBILLOTTE, 1974; MILLEVILLE,1987). O agricultor passa a ser um interlocutor do pesquisador na identificação dos problemas e teste de soluções (JOUVE, 1991).

Em lugar da organização linear e descendente das relações entre pesquisadores, extensionistas e agricultores, propõe-se uma relação triangular recíproca entre os três atores do desenvolvimento.(BILLAZ \& TOURTE, 1982). Assim, se a pesquisa quiser facilitar a inovação e a apropriação das tecnologias propostas, ela deve se inserir em uma nova prática, no e com o processo de desenvolvimento rural ( LEFORT \& PASQUIS, 1982) o que implica em reconhecer que os agricultores e extensionistas são também experimentadores. A participação dos agricultores na geração de tecnologias, a criação de inovações que respondem a problemas identificados nos sistemas de produção existentes e seu teste em condições reais facilitam sua aceitação pelos agricultores (GENTIL, 1984).

O procedimento proposto fundamentalmente inverte o processo clássico de intervenção na agricultura, que vai da experimentação à unidade de produção. Partese de um diagnóstico prévio das condições de produção, deduzindo daí os eixos de pesquisa e ação mais adequados às condições identificadas (CAPILLON, 1985; JOUVE, 1992). 
O postulado de atraso dos agricultores dá lugar a um novo postulado, o da coerência. Os agricultores tem um comportamento racional, quer dizer que há coerência entre os objetivos que buscam alcançar e os meios operacionalizados para atingi-los. Para BROSSIER (1973) os agricultores tem boas razões de fazer o que fazem.

$\mathrm{O}$ conceito de fato técnico revelou-se fecundo sob este ponto de vista. O fato técnico é definido como resultado da articulação entre de uma parte os efeitos que as técnicas produzem sobre as produções e sobre a unidade de produção, e de outro parte, as condições de sua efetivação pelo agricultor e a coletividade que as operam em um território (INRA/SAD, 1985; OSTY, 1990). Assim, os fatos técnicos aparecem como um ponto de vista sobre as técnicas, que consiste em considerar estas como o resultado, a um momento dado, de uma evolução e de um jogo de interações com um determinado meio tanto físico como economico (GRASS et alii, 1989).

Ao considerar, de um lado os efeitos das intervenções técnicas e de outro as condições de sua escolha ao nível do estabelecimento, o engenheiro agrônomo pode prever as adaptações técnicas necessárias para a diversidade de situações e desta maneira participar na elaboração de uma metodologia de desenvolvimento (OSTY, 1990).

A aposta feito pelos pesquisadores foi que o fato técnico poderia ser objeto de uma análise científica, que não era tratado nem pelas disciplinas biotécnicas, nem pelas ciências sociais (INRA/SAD, 1985; OSTY, 1990). 
SAUTTER (1985) nota que há desta forma, um enriquecimento temático da agronomia ${ }^{2}$ um alargamento de sua problemática, que repousa sobre a tomada em consideração do meio rural, não como um dado fechado a partir de uma maior ou menor número de parâmetros, mas enquanto uma organização dotada de uma dinâmica, e onde seu estado, é a todo momento, função da maneira com que é usado.

PILLOT (1987) nota que mesmo havendo acordo quanto a necessidade de compreender os sistemas agrícolas previamente a introdução da inovação tecnológica, as finalidades objetivas das operações de Pesquisa-Desenvolvimento diferem. Estas diferenças estam relacionadas a natureza das instituições que as comandam. $\mathrm{O}$ autor distingue três grupos de operações : operações nas quais se busca difundir técnicas ou variedades pré-elaboradas, a partir da identificação de potenciais usuários e eventualmente adaptando os produtos para conseguir uma difusão mais extensa, caracterizando operações do tipo descendente de promoção técnica; um segundo tipo de operação que tem por objeto o desenvolvimento da agricultura camponesa, em que procura-se observar e analisar os sistemas agrícolas antes do que qualquer intervenção, sem nenhum 'a priori' sobre as soluções possíveis de aportar, caracterizando uma abordagem ascendente de promoção dos camponeses; e, um terceiro

\footnotetext{
2 Na literatura francesa há duas acepções do termo agronomia. A agronomia sensu stricto é definida como o estudo diacrônico e sincrônico das relações no interior do comjunto constituído pela população vegetal, o clima e o solo, submetido a ação do homem, com vistas a uma produção (SEBILLOTTE, 1974). A agronomia lato sensu é o conjunto de disciplinas científicas que estudam os problemas que se colocam a prática agrícola, com exceção daqueles tratados pela medicina veterinária. Quando são empregados os termos agronomia ou agronômo esta-se referindo a primeira acepção e quando ésão usados os termos engenharia agronômica e engenheiro agronômo esta-se reportando a segunda acepção.
} 
tipo de operação que tem a finalidade de compreender e avaliar os condicionantes macroeconômicos e políticos do desenvolvimento e preparar quadros para atuar, ou seja, o interesse deste tipo de Pesquisa-Desenvolvimento ultrapassa a simples apropriação de inovações, o autor denomina esta abordagem de desenvolvimento rural.

LEFORT \& PASQUIS (1982) fazem uma distinção semelhante. A Pesquisa-Desenvolvimento descendente tem a finalidade de engendrar soluções pilotos que facilitariam uma mudança na trajetória potencial dos sistemas de exploração agrícola. Este tipo de pesquisa é apropriado às inovações com menor dependência dos fatores naturais e humanos locais. Por outro lado, as operações ascendentes são obrigatoriamente localizadas e plenamente ligadas ao meio rural interessado e buscam apreender o conjunto do processo de desenvolvimento dos sistemas de produção e/ou dos sistemas agrários existentes, analisando seus problemas, identificando rapidamente as soluções possíveis, experimentando-as diretamente nos sistemas estudados.

Para LEFORT \& PASQUIS (1982), distinguir e opor os dois tipos de Pesquisa-Desenvolvimento, ascendentes e descendentes, é limitar a ação dos agentes do desenvolvimento e restringir a gama de possibilidades de evolução dos sistemas praticados pelos agricultores. Para estes autores é na integração destes dois tipos de procedimentos que a Pesquisa-Desenvolvimento poderá ser útil.

Em síntese, o processo de geração e difusão de tecnologias passa a ser concebido em uma perspectiva de desenvolvimento tentando superar o viés setorial e tecnicista predominante na pesquisa agrícola (INRA/SAD, 1985). Os engenheiros agrônomos passam a se colocar o problema global da gestão técnica do estabelecimento agrícola tal qual se coloca o agricultor (LANDAIS \& DEFFONTAINES, 1990). 
De uma forma geral, o procedimento seguido no desenrolar de uma operação de Pesquisa-Desenvolviemnto pode ser dividido em três fases (LEFORT \& PASQUIS, 1982; LEFORT, 1982; JOUVE, 1986; PILLOT,1986) :

1) o diagnóstico finalizado do meio rural, o que implica em aproximações sucessivas entre o modelo de hipóteses explicativas inicialmente formulado e as problemáticas evidenciadas;

2) a constituição de um referencial adaptado, baseado sobre a experimentação e/ou enquete técnica e sócio-economica, e sustentado nas inovações introduzidas ou nas respostas parciais já apresentadas;

3) avaliação, seguida da difusão e apropriação pelos agricultores destas inovações.

É importante notar que estas três fases, são muito interdependentes e não se separam cronologicamente. Um diagnóstico não é nunca definitivo e o acompanhamento da apropriação das técnicas e tecnologias retroalimenta e precisa o diagnóstico (PILLOT, 1984; JOUVE, 1986).

A Pesquisa-Desenvolvimento na agricultura associa duas funções complementares, a de avaliação e a de experimentação (TREBUIL \& DUFUMIER, 1983). A função de avaliação cobre os campos agro-ecológicos, agronômicos, sócioeconomicos, combinando-se atividades de inventário e de acompanhamento. A função de experimentação, destinada a confirmar ou negar as hipóteses explicativas provindas da avaliação-diagnóstico, é a de identificar combinações técnicas mais adaptadas e melhor dominadas.

Em uma operação de Pesquisa-Desenvolvimento tanto a inovação como a apropriação são objetos de pesquisa. Assim, os objetivos da Pesquisa-Desenvovimento 
no meio rural, são (DUFUMIER, 1985; PILLOT, 1984): detectar os principais fatores e condições limitantes da produção agrícola, hierarquizá-los, pesquisar e experimentar localmente as proposições de solução; e, verificar as condições de apropriação das inovações propostas, condição para difundi-las para um maior número de agricultores.

Finalmente, a Pesquisa-Desenvolvimento se configura como um método de conhecimento e ação no meio rural, que se caracteriza por utilizar a abordagem sistêmica para apreender os diferentes níveis de organização da produção agrícola , ser pluridisciplinar, isto é , integra as análises de diferentes disciplinas entorno de um objeto complexo comum e, se interessar pelas dinâmicas contraditórias do desenvolvimento agrícola, pelas evoluções passadas e as possibilidades do futuro.

\subsubsection{A abordagem sistêmica : uma metodologia de estudo e representação de fenômenos complexos}

O progresso alcançado em vários campos científicos, a partir dos anos 50, fez emergir uma nova maneira de observar e compreender a atividade humana, que recebeu as mais diversas denominações: análise sistêmica, análise de sistemas, abordagem sistêmica, também denominada de análise estrutural, análise funcional.

A abordagem sistêmica, segundo BONNEVIALE et alii (1989) é o produto de quatro correntes científicas: a cibernética, a teoria dos sistemas desenvolvida por Bertallanfy, a teoria da informação e as ciências da modelização, em especial da modelização da decisão.

RAPOPORT (1976), destaca que o ponto de vista da teoria dos sistemas foi impulsionado pela constatação de que o método mecanicista, fundado na mecânica 
racional e estatística, era inadequado como modelo universal e, pela tendência a contrabalançar o fracionamento das ciências em especialidades isoladas uma das outras.

O procedimento analítico, derivado dos princípios da física clássica enunciados por Galileu e Descartes, teve grande sucesso em um amplo domínio de fenômenos. Propõem o estudo das partes separadamente supondo que a reunião destas constitui ou reconstitui o todo. A aplicação de tal procedimento de estudo, depende, segundo BERTALANFFY (1975), de duas condições fundamentais: as interações entre as partes constituintes da entidade ou fenômeno ou não existem ou são tão fracas que podem ser desprezadas e, em segundo lugar, que as relações que descrevem o comportamento das partes sejam lineares. A primeira condição permite que as partes possam ser esgotadas real, lógica e matematicamente, sendo em seguida reunidas. A segunda condição suporta a propriedade de aditividade, ou seja, o todo resulta da soma das partes ou os processos parciais podem ser sobrepostos para obter-se o processo total.

As condições de não interação ou de interações triviais e da similitude do comportamento das partes e do todo não são satisfeitas por fenômenos denominados de complexidades organizadas ou sistemas (RAPOPORT,1976). Um sistema é constituído de partes em interação e a sua descrição comporta um conjunto de equações diferenciais simultâneas, não lineares no caso geral (BERTALANFFY, 1975).

A abordagem dos fenômenos em termos de sistema busca essencialmente enfrentar o problema das limitações do procedimentos analíticos na ciência. $O$ procedimento sistêmico tem a intenção de abordar problemas que comparados aos problemas analíticos e somatórios da ciência clássica, são de natureza mais geral (BERTALANFFY, 1975). 
A análise sistêmica constitui-se em um novo paradigma, na acepção dada por KUHN(1987), pois põe em evidência aspectos que não eram anteriormente vistos nem percebidos, ou eram mesmo suprimidos na ciência normal e propõe um novo método para a compreensão do real.

O objetivo desta corrente teórico metodológica é o de responder a três preocupações essenciais (WALLISER ,1977):

- a intenção, em reação as tendências ultra-analíticas de certas ciências, de restaurar uma abordagem mais sintética que reconheça as propriedades de interação dinâmica entre elementos de um conjunto, que conferem a este um caráter de totalidade;

- a necessidade, para conceber e formalizar conjuntos amplos e complexos, de um método que permita mobilizar e organizar os conhecimentos com a finalidade de uma melhor adequação dos meios aos objetivos;

- a necessidade, frente a fragmentação e a dispersão do saber, de promover uma linguagem unitária que possa servir de suporte a articulação e a integração de modelos teóricos e de preceitos metodológicos dispersos em diversas disciplinas.

\subsubsection{Conceituação de sistema}

Várias definições simples de sistema são propostas por diferentes autores. De início, todos estão de acordo em designar como sistema, uma interrelação de elementos que constituem uma entidade ou unidade global. 
Becht $^{3}$, citado por HART (1980), depois de revisar vinte e quatro definições dadas na literatura para o termo sistema, usa a seguinte definição : sistema é um arranjo de componentes físicos, um conjunto ou coleção de coisas, unidas ou relacionadas de tal maneira que formam um todo.

Existem dois aspectos importantes nessas definições: a interação de elementos/componentes e a unidade global/todo que resulta. As diferentes definições acentuam um ou outro aspecto. Para BERTALANFFY (1975), o sistema é um conjunto de unidades em interação mútua. RAPOPORT (1976) salienta o traço da globalidade/totalidade, para este autor o sistema é um todo que funciona como todo em virtude dos elementos que o constituem. Para LANDRIÉRE (1984), um sistema é um objeto complexo, formado por componentes distintos, ligados entre si por um certo número de relações.

MORIN (1987) nota que um sistema não é necessária e nem principalmente composto por partes, alguns deles podem ser considerados conjuntos de estados, ou conjunto de acontecimentos, ou de reações.

Ferdinand Saussure ${ }^{4}$, citado por MORIN (1987), associa aos caracteres comuns das definições precedentes, interrelações e totalidade, uma terceira idéia, a de organização. Saussure define como sistema uma totalidade organizada, feita de elementos solidários que só podem definir-se uns em relação aos outros em função do lugar que ocupam nesta totalidade.

\footnotetext{
${ }^{3}$ BECHT, G. Systems theory, the key to holism and reductionism. Bioscience, 24 (10):574-96, 1974.

${ }^{4}$ SAUSSURE, F.de, Cours de linguistique genéral. Genebra, Payot, 1931.
} 
Na definição de sistema dada por Saussure a idéia de organização liga a idéia de totalidade a de interrelação, tornando os três termos indissociáveis. As interrelações entre componentes (elementos, acontecimentos, indivíduos...) desde que tenham um caráter regular e estável tornam-se organizacionais e produzem o sistema (MORIN, 1987).

Entretanto, resta uma última noção a incorporar em nossas diferentes definições, a de finalidade. ROSNAY (1975) define um sistema como um conjunto de elementos em interação dinâmica, organizado em função de um objetivo. O objetivo é atribuído pelo homem seu construtor e na natureza o objetivo é constatado a posteriori.

WALLISER, (1977), distingue a finalidade, propriedade revelada pelo comportamento do sistema (tudo se passaria como se...) de intencionalidade, propriedade atribuída ou imposta a um determinado sistema por um centro de decisão.

Finalmente, podemos afirmar que em um sistema, o conjunto de elementos ligados entre si por relações dinâmicas conferem a este uma organização com vistas a cumprir certos objetivos. Deste modo, um sistema é tanto um conjunto de elementos organizados como uma estrutura e esta resulta das relações que asseguram o funcionamento do sistema. Simplificadamente podemos afirmar que um sistema é uma estrutura finalizada (JOUVE, 1988).

\subsubsection{Aspectos do processo de modelização sistêmica}

O procedimento sistêmico, é um método de bem conduzir a razão, que se diferencia do "Discurso do método" de Descartes, que fundamenta o procedimento analítico. 
LE MOIGNE (1994) propõe substituir o discurso sobre o método de Descartes, pelo discurso que define o paradigma sistêmico. Para este autor os quatro preceitos do método analítico ${ }^{5}$ da evidência, da redução, da causalidade e da exaustão devem ser substituídos no discurso sistêmico pelos preceitos da pertinência, do globalismo, da teleologia e o preceito da agregação.

O preceito de pertinência consiste na concordância de que todo objeto ou fenômeno, é definido em relação as intenções implícitas ou explícitas do modelizador. Considerar sempre o objeto a ser conhecido como uma parte ativa imersa dentro de um todo maior, constitui o preceito de globalismo. Interpretar o objeto não por ele mesmo mas por seu comportamento, sem procurar explicar a priori este comportamento por alguma lei implicada em uma eventual estrutura, define o preceito teleológico. $\mathrm{O}$ preceito de agregação, de certa forma redundante em relação ao preceito de pertinência, diz que devemos concordar que toda representação do real é simplificadora, por isto é necessário buscar regras suscetíveis de guiar a seleção de agregados tidos como pertinentes (LE MOIGNE, 1994).

Estes preceitos que fundamentam o procedimento sistêmico, provocam modificações bastante radicais na atitude científica, em particular nas ciências empíricas. Passa-se de uma postura na qual a realidade é evidente e se impõe pela experiência ao experimentador ou modelizador para uma posição que afirma que a

${ }^{5} \mathrm{O}$ preceito de evidência diz que não devemos aceitar algo por verdade que não se conhece evidentemente como tal. O preceito reducionista recomenda que se examine um problema dividindo-o em partes. O preceito de causalidade recomenda que o exame das partes comece pelas dificuldades mais simples. O preceito da exaustão diz que se deve fazer enumerações em todos os sentidos as mais completas e exames gerais que possam assegurar que nada foi omitido. (DESCARTES, 1987). 
evidência e o real não tem existência independentes do espírito humano que os percebe e constrói (PIAGET,1979).

Não há verdade preexistente a qual o conhecimento sucessivamente iria descobrindo, mas o conhecimento é o resultado de um processo de construção ativa do sujeito/modelizador, portador de um projeto, em suas interações permanentes com os fenômenos que ele percebe e constrói (MORIN, 1987).

A modelização sistêmica é definida por LE MOIGNE (1994) como a ação de elaboração e de construção intencional, por composição de símbolos, de modelos suscetíveis de tornar inteligível um fenômeno complexo, e de amplificar o raciocínio do sujeito projetando uma intervenção deliberada no seio do fenômeno; raciocinando, visando principalmente, antecipar as conseqüências destes projetos de ações possíveis.

A ação de modelizar configura-se igualmente como um sistema - o sistema de modelização. Este sistema é composto pelo modelizador concebendo e interpretando o modelo de um sistema complexo, que propõe a este sua finalidade (preceito de teleologia), ou seja, a modelização sistêmica é projetiva, no sentido que inclui em seu próprio ato o(s) projeto(s) do modelizador. Para MORIN (1987), não é possível separar a observação do observador : o objeto de estudo se metamorfoseia segundo o tipo de visão que lhe é aplicado.

É nesta perspectiva que a modelização sistêmica exige não só que o observador observe a si mesmo ao observar os sistemas, mas também se esforce por conhecer o seu próprio conhecimento (MORIN, 1987). 
Conhecer um sistema complexo é sobretudo conceber o modelo que o representa, que o descreve. Compreende-se o modelo de um fenômeno ou processo, como um modo de representação tal que ele permita, de um lado, prestar conta de todas as observações feitas e, por outro lado, prever o comportamento do sistema considerado nas condições mais variadas, distintas das que deram nascimento as observações. (LE MOIGNE, 1994). A validade de um modelo advém portanto, de sua capacidade de resistir ao confronto entre as consequências por ele antecipadas e as efetivamente observadas na realidade objetiva (BROSSIER et alii, 1990).

Desta maneira, o estudo de sistemas complexos pilotados pelo homem, como no caso dos sistemas agrícolas, a experimentação em meio social, econômico e cultural real(experimentação em escala real) com a participação dos atores (agricultores, extensionistas e pesquisadores) torna-se um meio efetivo de conhecer (BROSSIER et alii, 1990).

O sistema reflete as características reais dos objetos empíricos e ao mesmo tempo é um modelo heurístico, isto é, instrumento metodológico e conceptual, que se aplica a fenômenos sem prejuízo de sua realidade. Assim, todos os sistemas, mesmo aqueles que são isolados abstratamente dos conjuntos de que fazem parte, são necessariamente enraizados na física, isto é, no real natural ou a natureza real (MORIN,1987). Pode-se falar então de sistema objeto (LE MOIGNE, 1994) ou ainda como BERTALANFFY (1975), de sistema natural.

Todo o sistema porém, mesmo o mais material, o mais fenomenicamente evidente, para existir tem necessidade do espírito humano que o isola da agitação polissistêmica da realidade. Podemos portanto, pensar o sistema do ponto de vista do sujeito. como abstração do espírito (MORIN, 1987). 
A extração, o isolamento de um sistema, depende do ponto de vista do que o observador/modelizador considera necessário em termos de autonomia e emergências ${ }^{6}$ para configurar um sistema.

Sistemas complexos, como por exemplo os sistemas agrícolas, caracterizam-se por apresentar uma grande variedade de componentes, que possuem funções especializadas, constituindo-se eles mesmos em sistemas dentro de um sistema englobante, que estão organizados em níveis hierarquicos, mantendo numerosas e diversificadas interrelações ou ligações que não são lineares.

A noção de caixa-preta introduzida por Ashby em 1956 na linguagem científica (BOURGEOIS, 1983b), é a ferramenta metodológica que permite organizar a apreensão e representação de um sistema complexo.

A caixa-preta é definida como um conjunto de elementos coordenados entre si para assegurar uma certa função, na qual há entradas (insumos) e saídas (produtos). O interessse é pelo fluxo de entrada/saída, não o processo que transforma o que entra e o que sai.

O exame de um sistema inicia por precisar os conjuntos que podem ser considerados como caixa-preta. Isto só é possível se previamente é definido uma escala de observação, o que supõe que se defina claramente porque se pretende estudar o sistema (BOURGEOIS, 1983b)..

No interior de um sistema podem ser definidos os conjuntos de elementos que numa certa escala são considerados como caixas-pretas. Caso for necessário mudar

\footnotetext{
${ }^{6}$ As emergências são as propriedadedes de um sistema que apresenta um caráter de inovação em relação às qualidades ou propriedades dos componentes considerados isoladamente ou arranjados diferentemente em um outro sistema (MORIN, 1987).
} 
de escala de observação, poder-se-á abrir a caixa-preta e examinar sua estrutura e seu funcionamento. A esta nova escala, poderá corresponder outras caixas-pretas (BOURGEOIS, 1983b).

As fronteiras do sistema são portanto, definidas pelo analista em função da lógica do funcionamento que ele procura evidenciar. Há sempre nisto algo de incerto e de arbitrário, há sempre decisão e escolha (MORIN, 1987).

Os constituintes de um sistema complexo podem ser apreendidos através de dois aspectos complementares: oa aspectos estruturais e os funcionais (ROSNAY, 1975).

Os aspectos estruturais dizem respeito a identificação da estrutura, isto é, o conjunto de regras de associação, de ligação, de interdependência, de transformação, que tendem a se identificar com a invariante formal do sistema (MORIN, 1987), ou seja, trata-se da organização no espaço dos componentes do sistema.

Aos aspectos funcionais propriamente está associada o termo sistema e é o estudo destes que permite a abordagem sistêmica ser compreensiva (JOUVE, 1986). O estudo do funcionamento de um sistema consiste em apreender as interrelações que se estabelece entre seus componentes e deste com seu ambiente, que são dependentes basicamente do tempo.

Os aspectos estruturais de todo sistema são (ROSNAY, 1975; BOURGEOIS, 1983b) :

a) limite ou fronteira, que são fixados pelo observador em função das razões pelas quais ele irá estudar o sistema;

b) elementos ou componentes, eles mesmo sistemas que podem ser agrupados em categorias, grupos, etc; 
c) reservatórios, nos quais os elementos podem ser reunidos e onde podem ser estocados energia, informações, materiais;

d) rede de comunicação, que permite as trocas de informações, de energia, de matéria, entre os elementos do sistema e entre os diferentes reservatórios.

Os aspectos funcionais de um sistema são:

a) os fluxos de energia, de informação e de matéria, expressos em quantidades por unidade de tempo. Os fluxos de energia e de materiais fazem variar os níveis dos reservatórios e, os fluxos de informações servem de base às decisões para agir sobre os fluxos de matéria e energia;

b) as comportas ou torneiras, controlam o débito dos diferentes fluxos. Cada comporta é na realidade um mini centro de decisão, recebendo informações e as transformando em ação (aumentar ou diminuir a vazão dos fluxos);

c) os tempo de resposta, resultam das diferenças de velocidade de circulação dos fluxos de diferentes tipos, dos tempos de estocagem e de esvaziamento dos reservatórios, etc;

d) os ciclos de informação, ditos ciclos de retroação (feedback) que desempenham um papel determinante no funcionamento dos sistemas. Há dois tipos de ciclos de retroação: positivos ou diretos responsáveis por toda a dinâmica de mudanças de um sistema (crescimento e evolução) e negativos ou inversos responsáveis pela regulação e pela estabilidade do sistema (restabelecimnto de equilíbrio e autoregulação). É por isto que o sistema oscila ao redor de uma posição de equilíbrio que não atinge jamais.

Para completar a descrição dos componentes de um sistema é preciso 
acrescentar as entradas e saídas que materializam as relações do sistema com o ambiente. As relações do sistema com o ambiente são mais ou menos numerosas e intensas de acordo com o tipo de sistema, mais aberto ou mais fechado.

O sistema em atividade transforma os dados de entrada em resultados de saída, o que caracteriza um processo, que tem um tempo de duração. O tempo, como visto precedentemente, comanda todos os fenômenos ligados aos aspectos funcionais do sistema. Assim, para compreender o comportamento de todo sistema, qualquer que seja a complexidade, é necessário caracterizar duas variáveis essenciais: as variáveis de fluxo que se expressam entre dois momentos e, as variáveis de estado que indicam acumulação ao longo do tempo de uma quantidade dada (ROSNAY, 1975; BOURGEOIS, 1983b).

\subsection{Os conceitos centrais da abordagem sistêmica aplicados a agricultura}

A agricultura é um processo de artificializaçao do ecossistema realizada pelo trabalho humano por meio de espécies domesticadas e selecionadas, de ferramentas e de técnicas para obter produtos agropecuários necessários principalmente para a subsistência humana (MAZOYER, 1985). Como processo, a agricultura é uma combinação finalizada, dos seguintes elementos : um material biológico, o contexto econômico e o meio ambiente, as técnicas e as práticas, as ferramentas de trabalho, situados em relação as escalas de tempo e de espaço (BONNEVIALE et alii, 1989).

Percebida desta forma pode-se dizer que o processo de produção agrícola mobiliza quatro tipos de componentes básicos : humanos, mecânicos, edáficos e biológicos. Niveis de integração destes componentes são distinguidos, indo do mais simples, a operação técnica, ao mais complexo o sistema agro-alimentar mundial (MAZOYER, 1985). 
O termo genérico sistemas agrícolas é usado para designar o conjunto de noções e conceitos correspondentes aos níveis de organização da atividade de produção agrícola (MAZOYER, 1985; DEFFONTAINES, 1988). A cada nível organizacional, é designado um termo que é igualmente o conceito de funcionamento deste nível e que corresponde, em primeira aproximação a unidades territoriais particulares (JOUVE, 1986), ou centros de decisão (BOURGEOIS, 1983b).

Desta maneira, distinguem-se :

a) o nível dos processos produtivos - é onde se observam e se deduzem os mecanismo biológicos, de intervenção dos equipamentos e das técnicas, ou seja as parcelas cultivadas e os rebanhos;

b) o nível do estabelecimento agrícola e a família - que diz respeito a combinação, no sentido exato da palavra, de processos produtivos, que devem ser compreendidos em relação ao trabalho disponível e mobilizado, ao capital, aos resultados quantitativos e qualitativos do conjunto da atividade das pessoas envolvidas;

c) o nível da região englobante - que comporta a atividade economica a jusante e a montante dos níveis precedentes.

Ao nível da unidade de produção correspondem os conceitos de sistema de produção e de sistema família-estabelecimento. No seio da unidade de produção estâo as parcelas e as criações animais, a que correspondem os conceitos de sistema de cultivo e o de sistema de criação. O conceito de sistema forrageiro associa a parcela cultivada às criações. $O$ estabelecimento agrícola encontra-se imerso em uma região que é apreendida através do conceito de sistema agrário (MAZOYER, 1985; JOUVE, 1986; FRESCO, 1984; PILLOT, 1989). 


\subsubsection{O conceito de sistema agrário}

O sistema agrário é muitas vezes definido, a escala regional, como a associação de atividades produtivas e de técnicas utilizadas por uma sociedade visando satisfazer suas necessidades. Exprime em particular a interação entre um sistema bioecológico representado pelo meio natural e um sistema sócio cultural através de práticas resultantes do progresso técnico (VISSAC, 1979).

Esta definição esta bastante centrada sobre a idéia de sociedade rural e o território que esta explora em um determinado momento. O Departamento Sistemas Agrarios e Desenvolvimento do INRA, utiliza um conceito que vai na mesma direção, restringindo sua aplicaçao até no maximo a pequena região. Assim, o sistema agrário é definido como um território rural restrito, onde uma população exerce grande parte de sua atividade e as relações que se estabelecem no seio desta população ao explorar o meio em um determinado contexto sócio econômico (INRA-SAD, 1985).

MAZOYER (1985), por outro lado, amplia o conceito. Para este autor o conceito de sistema agrário deve ser empregada para caracterizar e avaliar as transformações que afetam a longo prazo o conjunto ou um conjunto dominante de estabelecimentos agricolas de uma região ou pais e para compreender as condiçoes e consequências econômicas e culturais implicadas em suas evoluções e em suas diferenciações. Deste modo, MAZOYER (1985) define o sistema agrário como um modo de exploração do meio historicamente constituído e durável, um sistema de forças de produção adaptado às condições bioclimáticas de um espaço determinado e respondendo às condições e às necessidades do momento. As variáveis essenciais que 
conformam o sistema agrário, são: o meio cultivado, os instrumentos de produção, o modo de artificialização do meio, a divisão social do trabalho entre agricultura e os outros setores econômicos, o excedente agrícola, as relações de troca, enfim o conjunto de idéias e instituições que permitem garantir a reprodução social.

JOUVE (1986) nota que o conceito de sistema agrário é muito mais operatório para analisar a atividade agrícola de sociedades que artificializaram pouco o meio - baixo grau de mecanização, restrição para investimentos que permitam influir sobre a s condições climáticos, etc.

\subsubsection{Do sistema de produção ao sistema família-estabelecimento}

Os agroeconomistas passaram a utilizar o conceito de sistema de produção para fins de pesquisa operacional e programação linear no inicio da década de 60. A idéia de interrelação entre elementos se expressa na definição dada por Chombart de Lauwe et alii', citado por MAZOYER (1985). O sistema de produção é a combinação das produções e dos fatores de produção no estabelecimento agrícola.

Os componentes do sistema são eles mesmo sistema. Assim, MAZOYER (1985) define sistema de produção como sendo a combinação de sistemas de cultivo e de sistemas de criação simples, conduzidos nos limites permitidos pelo aparelho de produção

Ao final dos anos 60 a definição de sistema de produção passa a ser associada muito mais a de funcionamento do estabelecimento rural. Sebillotte em 1968

\footnotetext{
'CHOMBART DE LAUWE, J. ; POITEVIN, J. ; TIREL, J.C. Nouvelle gestion de exploitations agricoles. Paris, Dunod, 1963. 507p.
} 
considerou que a estabelecimento é uma estrutura na qual o que importa são os mecanismos que permitem sua autorregulação (BOURGEOIS 1983b).

As combinações de fatores e de produções estão organizadas com vistas a alcançar um objetivo. TOURTE (1978) considera o sistema de produção como o conjunto de produções vegetais e animais, e de fatores de produção, terra, trabalho e capital, gerido pelo agricultor com vistas a satisfazer seus objetivos sócio-econômicos e culturais ao nível do estabelecimento agrícola.

O estabelecimento agrícola é composto de dois subsistemas em interação: um que comportaria a racionalidade do agricultor (objetivos, decisões, organizações) e outro que comportaria as características do meio de produção e os fatores externos que condicionam a produção. A interação destes dois subsistemas constitui o sistema de produção (SEBILLOTTE, 1981).

O funcionamento do sistema de produção é o resultado de um encadeamento de decisões. Quando é referido a unidade familiar de produção.significa dizer que as decisões são tomadas no seio de uma família, vivendo ao menos em parte, da produção agrícola, e que em termos de orientação do financiamento, do emprego do tempo, a família e o sistema de produção não são independentes (BOURGEOIS, 1983).

Para DAMAIS (1987) o sistema de produção é constituído pelo par estabelecimento mais a família. O estabelecimento é o conjunto de meios de produção sobre os quais o produtor pode atuar através de suas decisões.

Esta distinção entre família e o estabelecimento pode ser interessante para estudos regionais. O conceito de sistema estabelecimento se refere a combinação das atividades produtivas de bens e serviços agrícolas e não agrícolas, operacionalizadas 
no seio do estabelecimento, bem como a natureza das relações com o ambiente que daí resultam (BONNEVIALLE et alii, 1989).

O sistema de produção no entanto, não está isolado, pelo contrário está imerso em um contexto social econômico e ecológico, com o qual mantém interrelações que condicionam as escolhas e o seu funcionamento (BOURGEOIS ,1983b).

CAPILLON \& SEBILLOTTE (1980) consideram o estabelecimento agrícola, ou melhor o par família-estabelecimento, como um sistema finalizado pelos objetivos da família ( necessidades, nível de renda visado, modo de vida desejado), confrontado a um conjunto de condicionantes internos e externos.

BONNEVIALLE et alii (1989), notam que a utilização do conceito de sistema de produção está associado, seja a consideração de que o estabelecimento agrícola se confunde com a unidade de produção, seja por privilegiar no seio do estabelecimento o estudo da máquina produtiva, quer dizer o processo produtivo e de suas combinações. É corrente ainda associar este conceito aos termos de performances, de produtividade, de intensificação, ou de extensificação, e de distinguir no seio do sistema de produção os subsistemas relacionados entre si : sistema de cultivo, sistema forrageiro e sistema de criação. Estes autores propõem, integrando a evolução conceptual havida, que o sistema estabelecimento agrícola pode ser decomposto em vários sistemas, tomando por base o modelo da forma canônica do sistema-organização proposto por LE MOIGNE (1988 e 1990). Estes subsistemas são: o sistema de operação ou sistema de produção, o sistema de decisão e o sistema de informação.

O sistema de operações ou de produção tem a função de por em prática o conjunto de operações necessárias à gestão dos processos produtivos: gestão dos fluxos 
de matéria, de trabalho, de equipamentos, de moeda, e de informações, que o estabelecimento importa ou retém, estoca, transforma, ou transporta e que ele exporta ou restitui ao meio ambiente.

Ao sistema de decisão cabe a função de gerar as decisões que irão orientar e assegurar o comando do sistema de operação em função das finalidades e objetivos de condução.

O sistema de informação tem por função assegurar a ligação do sistema de decisão com o sistema de operação, é ele que produz as informações em benefício do sistema de operação e que permite ao sistema de decisão controlar os processos produtivos e suas combinações no seio do sistema de operação.

Como a família é o pólo unificador e portanto sustentador do projeto de objetivos, a denominação mais corrente atualmente é de Sistema famíliaestabelecimento (BONNEVIALLE et alii, 1989).

\subsection{Sistema de cultivo : um conceito operatório da agronomia}

No século XVII a idéia de sistema de cultivo confundia-se com o código ou princípios que regiam a condução de uma cultura. Tinha sentido em uma época em que os conhecimentos agronômicos eram escassos e os progressos técnicos lentos (SEBILLOTTE,1984).

A partir do século XIX, tanto a evolução técnica como dos conhecimentos fisiológicos e agronômicos permitiram aos agrônomos precisar o conceito de sistema de cultivo. O conde de Gasparin em seu Curso de Agricultura propôs a seguinte definição: "A escolha que o homem faz de como explorará a natureza, 
seja deixando-a livre, seja dirigindo--a com maior ou menor intensidade nos diferentes sentidos é o que nós denominamos sistema de cultivo, e se pretende que esta definição compreenda o conjunto de operações agrícolas que constituem uma exploração, e a natureza dos meios físicos e mecânicos que utilizamos, seja para fazer crescer, colher e utilizar os vegetais (SEBILLOTTE, 1984).

A definição proposta por de Gasparin ultrapassa a agronomia no sentido estrito, pois inclui aspectos relacionados a economia e se aproxima da noção de sistema de produção. Para classificar os sistemas cultivos, ele utiliza no entanto, essencialmente critérios baseados na manutenção da fertilidade do solo e por esta razão o conceito estaria no âmbito da agronomia (SEBILLOTTE, 1984).

A ênfase da definição de Gasparin está na gestão do espaço agrícola explorado por uma unidade de produção, o estabelecimento agrícola, excluindo assim o campo de aplicação do conceito os espaços mais amplos como a região.

Ao longo do século XX, as técnicas agronômicas evoluíram muito, assim como as condições econômicas. Os meios que se dispõe, sobretudo a partir da segunda grande guerra, permitem que se possa dizer que não só há várias técnicas para alcançar um resultado determinado, senão que os objetivos dos agricultores são muito mais variados e as condições sócio-econômicas da produção também são mais variadas que no passado (SEBILLOTTE, 1978)

A definição proposta em 1975 por um grupo de trabalho do INRA e INA-PG, sintetiza esta evolução : o sistema de cultivo é o subconjunto do sistema de produção, definido para uma superfície de terreno tratado de maneira homogênea, pelas culturas com sua ordem de sucessão e os itinerários técnicos praticados (SEBILLOTTE, 1982; SEBILLOTTE, 1984). 
A definição de itinerário técnico, introduzida por Sebillotte é original, consistindo na combinação lógica e ordenada de técnicas culturais que um agricultor aplica sobre uma determinada parcela com a finalidade de atingir seus objetivos (SEBILLOTTE, 1982).

No que se refere as sucessões de culturas é necessário distinguir as noções de efeito precedente, efeito acumulativo e sensibilidade da cultura seguinte.

O efeito precedente, se define, para uma parcela, como a variação dos estados do meio (biológicos, físico e químicos) entre o princípio e o fim do cultivo considerado, sob a influência conjunta da população vegetal e das técnicas aplicadas, ambos submetidos as influências climáticas (BOURGEOIS, 1985; SEBILLOTTE, 1990)

O efeito acumulativo é o efeito resultante, em um período de vários anos, dos efeitos precedentes, sua soma algébrica, por assim dizer (BOURGEOIS, 1985; SEBILLOTTE, 1990).

Sensibilidade do seguinte, se define pela amplitude das reações da cultura a diversidade dos estados do meio criados pela cultura que a precedeu, sob a ação de um clima determinado e tomando em conta o itinerário técnico utilizado sobre o seguinte.

A definição de sistema de cultivo precedentemente enunciada permite diferenciar o conteúdo recoberto por outras acepções do termo. Os economistas utilizam a denominação sistema de cultivo para caracterizar a combinação de cultivos e o grau de utilização dos meios de produção em um conjunto de estabelecimentos. Os geógrafos, igualmente, utilizam o termo para descrever e classificar a utilização do território regional e analisar a paisagem (AUBRY, 1990). Esta definição insiste no enfoque ao nível do estabelecimento agrícola, como já propunha de Gasparin. Supõe-se 
que em um mesmo estabelecimento possam existir mais que um sistema de cultivo e que esta variabilidade é um ponto central de interesse para o agrônomo. Aos economistas interessa a comparação entre unidades de produção e/ou das regiões agrícolas em relação a disponibilidade de fatores de produção, quer dizer ao nível do sistema de produção. Ao agrônomo, segundo AUBRY(1990) o que interessa é entender as interrelações entre populações vegetais, meio e técnicas, de tal maneira, que o permita considerar as evoluções e influências que atuam sobre a elaboração do rendimento de cada cultivo e a evolução do meio.

Ainda que a definição dada em 1975 tenha conseguido precisar o enfoque estritamente agronômico do conceito, a definição adotada foi em geral utilizada em um sentido de descrição dos ecossistemas, especialmente no que se refere a utilização do solo e a formação da paisagem.

SEBILLOTTE (1990), salienta que a definição deveria enfocar as maneiras de cultivar as parcelas e suas repercussões sobre a elaboração do rendimento e a evolução das características do meio. Por isto, propôs a seguinte definição : um sistema de cultivo é o conjunto das modalidades técnicas utilizadas sobre parcelas tratadas de maneira homogênea. Cada sistema de cultivo se define pela natureza das culturas e sua ordem de sucessão, pelos itinerários técnicos aplicados a estas diferentes culturas, o que inclui a escolha das variedades para as culturas em consideração.

Esta definição apresenta as seguintes características : diz o que é o sistema de cultivo, não apenas o que o define, preocupa-se diretamente com o manejo técnico em relação a elaboração dos rendimentos e as evoluções do meio e enfatiza que há itinerários técnicos para cada um dos cultivos. 


\subsubsection{Os conceitos de sistema de criação e de sistema forrageiro}

O conceito de sistema de criação é pouco preciso, podendo referir-se tanto ao projeto como ao nível ao qual o projeto se aplica.

Enquanto projeto, o sistema de criação é definido por LANDAIS et alii (1987) como um conjunto de elementos em interação dinâmica organizados pelo homem com a finalidade de transformar, por intermédio dos animais domésticos, determinados recursos em produtos (leite, ovos, couro, dejeções, etc) ou para responder a determinadas necessidades (tração, lazer, etc). Os componentes deste sistema são: o agropecuarista e suas práticas; os animais domésticos agrupados em lotes, ou tropas, ou ainda populações; e os recursos (alimentos, espaço, trabalho ou dinheiro) consumidos e transformados por estes animais.

O sistema de criação é definido também em função do nível de organização da produção a que está referido. Ao nível interno da unidade de produção, o sistema de criação é definido como o conjunto de setores produtivos e de técnicas que permitem produzir animais ou produtos animais em conformidade aos objetivos do agropecuarista e submetidos aos condicionantes do estabelecimento (MENJON \& D’ORGEVAL, 1983). Em seu emprego a um espaço mais amplo, a região, o sistema de criação é um dos dois componentes de um sistema de produção (o outro é o sistema de cultivo), definido como um modo de combinação de terra, forças e meios de trabalho visando a produção animal, comum a um conjunto de estabelecimentos (JOUVE, 1992).

Em um estabelecimento, o sistema de criação é constituído muitas vezes de mais de um setor. Por exemplo, maternidade e recria no caso de suínos; engorda de novilhas e vacas em lactação na bovinocultura leiteira. Estes setores estão ligados um ao 
outro pelos fluxos de animais e cuja avaliação deve levar em conta o conjunto da atividade de exploração pecuária.

A definição do termo sistema forrageiro não está ainda bem fixada (BONNEVAL, 1993).

Para ATTONAY (1980) o sistema forrageiro pode ser definido como o conjunto de meios de produção, de técnicas e de processos de transformação, em um determinado território, tendo por função assegurar a correspondência entre o(s) sistema(s) de criação(ões) e o(s) sistema(s) de cultivo.

Há autores como DELORME et alii (1983) e DURU et alii (1988) que consideram que o sistema forrageiro não é um conjunto produtivo mas um conjunto regulador controlado pelo agricultor. O sistema forrageiro é essencialmente um sistema de informação e de decisão cuja tarefa na atividade pecuária, é assegurar a correspondência entre as produções e necessidades de dois sistemas, o sistema de cultivo e o sistema de criação respectivamente, de acordo com os objetivos e as condições de funcionamento da atividade pecuária.

Fazer um diagnóstico de um sistema forrageiro significa portanto, avaliar como é feita a regulação (maneira com que o sistema reage as perturbações de seu ambiente) entre produção, compra, venda, estocagem de forragens e necessidades animais e como esta pode ser melhorada.

\subsection{O diagnóstico do estabelecimento agrícola}

A Pesquisa-Desenvolvimento, como anteriormente visto, modifica a perspectiva das intervenções da engenharia agronômica, colocando o diagnóstico da 
situação a transformar como condição preliminar a toda atividade de pesquisa e de desenvolvimento.

Por definição o diagnóstico é um julgamento realizado em um certo intervalo de tempo, sobre uma situação ou um estado visando guiar a ação (JOUVE, 1992).

Para julgar é necessário inicialmente compreender, quer dizer, o julgamento é precedido de uma fase de análise da situação. A situação não é somente um quadro no qual será instalado a pesquisa e no qual serão interpretados os resultados, é também o terreno no qual o resultado da investigação vai receber o veredicto de sucesso ou fracasso, indica portanto sua aceitação social (LEGAY, 1988).

1 O estabelecimento agrícola está no centro de toda reflexão e procedimento de diagnóstico, pois é onde se dá o processo de artificialização do ecossistema e é a célula básica do processo de produção agrícola (DUMAZERT \& LÉVARD, 1987) : é o lugar onde se intercruzam elementos bio-técnicos e sócioeconômicos, sob a direção de um centro de decisão o agricultor e sua família (BOURGEOIS, 1983b; DUFUMIER, 1985; SAUTTER, 1985); é onde se hierarquizam os problemas técnicos (SEBILLOTTE, 1979) e se refletem as iniciativas de desenvolvimento comandadas ao nível do sistema sócio-econômico englobante.

Em um mesmo território coexistem unidades de produção diferentes umas das outras, seja por suas estruturas (o tamanho, capital, instalações, etc), ou em sua lógica de funcionamento (o uso de insumos, o papel das atividades produtivas, a disponibilidade de trabalho, etc). Para o engenheiro agrônomo a diversidade das unidades de produção se manifesta pela variedade de respostas dos agricultores às ações de 
de desenvolvimento ou pelos diferentes modos da utilização agrícola de um mesmo meio natural (CAPILLON, 1985), ela é pois evidente. Para representar esta diversidade de uma forma operacional recorre-se a uma classificação, a modelização tipológica.

\subsubsection{As práticas : objeto central do diagnóstico}

O estudo da atividade agrícola a partir e em torno do seu nível mais elementar, o estabelecimento agrícola, tem na noção de fato técnico seu fio condutor. A análise do fato técnico em uma situação particular encontra na definição de prática do agricultor um conceito mais operante (GRAS et alii, 1989). Assim, é através da análise das práticas dos agricultores que se busca apreender e explicar a diversidade de maneiras com que são operacionalizadas as combinações produtivas e as técnicas culturais na unidade de produção (MILLEVILLE, 1987; CAPILLON, 1988), o que permite adequar os conselhos de gestão e de proposições técnicas de melhoria.

O interesse pelas práticas dos agricultores está associado ao fato de que elas são reveladoras: dos objetivos de produção, das atividades produtivas prioritárias do agricultor, das potencialidades e limitações relacionados a heterogeneidade de solos ou do rebanho; da tecnicidade do agricultor; das referências técnicas utilizadas e da percepção que o agricultor tem dos condicionantes de seu estabelecimento (CAPILLON, 1986). Para LANDAIS \& DEFFONTAINES(1990), fundamentalmente, o interesse em descrever e analisar as práticas está ligada a posição central do homem na unidade de produção vista como um sistema. 
Para TESSIER (1978) as práticas agrícolas são as atividades elementares, as maneiras de fazer em uma ótica de produção. Para MILLEVILLE (1987), trata-se das maneiras concretas de agir dos agricultores.

A noção de prática pode ser melhor definida em oposição a de técnica (LANDAIS \& DEFFONTAINES, 1990). Uma técnica é um conjunto ordenado de operações, tendo por finalidade a produção, podendo ser baseada tanto em conhecimentos científicos, como em conhecimentos empíricos, ou ainda, e este é o caso mais freqüente entre os agricultores, na combinação dos dois (TESSIER, 1979). Enquanto as técnicas podem ser descritas independentemente do agricultor que as operacionaliza, as práticas por outro lado, estão ligadas ao operador e às condições nas quais este realiza seu trabalho (MILLEVILLE, 1987).

A prática é de ordem da ação, enquanto que a técnica é da ordem do conhecimento (DEFFONTAINES \& PETIIT, 1985). A técnica é um modelo conceitual, pois pode ser descrita em abstrato, sem referência a uma situação particular, o que a torna transmissível. Ao contrário, a prática se enraíza em um contexto particular situado no espaço, e no tempo, é dimensionada (MILLEVILLE, 1987). Interessar-se pela prática significa construir um projeto sobre um contexto preciso, este é o caso de quem se interessa pela gestão da unidade de produção (LANDAIS \& DEFFONTAINES, 1990).

A prática portanto, não pode ser reduzida as regras técnicas, ou a localização das técnicas, mas é o resultado das escolhas do agricultor, de uma decisão que este toma em função de seus objetivos e de sua situação (MILLEVILLE, 1987; LANDAIS \& DEFFONTAINES, 1990).

Tributárias do funcionamento do estabelecimento agrícola em seu 
conjunto, as práticas são portanto personalizadas, indexadas a um sistema de produção particular. É por esta razão, que quando se estuda a unidade de produção como um sistema pilotado pelo homem as práticas são o objeto central do diagnóstico (LANDAIS \& DEFFONTAINES, 1990; MILLEVILLE, 1987)

Entre práticas e técnicas existem relações recíprocas, do saber ao fazer, colocar uma técnica em prática, e do fazer ao saber, tirar das práticas os ensinamentos técnicos, que são cruciais para o processo de desenvolvimento.

Colocar em prática uma técnica no entanto, como sublinha TESSIER (1978), não é jamais uma passagem unívoca, repetível, pelo contrário, é sempre uma passagem única. Isto porque a técnica deverá a cada vez que for realizada inserir-se em um sistema cuja complexidade o torna único.

A relação inversa, das práticas às técnicas, não resulta de uma simples operação de memorização, porém de uma operação de objetivação e construção de uma referência técnica reutilizável e passível de difusão. Esta operação supõe um tratamento prévio da informação, o que depende por sua vez da natureza dos indicadores utilizados e do referencial preexistente. É esta a razão que faz com que observadores diferentes tirem ensinamento diversos da observação da mesma prática (LANDAIS \& DEFFONTAINES, 1990), o que vem a ser interessante para o progresso técnico da agricultura.

Nem toda ação pode ser qualificada de prática. LANDAIS \& DEFFONTAINES (1990) ressaltam que não há prática se não há atividade voluntária, o querer fazer do agricultor. Este postulado de intencionalidade conduz a uma regularidade , a uma repetibilidade das práticas no tempo e no espaço, ou seja, das 
regras de decisão. O pressuposto é que há uma certa estabilidade em um tempo determinado das estruturas de produção e das referências técnicas do agricultor e dos condicionantes externos de suas decisões.

Um outro aspecto relacionado a definição das ,práticas é o de seu dimensionamento. Entre o conjunto de atividades feitas pelo agricultores podemos facilmente distinguir as atividades que são atos elementares, como por exemplo a regulagem de um arado ou lavagem dos tetos das vacas antes da ordenha, e atividades mais globais, como a ordenha ou o preparo do solo. Por isto LANDAIS \& DEFFONTAINES (1990), caracterizam o conceito de prática como um conceito de geometria variável, isto é, a dimensão da prática a ser analisada depende do ponto de vista adotado e dos objetivos buscados em seu estudo.

O estudo das práticas comporta dois momentos: a observação/descrição e a compreensão/análise (JOUVE, 1992).

A observação e descrição das práticas é a condição preliminar elementar para sua análise. A descrição geralmente pode ser feita através de enquete. Convém contudo sublinhar que a enquete não pode se limitar a entrevista verbal do agricultor, ela requer observações diretas (MILLEVILLE, 1987). A confrontação sistemática entre o dito e o observado, além de permitir uma melhor descrição permite ainda esclarecer a percepção que os agricultores tem de sua situação e de seus objetivos.

A análise das práticas pode ser feita de duas maneiras complementares, segundo CAPILLON (1087): a análise interna, do ponto de vista dos agricultores, e a análise externa, feita pelos técnicos, que permite analisar a eficácia destas práticas.

A primeira consiste em analisar as razões que levam o agricultor a adotar 
esta ou aquela prática. Trata-se, de examinar a racionalidade do agricultor, subjacente as suas práticas.

A segunda forma de analisar as práticas, visa avaliar suas performances ou sua eficácia, avaliação que só pode ser feita em relação a um objetivo, geralmente ligada a um ponto de vista disciplinar. Assim, as performances produtivas serão analisadas pelos engenheiros agrônomos através dos rendimentos, ao economista interessará o valor agregado pela prática examinada e por sua vez o ecólogo se interessará pelos impactos ambientais. É este caráter contingente da avaliação das práticas que nos levam a relativisar todo julgamento das práticas e por outro lado reforça a necessidade da pluridisciplinaridade (JOUVE,1992).

LANDAIS \& DEFFONTAINES (1990) propõem abordar o estudo das práticas por três vias distintas porém complementares: modalidade, eficácia e oportunidade.

A ótica da modalidade visa identificar as práticas observadas privilegiando o aspecto descritivo. Para além da identificação do objeto de ação, o que interessa mesmo é maneira de fazer. A descrição destas maneiras permite qualificar o saber-fazer do agricultor. Estes autores acrescentam que o estudo da modalidade de uma prática em uma determinada unidade de produção pode ampliar o campo de investigação em diversas direções : o estudo do conjunto das práticas realizadas nesta unidade de produção; o estudo da diversidade das modalidades da prática em questão em um conjunto de estabelecimentos, situados em uma região; o estudo da evolução das práticas no tempo.

A questão da eficácia conduz a análise em direção aos subsistemas, pois 
trata de examinar os resultados da ação do agricultor. Estes resultados podem ser classificados em efeitos e conseqüências. Os efeitos estão relacionados aos objetivos mensurados da execução da prática em si. As conseqüências dizem respeito as repercussões sobre o sistema englobante do objeto que recebeu a ação.

Os efeitos das práticas são julgados segundo um ponto de vista experimental e analítico, desconsiderando o contexto real da execução da prática. As conseqüências por seu turno só podem ser avaliadas a partir do estudo da estrutura e do funcionamento do sistema considerado. CAPILLON (1988) salienta que o estudo das práticas e sobretudo o seu julgamento pelo pesquisador ou extensionista deve ser restituído no contexto mais amplo do funcionamento da unidade de produção para ter um valor em matéria de desenvolvimento.

O aspecto da oportunidade está relacionado ao sistema decisional. Tratase portanto de esclarecer os determinantes da operacionalização de uma prática determinada, em um dado momento, referidos ao projeto do agricultor e ao conjunto da sistema gerido pelo agricultor em uma perspectiva de soluções satisfatórias (LANDAIS \& DEFFONTAINES, 1990)

\subsubsection{A abordagem global do estabelecimento agrícola}

A formalização de um método de estudo do sistema famíliaestabelecimento originou o que se denomina de abordagem global do estabelecimento agrícola (BONNEVIALE et alii, 1989).

A abordagem global se contrapõe aos diagnósticos setoriais. Este são assim denominados por cindirem o estabelecimento em setores, produções e atividades, 
cujas performances são julgadas independentemente do contexto geral do estabelecimento. Do ponto de vista da geração do conhecimento admite-se que a cada sujeito e disciplina corresponde apenas um só setor/objeto - a criação é domínio do zootecnista, a produção vegetal do agrônomo, etc. O corolário desta atitude é um discurso no qual a norma predomina misturada com a lógica de quem a prescreve (BOURGEOIS, 1983a).. É a base da visão tecnicista da agricultura.

Há dois textos representativos desta formalização, o de CAPILLON et alii (1975) e de OSTY (1978). Para CAPILLON et alii (1975) o estabelecimento agrícola pode ser assimilado como um sistema cuja evolução está submetida as decisões dos agentes deste sistema, os agricultores. OSTY(1978) acrescenta: o estabelecimento agrícola é um todo organizado que não responde a critérios simples e uniformes de otimização e é a partir da visão que os agricultores tem de sua situação que podem-ser compreendidas suas decisões e necessidades.

A abordagem global do estabelecimento agrícola. é portanto, a abordagem do seu funcionamento, o que comporta dois componentes de estudo : os fluxos e transformações e as decisões (SEBILLOTTE, 1979; BOURGEOIS, 1983b).

Para BONNEVIALE et alii (1989) a abordagem global, é o estudo do complexo de decisões e de ações produzidas por pessoas, indivíduos ou grupos, agindo em um ambiente com vistas a satisfazer as finalidades fixadas para este estabelecimento. Este estudo comporta dois componentes : o estudo dos fluxos e transformações que ocorrem no interior do estabelecimento e entre este e o ambiente, de uma parte, e de outra parte o estudo das decisões do agricultor e sua família.

A avaliação da eficiência das transformações, da reprodutibilidade do 
sistema de produção e a capacidade deste em atender as expectativas da família ou do proprietário fazem parte também do diagnóstico do funcionamento do estabelecimento agrícola.

O diagnóstico do funcionamento está fundado em dois princípios chaves : o estabelecimento agrícola é visto como um sistema e os agricultores tem razões de fazer o que fazem (BONNEVIALE et alii, 1989).

\subsubsection{Considerações sobre o estudo do estabelecimento agrícola como um sistema}

O estabelecimento agrícola pode ser considerado um sistema pois resulta das múltiplas relações dos elementos que o conformam. Os elementos deste sistema são: insumos, produtos de consumo intermediário, produtos de bens e serviços e subprodutos sejam eles consumidos, estocados ou transformados no interior do sistema, ou deslocados para fora, meios de produção que são as parcelas, os animais, as construções, as máquinas e equipamentos, a força de trabalho física e intelectual e o dinheiro.

1/ DAMAIS (1987) distingue os elementos do sistema de produção em elementos de ordem estrutural e de ordem variável. A superfície do estabelecimento, o capital disponível, fixo e circulante, e a mão de obra são de ordem estrutural, enquanto os tipos de atividades de cultivo e de criação são de ordem variável.

O sistema de produção resulta das múltiplas interações entre os diferentes processos produtivos que ocorrem ao nível do estabelecimento agrícola. Estas interações se manifestam ao nível (DAMAIS, 1987; BONNEVIALE et alii, 1989) : do uso dos meios de produção; das associações entre agricultura e pecuária; das associações de 
cultivo; das rotações de culturas; das ligações estreitas entre meios de produção disponíveis e produções agropecuárias escolhidas.

O sistema de produção apresenta um período de funcionamento que se repete ciclicamente no tempo. A amplitude do ciclo é determinado pelo ritmo biológico que rege a produção agropecuária do estabelecimento, em geral este período é de um ano. Durante este período, o agricultor combina os meios de produção disponíveis no estabelecimento para realizar um processo produtivo dado, que se materializa em certas atividades agrícolas e pecuárias (combinação de produções).

$\mathrm{O}$ conjunto de atividades agrícolas e pecuárias realizadas no estabelecimento durante o período de funcionamento do sistema, é um conjunto estruturado e coerente, é o resultado de um processo de tomada de decisões de parte do agricultor, quanto aos diferentes tipos de cultivos que irão ser realizados, as áreas dedicadas a cada uma delas, a quantidade de insumos empregada em cada atividade, o tipo de rotação dos cultivos escolhidos,etc. A coerência está na relação entre as finalidades e o funcionamento ( SEBILLOTTE, 1979; DUFUMIER, 1985).

Esta coerência interna do sistema de produção não implica que não haja concorrência entre vários subsistemas (sistema de cultivo, sistema de criação, sistema forrageiro) no interior do sistema de produção. Pelo contrário, é justamente a existência de concorrência entre subsistemas que ocupam certos meios de produção presentes em quantidades limitadas no estabelecimento que criam a necessidade de coerência interna (DAMAIS, 1987).

A coerência interna está relacionado ao ciclo de funcionamento, que no entanto ao longo do tempo pode apresentar contradições, exigindo sua atualização. 
Assim por exemplo, um determinado sistema de cultivo pode ter efeitos acumulativos não esperados, que determinam modificações no manejo e no tipo de produção, ou ainda a sobra de cultivo (resteva) pode provocar a inclusão da engorda de gado, etc.

As interrelacões e interacões se organizam através dos fluxos e estes devem ter uma certa constância no tempo para que um sistema de produção se constitua (BOURGEOIS, 1983b; DAMAIS, 1987). Os fluxos são os movimentos entre os elementos, de matéria, trabalho, de dinheiro e de informação, sobre os quais o agricultor toma decisões.

As interrelações e interações identificadas em um sistema não são portanto produto do acaso, mas o resultado de uma ou várias decisões do produtor. A coerência interna do sistema de produção é também a coerência do conjunto de decisões sucessivas que o agricultor toma em seu estabelecimento. A existência desta coerência interna permite compreender por que certas decisões do agricultor, consideradas isoladamente do conjunto podem ser consideradas ilógicas, ou errôneas, quando ao contrário, podem ser necessárias ao funcionamento do conjunto do sistema.

Para assegurar uma certa estabilidade o sistema de produção necessita de mecanismos de regulação. Assim a diversificação seja de cultivos, seja de manejo técnico, pode ser a base de uma estratégia para conter os efeitos de imprevistos. A operacionalização desta estratégia, no entanto pode diferir muito de um agricultor a outro.

Por outro lado, estas interações condicionam o grau de complexidade do sistema e amplitude das reações que se desencadeiam quando se pretende transformar o sistema ou quando este é perturbado por uma ocorrência nova. 
O sistema de produção como foi dito acima é cíclico. Isto implica a existência de uma reprodução do sistema de produção, reprodução que permitiria teoricamente, no ano seguinte a repetição do processo de produção em condições semelhantes.

O sistema família-estabelecimento é um sistema aberto, isto é, mantém interrelações mais ou menos intensas e numerosas com o meio em que está inserido. Este meio, é caracterizado como metassistema, podendo-se distinguir o sistema agrário e mais em geral o sistema sócio econômico e o meio ambiente (BOURGEOIS, 1983b).

Este meio que interage com o sistema influi necessariamente sobre o modo de reprodução do sistema, já que é parte, assim como os meios de produção disponíveis no estabelecimento, das condições nas quais se realiza a reprodução (condições que são específicas em um momento histórico dado), do sistema.

Frente aos condicionantes internos e externos o agricultor adota uma atitude lógica, racional, que se traduz em optar pelas combinações de atividades que irão permitir alcançar de melhor forma possível a reprodução do sistema famíliaestabelecimento, sendo dados os meios de produção, o meio sócio-econômico e ecológico. Esta atitude é denominada de racionalidade econômica do agricultor (DUFUMIER, 1985; DUMAZERT \& LEVARD, 1987; DAMAIS, 1987).

O sistema família-estabelecimento apresenta uma dinâmica, se modifica no tempo. Há duas fontes de evolução do sistema família-estabelecimento: as transformações do sistema agrário e os eventos do próprio sistema.

O sistema agrário pode ser considerado como regido pelas leis econômicas dominantes no sistema econômico englobante, que são cristalizações 
históricas das relações sociais de produção e do desenvolvimwnto das forças produtivas (MAZOYER, 1985; DAMAIS, 1987), que portanto evoluem. Assim, os requisitos para que o sistema família-estabelecimento possa reproduzir-se ao longo do tempo no interior de um sistema agrário que evolui, igualmente se modificam. No atual estágio do desenvolvimento econômico e técnico, a acumulação de capital ao nível do estabelecimento se impõe para que o sistema consiga reproduzir-se no interior do sistema agrário existente. Isto pode implicar tanto em modificação dos fatores de produção como das combinações de produção, ou seja, transformar o sistema de produção, para que o conjunto sistema de produção-família continue a persistir.

A incidência dos elementos internos do sistema estabelecimento sobre a sua dinâmica está associada aos meios de produção disponíveis e a busca constante de coerência interna ou técnica. Os meios de produção presentes no estabelecimento podem variar quantitativamente e de forma autônoma, pelo menos no que se refere a superfície e mão de obra. Esta variação está relacionada com o aumento e diminuição dos efetivos de trabalho e a repartição da superfície quando da sucessão familiar (heranças).

Em síntese, estudar o funcionamento do sistema de produção consiste em : mostrar a lógica do encadeamento das decisões que o agricultor tomou para realizar o processo de produção a partir dos meios de produção disponíveis e desta maneira interpretar seu comportamento; fazer uma análise crítica deste funcionamento, isto é, verificar a eficiência das transformações e a reprodutibilidade do conjunto família e sistema de produção e, a partir desta propor modificações e prever o sentido da evolução do estabelecimento sob a ação das mudanças do contexto sócio-econômico, dirigidas, como as políticas agrícolas e as ações de desenvolvimento, ou não, como a inflação, a evolução comparativa dos custos, etc (SEBILLOTTE, 1979). 


\subsubsection{A decisão do agricultor: o modelo do comportamento adaptativo}

A análise das práticas, o que o agricultor faz, permite colocar em evidência certos condicionantes aos quais o agricultor está confrontado, no entanto, é insuficiente para entender o que o agricultor pretendeu fazer com sua ação, para esclarecer o conjunto de soluções que se oferecia a ele em um determinado momento e o que o levou a privilegiar certas soluções em detrimento de outras (SEBILLOTTE \& SOLER, 1990). Para identificar as transformações possíveis do sistema famíliaestabelecimento, de um ponto de vista de gestão, se impõe o estudo do processo de decisão do agricultor, ou seja, compreender as razões das escolhas técnicas e econômicas realizadas pelo agricultor e sua família.

Ao admitir que o agricultor tem razões para suas escolhas, se esta reconhecendo que ele dispõe de uma certa margem de liberdade, de um certo poder de decisão e que seu comportamento apresenta, pelo menos em parte, um caráter de intencionalidade ${ }^{8}$, suas ações tem um sentido e por isto é inteligível para um observador externo (BROSSIER et alii, 1990; SEBILLOTTE \& SOLER, 1990).

O comportamento observado, as práticas seja dos subsistemas ou do sistema família-estabelecimento é a expressão desta intenção do decisor, ou melhor é a expressão e o resultado de sua racionalidade. Para compreender a racionalidade das decisões de um indivíduo é necessário um quadro de leitura,

\footnotetext{
${ }^{8} \mathrm{O}$ axioma sob o qual repousa a microeconomia é de que o homem é racional em suas preferências e em seus atos : todo indivíduo toma as decisões que julga as melhores para si. Este enunciado não demonstrável, tem um valor heurístico, quer dizer, é útil na busca da compreensão dos fenômenos sócio-econômicos (BROSSIER et alii, 1990).
} 
ou de normas que permita apreendê-las e julgá-las. Estas normas são dadas pelos modelos decisionais usados : a maximização da renda ou de uma forma mais geral de uma função objetivo sob a reserva de considerar os condicionantes ligados a situação do agente que decide (BROSSIER et alii, 1990).

O problema da decisão, quer dizer, da escolha a ser feita, depende neste sentido, de duas série de variáveis : os objetivos do agente e as possibilidades deste realizá-los.

Os objetivos da maior parte das decisões humanas, individuais ou organizacionais, não buscam a otimização de uma função objetivo, mas simplesmente estabelecer ou restabelecer o equilíbrio do sistema com seu ambiente, conforme March e Simon", citados por BROSSIER et alii (1990). O agente irá parar de agir uma vez alcançado um primeiro equilíbrio, mesmo que não seja o melhor possível, pois a busca do ótimo poderá ser arriscado e é incerto.

À otimização de uma função objetivo é substituído pela invenção, muitas vezes por tentativas/erros, de uma solução satisfatória. $\mathrm{O}$ agente decisor não busca necessariamente a melhor decisão, mas uma decisão que aparece a ele satisfatória em um dado momento, tendo em vista as informações de que dispõe (BROSSIER, 1990; SEBILLOTTE \& SOLER, 1990).

Em uma organização não é apenas um indivíduo que toma as decisões, mas há uma estrutura complexa. As decisões dependem da relação de força entre os diferentes membros da família, e portanto as decisões são o resultado de um processo de confrontação e de negociação (BROSSIER et alii, 1990).

\footnotetext{
${ }^{9}$ MARCH, J. C. \& SIMON, H. Organisation, problèmes psycho-sociologiques. Paris, Dunod, 1964. 240p.
} 
De outra parte, há uma multiplicidade de níveis de decisão e as finalidades se estruturam hierarquicamente. Cada nível de decisão deve ser considerado como um fim em relação ao nível inferior e como um meio para alcançar o nível superior SEBILLOTTE \& SOLER (1990). Os objetivos são difererenciados em objetivos principais ou fundamentais e objetivos secundários ou parciais. Os objetivos principais conformam um quadro no interior do qual são tomadas as decisões.

A partir destas considerações BROSSIER (1973) formula um conjunto de pressupostos, a partir dos quais formula o modelo do comportamento adaptativo para representar o processo decisório no sistema família-estabelecimento ::

a) não é um único indivíduo isolado que toma as decisões;

b) o critério de decisão não é a maximização de um objetivo ou utilidade mas a obtenção de uma solução satisfatória ou aceitável;

c) não há um objetivo único, mas objetivos hierarquicamente estruturados e eventualmente algo conflitantes;

d) o estabelecimento tem relações com o contexto sócio-econômico e ecológico, o que poderá significar potencialidades ou impor restrições suplementares, e estas relações não são estáticas;

e) as organizações tem suas próprias normas, seja de controle, de escolhas, etc, que se modificam;

f) não existem modelos universais aplicáveis a todas as situações e apropriadas a cada uma;

g) a análise do decisor de sua própria situação pode melhorar sua capacidade de formular e realizar seu projeto de ação. 
Estes pressupostos articulam-se em torno do postulado de racionalidade limitada, que pode ser enunciado da seguinte maneira : todas as decisões do agricultor relativas ao seu empreendimento tem um sentido implícito ou explícito, mais precisamente, elas buscam atingir um ou mais objetivos, no contexto das ações percebidas como possíveis em um dado momento, considerando a visão que este tem de sua situação e as finalidades fixadas para o estabelecimento (BROSSIER, 1973; BONNEVIALE et alii, 1989).

O significado deste postulado é que as decisões e ações são ótimas no momento que o agricultor as tomou e implementou, tendo em vista os objetivos que buscava alcançar e a percepção que tinha da situação. Deste modo, a coerência e racionalidade são contingentes e situacionais e não se referem nem à racionalidade do sistema econômico e tampouco ao julgamento que um observador exterior ou o próprio agricultor porventura venha a fazer posteriormente (BROSSIER, 1973)

Os pressupostos e o postulado de racionalidade acima expostos, conformam uma representação mais próxima da realidade do processo decisional do agricultor - o modelo do comportamento adaptativo. Reconhece-se uma capacidade de adaptação permanente do agricultor. Com efeito, o postulado da racionalidade implica que toda ação visa modificar a situação do decisor adaptando-a, na medida de suas possibilidades, a um objetivo e. inversamente, face a um problema, o decisor é levado a se interrogar sobre seus objetivos.

Dito de outra maneira, o agricultor para realizar seu projeto, adapta permanentemente seu comportamento em função de sua situação e da percepção que tem dela. Há portanto, um duplo processo de adaptação, do projeto a situação e da situação ao projeto. 
O funcionamento deste modelo de decisão conduz às seguintes características (BONNEVIALE, 1990) :

- a decisão de agir resulta da análise mais ou menos consciente que faz o agricultor de sua situação e de seus objetivos;

- as decisões são hierarquizadas, desde decisões de orientação geral do estabelecimento até as decisões diárias. Esta hierarquia tem sua correspondência igualmente na estrutura dos objetivos.

O modelo de comportamento adaptativo assenta-se nos conceitos chaves: de : situação, projeto e percepção.

A situação é constituída pelo conjunto de elementos que, a um dado momento, intervêm sobre as possibilidades de ação do agricultor. Estes elementos podem favorecer as possibilidades de ação do agricultor e neste caso são denominados de potencialidades, podem limitar sua ação sendo então denominados de restrições e elementos que no momento não exercem influência positiva ou negativa, são os elementos neutros (BONNEVIALE et alii, 1990).

É importante salientar que as potencialidades ou as restrições só tem sentido em relação aos objetivos do agricultor, não se pode qualificar um elemento de potencisl ou de restrição em absoluto.

Percebida no presente a situação resulta tanto da evolução passada como do contexto não controlado com os meios que o agricultor dispõe (incertezas econômicas e climáticas, por exemplo). As potencialidades e as restrições resultam tanto do contexto quanto da história passada do estabelecimento e da família. 
Em uma empreendimento se pode reconhecer os objetivos que são determinados pelo grupo familiar e os objetivos que são estabelecidos pelos agentes que conduzem diretamente o sistema de operações (BROSSIER et alii, 1990; BONNEVIALE et alii, 1990).

O grupo familiar ou o(s) proprietários, no caso de uma empresa, determina para um período de tempo dado, o sentido da atividade daqueles que irão conduzir o sistema de operação, ou seja um conjunto de objetivos mais ou menos explícitos e mais ou menos hierarquizados. Este conjunto de objetivos é chamado de

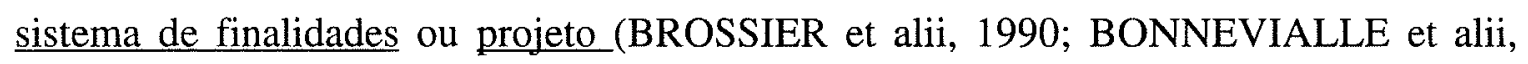
1990).

A realização do projeto implica um conjunto de objetivos a este subordinado, que são definidos pelos agentes que conduzem diretamente o sistema de operações, possibilitando a estes tomar as decisões que permitem dirigir o dia a dia, mas também de fazer evoluir o sistema ao longo do tempo.

CAPILLON et alii (1975) classificam os objetivos em três níveis :

- nível global, refere-se às orientações gerais dadas pelo agricultor e sua família ao estabelecimento, correspondendo a objetivos como o de lucro, no caso de uma empresa agrícola, como o de instalação de um sucessor ou o de manutenção de um determinado nível de renda mínimo, no caso da unidade familiar de produção

- nível estratégico, diz respeito às orientações a médio prazo do sistema de produção, incluindo as produções e atividades do estabelecimento, os principais meios de produção, seu financiamento; 
- nível tático, corresponde aos objetivos de curto prazo, que presidem a realização das técnicas de produção - sistemas de cultivo, sistemas de criação, práticas ligadas a comercialização de produtos, etc;

Ao nível global ou de projeto são definidos as grandes características do sistema de produção levando em conta, evidentemente, os parâmetros do meio ambiente existentes (mercados, meio físico, etc). Decide-se portanto os principais processos produtivos e o seu grau de intensificação, trata-se de decisões estratégicas (BOURGEOIS, 1983b).

As decisões estratégicas fixam um quadro (objetivos estratégicos a alcançar) no qual se inserem as decisões táticas (tipo de sucessão, o nível de adubação, tipo de manejo dos animais, etc), e estas determinam um quadro para as decisões técnicas ou operacionais (escolha do preparo do solo em determinado momento, do herbicida, quantidade de forragem dada aos animais, etc)

DARRÉ (1989), observa que as escolhas dos agricultores não são determinadas por situações objetivas mas pelo conhecimento que ele tem dela, ou seja da percepção que tem da situação.

A percepção é a maneira como o indivíduo representa para si uma situação ou seus projetos. As decisões do agricultor resultam da confrontação das percepções do projeto e da situação. As percepções são essencialmente aproximativas e individuais e evoluem ao longo do tempo. Ao passar a ação o decisor pode se deparar com dificuldades que colocam em cheque sus percepção tanto da situação como de seus objetivos. O que sugere que os conhecimentos, no sentido geral do termo, progridem quando o indivíduo se depara com dificuldades. 


\subsubsection{Tipologia do funcionamento : instrumento para o estudo regional dos} estabelecimentos agrícolas

A constatação de que em uma região, independentemente da heterogeneidade do meio físico e da distribuição desigual dos meios de produção entre os agricultores, há uma diversidade de maneiras de produzir (CAPILLON, 1985), levou os pesquisadores à elaboração de métodos que permitissem apreender esta diversidade. Estes métodos devem ser capazes de detectar a gama de sistemas de produção existentes, sem no entanto cair em um particularismo paralisante (PERROT \& LANDAIS, 1993) a que um procedimento monográfico exclusivo poderia levar.

Para representar a diversidade existente procede-se a divisão da população de estabelecimentos agrícolas em subgrupos. Não se trata de uma simples classificação, isto é, de uma divisão morfológica segundo alguns critérios simples dos recenseamentos (superficie do imóvel, superficie agrícola útil ou idade do agricultor), mas de uma tipologia, quer dizer, de uma divisão funcional apoiada em uma teoria apropriada que orienta a interpretação dos dados obtidos por enquetes e que permite reagrupar os estabelecimentos que apresentam modos de funcionamento semelhantes (CAPILLON, 1985; DEFFONTAINES \& PETIT, 1985; BENOIT et alii, 1987).

A tipologia pode ser definida como um modelo de representação dos estabelecimentos componentes de uma agricultura local ou regional, que se baseia em uma distinção de tipos de estabelecimentos agrícolas elaborada a partir de critérios, seja estruturais, funcionais ou de performances (BONNEVAL, 1993).

Os objetivos de uma tipologia, de uma maneira geral, são (JOLLIVET, 1965) : fornecer um quadro de referência que permita extrair os elementos significativos 
a comparar, dando um sentido compreensivo ao conjunto; tornar comparável os objetos estudados, pois estes são analisados segundo os mesmos atributos; permitir que os objetos possam ser situados uns em relação a outros, respeitando suas especifidades. A maior parte dos métodos utilizados para tipificar os estabelecimentos agrícolas se inspiram nestes objetivos teóricos.

Em função do modo de observação empírica e da lógica da construção dos tipos é possível distinguir tipos empíricos ou extraídos e tipos construídos (PERROT \& LANDAIS, 1993).

Os tipos extraídos são deduzidos dos dados concretos de observação e baseados nas tendências médias e em caracteres comuns que aparecem ao associar diversos atributos escolhidos para descrever os objetos observados. Os atributos de distinção dos tipos são obtidos empiricamente, a partir das características mais evidentes, mais acessíveis ao observador, ou seja, àqueles cuja variabilidade é mais evidente (PERROT \& LANDAIS,1993).

A preocupação em construir tipos explicativos, não apenas descritivos, levou que se desse maior atenção a escolha dos atributos a observar e mesmo a escolha a priori das dimensões do espaço dos atributos. São estas escolhas que condicionam a expressão dos fenômenos a estudar. Assim, as relações entre os elementos associados a construção tipológica são determinados pelo ponto de vista inicial.

Os tipos construídos, resultam desta compreensão da observação e da análise da variação. Deste modo, os tipos construídos não procedem das tendências médias e de caracteres comuns, mas são deduzidos de uma posição teórica e elaborados/precisados a partir da observação dos objetos, buscando enfatizar os 
caracteres discriminantes, daí a variabilidade de critérios não específicos. PERROT \& LANDAIS (1993) concluem que é à concepção do tipo construído que esta associada a abordagem sistêmica do funcionamento dos estabelecimentos agrícola.

PERROT \& LANDAIS (1993) consideram que uma tipologia dos estabelecimentos agrícolas construída a partir de seus funcionamentos pode suprir as seguintes funções : fornecer aos planejadores um quadro regional, útil para orientar as ações de desenvolvimento e para proceder análises de grupo; permitir organizar a orientação individual dos produtores; orientar a pesquisa de referências técnicas; definir o domínio de validade das inovações técnico-científicas propostas.

As relações entre diversidade de estabelecimentos e seu funcionamento, sua lógica interna, podem ser abordadas de diversos ângulos e a diferentes níveis. Duas orientações são dominantes (BONNEMAIRE, 1988) : abordagens da diversidade centradas na noção de sistema de produção e abordagens centradas sobretudo na diversidade de práticas dos agricultores.

Quando é analisada a diversidade dos sistemas de produção, geralmente a ênfase é colocada na economia do estabelecimento e no sistema agrário envolvente. Concentra-se a análise nos processos se decisão, na utilização do espaço rural, no peso dos condicionantes econômicos externos e na adaptação do sistema através das escolhas técnicas (BONNEMAIRE, 1988).

A abordagem da diversidade pelas práticas se ocupa da diversidade no interior dos estabelecimentos. Em geral, apresenta uma entrada pela dimensão social das práticas, privilegiando a ação dos agentes sociais, e outra entrada pela dimensão propriamente técnica, enfatizando os processos de elaboração da produção (BONNEMAIRE. 1988). 
JOUVE (1992) também distingue duas maneiras de fazer tipologias, segundo se privilegia o funcionamento sócio econômico ou o funcionamento técnico do estabelecimento. No primeiro caso, estabelecem-se tipologias estruturais, ou seja, baseadas na natureza e as modalidades de organização e combinação dos meios de produção. No segundo caso, a tipologia terá um caráter funcional sendo baseada na análise dos processos técnicos de produção. Entretanto, a análise diacrônica das escolhas estratégicas operadas pelos agricultores, aparece para este autor, como um meio privilegiado para estabelecer tipologias que tenham valor tanto compreensivo como preditivo.

As tipologias de estabelecimentos agrícolas orientadas para a ação e que se reclamam sistêmicas, são construídas, em sua grande maioria , a partir de enquetes diretas utilizando questionários mais ou menos fechados, aplicados a uma amostra reduzida da população de estabelecimentos. Com base nestas enquetes, estas unidades produtivas são repartidas em um certo número de tipos de funcionamento que em seguida são descritos a partir de suas características. A diferença entre os diferentes métodos está, essencialmente, na natureza das dados a recolher e na maneira como estes são tratados.

CAPILLON \& MANICHON (1979) propõem que cada tipo seja definido por suas estratégias de produção, que se expressam fundamentalmente nas combinações de atividades de produção. Os tipos de funcionamento são ainda restituídos a algumas trajetórias de evolução. A trajetória é definida pelas etapas do desenvolvimento dos estabelecimentos da região, correspondendo aos tipos de funcionamento em determinado momento e os mecanismos que permitiram a passagem de um tipo a outro. 
Tanto os tipos de funcionamento existentes e passados e os mecanismos de passagem são obtidos através da enquete (CAPILLON \& SEBILLOTTE ,1980; CAPILLON, 1985).

Certas tipologias são baseadas sobre o projeto e a situação dos agricultores (DEFFONTAINES \& PETIT, 1985; BENOIT ET alii. 1987). Estes autores consideram que é o projeto a longo prazo que dá coerência ao conjunto de decisões concernentes ao sistema de produção e as escolhas técnicas de produção, o que permitiria que os tipos construídos tenham certa estabilidade.

A dificuldade de identificar corretamente o projeto mantido pelo agricultor levou que certos pesquisadores (CRISTOFINI, 1985; ROYBIN, 1987) privilegiassem o estudo das práticas na enquete e, no tratamento das informações, a descrição dos sistemas de práticas. O sistema de práticas é definido como as relações lógicas e funcionais que ligam entre elas as diversas práticas operacionalizadas pelo agricultor. São os sistema de práticas que permitem reagrupar os diversos tipos de funcionamento observados em um certo número de tipos limitados.

CAPILLON et alii (1975 e CAPILLON e MANICHON (1991) utilizam o estudo das práticas para revelar a coerência das escolhas do agricultor e testar a formulação das escolhas estratégicas. Entretanto, as relações entre prática e funcionamento do estabelecimento não tem o mesmo status na confecção das tipologias, como no método proposto por CRISTOFINI (1985) e por LANDAIS \& DEFFONTAINES (1989).

O procedimento proposto por CAPILLON et alii (1975) é o inverso. Elaboram-se os tipos de funcionamento, privilegiando o nível estratégico, e depois são analisadas as práticas, sua variabilidade no interior de cada tipo. 
A construção de cada tipo, o modelo de funcionamento, é deduzida a partir da comparação do funcionamento das unidades individuais, seja pelo esquema de funcionamento (CAPILLON \& MANICHON, 1979), ou por sua situação/projeto (DEFFONTAINES \& PETIT, 1985), ou ainda a partir de sistemas de práticas (CRISTOFINI, 1985).

Segundo o ponto de vista que se adota cada tipo é legítimo (JOUVE, 1992). Pode-se estabelecer tipos em função de problemas específicos (acesso a terra, possibilidade de introduzir uma cultura, nível de intensificação, etc) ou de caráter mais geral. O importante é que se busque o máximo de coerência lógica para cada tipo em um objetivo de compreensão.

Após a identificação dos tipos de funcionamento são determinados os respectivos efetivos na região. Com base nos atributos e definições que serviram para criar a tipologia é elaborada uma chave de determinação, que permite classificar todo estabelecimento da região em um tipo 


\section{DISCUSSÃO}

\subsection{Pesquisa-Desenvolvimento e abordagem sistêmica : interesse e limitações}

O foco deste trabalho está centrado na análise e julgamento preliminar da situação, o diagnóstico, em uma operação de Pesquisa-Desenvolvimento.

O diagnóstico de uma situação implica que o pesquisador não mais escolhe as condições de sua pesquisa, pois não se trata de responder a uma questão formulada por este, mas do exterior, da demanda social (LEGAY, 1988). Em consequiência, decide-se aceitar mais complexidade do que a decorrente de algumas hipóteses, o que tem um efeito sobre as metodologias e sobre a organização prática da pesquisa.

A identificação da(s) questão(ões) que levaram a uma demanda de intervenção, isto é, do problema de pesquisa, é um procedimento em que participam os organismos de desenvolvimento. os agricultores atingidos e os pesquisadores.

Os responsáveis por organismos de desenvolvimento econômico geralmente formulam os problemas em termos bem gerais, de elevação da produção de tal cultura, conservação da fertilidade do solo, diminuição das perdas de colheita, ou seja, problemas que concernem muito mais a agricultura como um todo que o agricultor. 
O agricultor administra um sistema, seu estabelecimento, que é finalizado por diversos objetivos definidos por ele e sua família confrontados a uma situação concreta. Para ele os problemas que interessam são aqueles que impedem um funcionamento ótimo de seu sistema. As soluções que demanda devem ser compatíveis como seu sistema atual. Em conseqüência, não demandará forçosamente as técnicas que permitem os rendimentos mais elevados para tal cultura ou criação, mas aquelas que respeitam a prioridade de objetivos e sua organização de trabalho.

A participação dos agricultores neste procedimento não está portanto relacionado apenas a uma intenção de diminuir as distâncias de diálogo entre técnicos e agricultores, o próprio método de investigação necessita desta participação para garantir um justo conhecimento das escolhas técnicas e portanto das estratégias e dos projetos dos agricultores. A participação assegura uma formação eficaz dos produtores e permite uma circulação efetiva das informações. De outra parte, esta participação pode prevenir um desvio freqüente neste tipo de pesquisa que é o de acumular dados buscando maior rigor científico e deixando de lado as preocupações com a ação (PILLOT, 1984).

Os extensionistas além de aportar elementos para a análise, serão os responsáveis pelo acompanhamento e monitoramento da apropriação das técnicas preconizadas e poderão aprimorar constantemente o diagnóstico, por esta razão a sua participação se coloca como necessária.

Aceitar que o agricultor tenha lugar central na identificação do problema, significa que em uma Pesquisa-Desenvolvimento o que interessa primeiramente é o problema global da gestão técnica e econômica do estabelecimento agrícola tal qual se coloca para o agricultor. 
Para os pesquisadores e para os extensionistas isto significa que não se trata apenas de caracterizar as conseqüências das técnicas sobre o meio biofísico e a produção agrícola, mas examinar também a operacionalização destas técnicas e elucidar suas escolhas, o que é indispensável para propor melhorias ou inovações utilizáveis (GRAS et alii, 1989). Em função disto, duas categorias de questões científicas podem ser distinguidas :a primeira está associada a elaboração do rendimento de uma população vegetal ou de performances de uma população animal, sobre a qual aplicamse um conjunto lógico e ordenado de técnicas culturais; a segunda categoria de questões diz respeito às condições de operacionalização das intervenções técnicas.

As condições de operacionalização das técnicas é como se coloca o objetivo do diagnóstico de uma situação para os agentes que participam em uma operação de Pesquisa-Desenvolvimento. Este é o objeto do presente trabalho.

A operacionalização introduz uma finalidade do conhecimento, a ação e a gestão, que se situa ao nível da família e do sistema de produção. A finalidade do conhecimento é responder a questão geral, que pode ser formulada da seguinte forma : como e por que o agricultor faz determinadas escolhas seja de curto, médio ou longo prazo?

Para responder esta questão, é necessário considerar fenômenos que intervêm a diversos níveis de organização do processo de produção agrícola - a parcela cultivada, o estabelecimento agrícola, e mesmo a região. Cada um destes níveis de organização é constituído de diversos componentes em interação e estão interrelacionados de forma hierárquica. Para apreender esta organização a abordagem em termos de sistemas é notadamente útil. 
Os sistemas são representações/modelos do real, não a realidade. A representação de uma realidade multifacetada e complexa, polissistêmica, impõe uma simplificação. Trata-se de precisar os limites do(s) sistema(s) a estudar, isto é, de separar da realidade um conjunto possuindo as qualidades de totalidade, de independência e autonomia, de organização interna suficiente para justificar um estudo separado e do ponto de vista da representação/conhecimento buscado.

O fato técnico que é estudado pelos engenheiros agrônomos é geralmente referido a uma porção do espaço e a uma escala de tempo determinada. O sentido de escala de espaço no entanto, não é necessariamente de natureza física, é sobretudo conceptual. O tempo engendra duas categorias de estudos : diacrônicos e sincrônicos.

A escala espacial de estudo privilegiada é determinada pelo objetivo de estudo (LEGAY. 1988). Por exemplo, a planta, a parcela cultivada, o estabelecimento agrícola, a região, são objetos físicos mas sua representação decorre de uma concepção de seu funcionamento.Uma vez identificado o objetivo de estudo, deve-se escolher um ou vários destes níveis, o que leva a se reportar a escala de espaço e uma concepção prévia.

Os processos estudados não se constituem da mesma forma para todos e se modifica ao longo do tempo, são diferenciados e dinâmicos. Por esta razão ao engenheiro agrônomo interessa o estudo de um sistema a um dado momento e a comparação de vários destes entre si, estudos sincrônicos, e a evolução possível e/ou desejável, estudos diacrõnicos. 
A abordagem sistêmica do real é assim um procedimento metodológico e uma postura frente ao real, que procura abranger ao mesmo tempo as partes constituintes do objeto complexo, o sistema estudado, e as interrelações que se estabelecem dentro dele e com exterior, reconciliando as abordagens sincrônicas, abordagem da estrutura e funcionamento, com as abordagens diacrônica, evolução histórica.

Os conceitos sistêmicos utilizados para representar os diferentes níveis de organização da produção são conceitos de funcionamento, correspondendo a cada um instrumentos e métodos específicos de diagnóstico.

Como toda abordagem da realidade, a abordagem sistêmica opera uma redução de sua complexidade para poder representá-la. Esta redução/representação é conformada nos modelos. Um primeiro risco é tomar os modelos como uma realidade e não como uma ferramenta para pensar a realidade. Um segundo risco é do reducionismo as avessas, quer dizer, explicar o todo sem estudar suas partes constituintes, ou pior, deduzir as partes da observação do todo.

A abordagem sistêmica é uma ferramenta útil e necessária em uma ação de desenvolvimento, porém não aporta nada de construção conceptual radicalmente nova que conduza uma melhor compreensão dos fenômenos observados (KROLL, 1985). Na verdade, como diz Ivan Barel, citado por MORIN (1987), a idéia de sistema é uma problemática, no sentido mais forte ou exato do termo, isto é, uma maneira de descobrir problemas que não podiam ser percebidos de outro modo. Não tem, em si mesmo força para encontrar uma solução para os problemas identificados, porém auxilia a sua preparação. 
A conversão das demandas/objetivos em objeto científico. coloca uma segunda questão, além da escala de estudo, a organização disciplinar.

Muitos dos objetivos formulados a partir das demandas sociais podem ser divididos de tal forma que tornam-se objetos teóricos de uma disciplina. O fato de se tratar de um diagnóstico finalizado de situações concretas, ou seja, de sistemas complexos, resultantes de combinação de fenômenos físico-biológicos e sócioeconômicos, interdita uma abordagem por apenas uma disciplina. Certos sistemas são mais biológicos como por exemplo a parcela cultivada, outros mais sócio-econômicos como a região e outros como o estabelecimento agrícola são interfaces deste tipo de pólos de aglutinação de conhecimentos. No entanto, todos os níveis de organização do processo de produção agrícola podem ser abordados tanto do ponto de vista biológico como sócio-econômico.

Numerosos autores insistem sobre o caráter necessariamente pluridisciplinar do diagnóstico, o que é evidente na abordagem sistêmica. A simples reunião de engenheiros agrônomos, de economistas, de veterinários, sociólogos em uma equipe não basta para realizar um trabalho pluridisciplinar. Muitas vezes, as contribuições de cada um se dão apenas a partir de seu ponto de vista disciplinar, abordagens setoriais, sem que se possa conhecer globalmente o objeto estudado. PILLOT (1984) observa que é preferível que o projeto seja conduzido por engenheiros agrônomos generalistas ou sócio-economistas, segundo o caso, interessados no conjunto das atividades produtivas da região e apoiados em um grupo de especialistas. O que importa é que seja a demanda do terreno ou as hipóteses reveladas pelo diagnóstico deve demandar a solicitação de apoio dos especialista e não o contrário. 
A relação da pesquisa sistêmica e a pesquisa temática, pode ser colocada nesta mesma direção.

A pesquisa sistêmica se interessa pelos conjuntos e pelas relações dinâmicas dos constituintes dos sistemas estudados. A pesquisa temática agrícola tem por finalidade aprofundar o estudo do comportamento dos componentes biofísicos ou sócio-econômicos do sistema segundo uma lógica setorial. No entanto, estes dois tipos de pesquisa não são opostos, sendo mesmo complementares.

A pesquisa em sistemas pode valorizar as técnicas produzidas pela pesquisa temática integrando-as na construção de novos sistemas melhor adaptados as exigências do desenvolvimento : seja suscitando pesquisas analíticas necessárias para a elaboração de novos sistemas, quando inexistem referências para tal, e de uma maneira mais geral ao identificar e hierarquizar os condicionantes técnicos e econômicos que limitam a produção ela contribui para orientar os programas de pesquisa temática.

Inversamente, as possibilidades de análise e de julgamento dos sistemas de exploração agrícola do meio e das práticas dos agricultores são largamente dependentes dos métodos de estudo e dos conhecimentos dos mecanismos elaborados pelas disciplinas concernentes as práticas julgadas.

A constituição de um referencial técnico pode ser elaborado por duas vias : a enquete e a experimentação.

Da mesma forma que a pesquisa temática e a Pesquisa-Desenvolvimento não se opõem, a experimentação, procedimento em geral único da primeira não se opõe a enquete, procedimento predominante no segundo tipo de pesquisa. GRAS et alii 
(1990) consideram que a enquete, incluindo-se aí o acompanhamento, e a experimentação são complementares pois não tem as mesmas vantagens e os mesmos inconvenientes. Estes dois procedimentos de estudo devem ser considerados como modalidades de um método único no qual recorre-se a um ou outro procedimento dependendo do problema colocado e dos resultados intermediários obtidos ao longo da operação de pesquisa.

\subsection{O diagnóstico do estabelecimento: agrícola: : aportes, dificuldades e limites}

.O reconhecimento de que o estabelecimento agrícola não é uma simples justaposição de atividades produtivas e fatores de produção, mas um sistema organizado pelas interações de seus múltiplos componentes e subsistemas, dá outra perspectiva para a intervenção técnica.

Ao intervir sobre um componente deste sistema se estará afetando a organização do conjunto e os resultados buscados poderão não ser alcançados, por esta razão se impõe a análise e o julgamento da situação, o diagnóstico do funcionamento atual do sistema.

O diagnóstico do estabelecimento agrícola consiste na identificação e avaliação de seus pontos fortes e fracos, bem como na busca de suas causas. É um diagnóstico segundo um procedimento compreensivo e não normativo, isto é, considera o agricultor e sua família, seus objetivos e os condicionantes de sua situação. Preocupase em evidenciar o funcionamento do sistema família-estabelecimento. 
O diagnóstico do estabelecimento agrícola é uma ferramenta útil :

- na fase preparatória de um projeto de desenvolvimento visando a transformação e a melhoria dos sistemas de produção;

- nas ações de aconselhamento gerencial do agricultor;

- no quadro dos programas de extensão e assistência técnica a fim de adaptar o conteúdo das proposições a diversidade de estabelecimentos

A abordagem global, combinação do procedimento sistêmico e da teoria do comportamento adaptativo, ao propor um método de acesso a compreensão do funcionamento do estabelecimento, fornece um mecanismo essencial para a construção do diagnóstico.

Um primeira questão está associada a representação sistêmica do estabelecimento. A abordagem sistêmica não é uma teoria do estabelecimento agrícola, fornece, isto sim, um modo de decomposição deste em subsistemas, porém não diz nada sobre quais são os subsistemas pertinentes e, sobretudo não fornece nenhuma chave para esta decomposição (BONNEVIALE et alii, 1989). O estudo dos subsistemas colocam ainda dois problemas adicionais :

- o da definição do subsistema, isto é, como caracterizá-lo, quais são os seus elementos, fluxos, fronteira, como se interrelacionam com o conjunto famíliasistema de produção;

- o da compreensão de seu funcionamento, que coloca a questão da observação/descrição das práticas. 
DEFFONTAINES \& PETIT (1985), notam que toda arte do modelizador consiste em combinar harmoniosamente a abordagem global e a abordagem setorial, pois não há um método codificado para articular estas duas abordagens. Esta combinação é essencialmente empírica, por isto a existência de diversos métodos de diagnósticos.

Estudar as práticas de um agricultor, não é somente observar a maneira de executar alguma operação técnica, mas é isto sim procurar compreender como ele organiza esta operação e porque utiliza esta ou aquela maneira de fazer.

A observação das práticas tornou-se um procedimento essencial por que contribui para explicar o funcionamento do estabelecimento agrícola. Com efeito, as práticas são reveladoras : dos objetivos do agricultor, da tecnicidade do agricultor e do referencial técnico utilizado pelo agricultor;

Ao afirmar que as práticas são reveladoras dos objetivos do agricultor implica dizer que o procedimento de análise se apoia sobre o resultado da ação e não sobre um a priori, quer dizer, que este ou aquele comportamento decorre deste ou daquele objetivo.

A descrição destas práticas, o que LANDAIS \& DEFFONTAINES (1990) denominaram de estudo da modalidade das práticas, sua análise e julgamento, sua eficácia e oportunidade, segundo estes mesmos autores, comportam divergências metodológicas.

Duas proposições metodológicas, a formalizada pela equipe da Chaire d’Agronomie do Institut National Agronomique de Paris e a formalizada conjuntamente 
pelas unidades de pesquisa SAD (Systèmes Agraires et Développement) de Dijon e Versailles, são particularmente interessantes para confrontar metodologias. São proposições que podem ser executadas por equipes pequenas e mesmo constituídas por uma equipe de apenas engenheiros agrônomos.

Para a equipe do INA-PG (CAPILLON et alii, 1975; CAPILLON \& MANICHON, 1991) a abordagem global do estabelecimento agrícola se fundamenta em quatro postulados :

1) o estabelecimento agrícola é um sistema;

2) são as decisões dos agentes do sistema que o fazem evoluir. O processo de tomada de decisão tem um papel central na dinâmica do sistema. Três níveis de objetivos de decisão são distinguidos - global, estratégico e tático. Em relação a estes objetivos são identificados os componentes internos do estabelecimento e do seu ambiente favoráveis ou limitantes.

3) a relação família-estabelecimento tem uma influência determinante sobre o funcionamento do sistema de produção, pois a família é fonte de mão de obra, influencia as decisões, tem papel preponderante na sucessão do agricultor e sua história intervêm na constituição do patrimônio;

4) a simulação das possibilidades de evolução futura do estabelecimento colocam o interesse de sua história, de tal forma que esta revele certas relações permanentes entre a família e o estabelecimento, seja de ordem econômica, ou psicossociológica, permitindo compreender como a atual situação foi atingida. 
As informações a buscar são organizadas e sintetizadas em um guia de entrevista, que contem seis domínios de estudo : levantamento dos dados principais do sistema de produção, as relações específicas de cada um dos subsistemas, os problemas de sucessão, a história da família, as etapas de evolução do estabelecimento e as possibilidades de evolução futura.

A partir das informações obtidas e de sucessivas síntese parciais são construído dois esquemas : um diagrama gráfico concernente ao funcionamento atual, salientando a natureza dos objetivos e dos condicionantes internos e externos; outro sob forma de tabela ou gráfico que traduz a evolução do sistema de produção, suas principais etapas e as condições de passagem de uma etapa a outra.

O exame crítico de diferentes procedimentos que se denominam de global, levaram BENOIT et alii (1988) a apontar os seguintes problemas que um método deveria superar :

- o perigo de ser superficial, satisfazendo-se em analisar as grandes decisões, ditas estratégicas, sem se preocupar com as decisões do dia a dia;

- o risco de privilegiar as dimensões familiar, sociológica e histórica em prejuízo das dimensões técnicas e das práticas dos agricultores, base da análise dos engenheiros agrônomos;

- o inconveniente de uma aceitação complacente das boas razões do agricultor, impedindo um julgamento crítico.

A partir destas considerações as equipe do SAD de Versailles e Dijon, propõem um método de diagnóstico global do estabelecimento agrícola (DIGREX), com as seguintes características : 
1) buscar a elaboração, em um tempo curto, de um diagnóstico, fazendo um balanço dos pontos positivos e fracos do estabelecimento a um dado momento, assegurando-se em cobrir o essencial dos aspectos produtivos;

2) o diagnóstico é conduzido por um observador externo, que utilizando um referencial local irá avaliar as performances das diferentes atividades do estabelecimento e as ligações que estas tem entre si;

3) para apreender o conjunto complexo que constitui o estabelecimento agrícola, são distinguidas de uma parte as atividades produtivas e os processos para as realizar, de outra parte os fatores de produção, colocando-se sempre se os fatores de produção são potencialidades ou restrições a elaboração das produções, dando ainda relevância aos fluxos monetários e os resultados econômicos;

4) é através de uma enquete, com a participação de pelo menos um dos responsáveis do estabelecimento, que se realiza o levantamento das informações.

A proposição metodológica da equipe do INA-PG e esta última logo acima referida, distingue-se tanto por conduzir de forma distinta a apreensão da globalidade como pela modo como são julgadas as práticas dos agricultores.

O método apresentado por BENOIT ET alii (1988) corre o risco ao cindir o estabelecimento em atividades produtivas, de fazer avaliações de valor setorial, não considerando suficientemente o quadro geral, do sistema de produção, no qual a atividade encontra a sua coerência. Ao propor como critérios predeterminados de julgamento dos pontos fracos e fortes as possibilidades de aumentar a produção ou de diminuir o consumo de insumos, o método não considera os objetivos do agricultor e assim é inapropriado para o aconselhamento técnico e gerencial do agricultor. Contribui, 
por outro lado, para identificar o campo das possibilidades das evoluções possíveis dos sistemas existentes.

O método desenvolvido pela equipe do INA-PG propõe que em um primeiro momento se deve evidenciar a lógica do funcionamento global do estabelecimento, isto é, apreender as razões que levaram o agricultor a tomar suas decisões, sobretudo estratégicas, abstendo-se de julgar estas decisões e os objetivos revelados por estas decisões,. O julgamento do técnico, em um segundo momento, está associado a reprodutibilidade do sistema, quer dizer do conjunto, é por isto que qualquer prática específica deve ser julgada de forma global (CAPILLON, 1988). Ao traçar a trajetória de evolução de cada estabelecimento, este método possibilita ainda interpretar as reações dos agricultores de uma região as diferentes iniciativas de fomento já realizadas. Por estas razões este método é mais apropriado para o aconselhamento técnico e gerencial. Do ponto de vista da formação do engenheiro agrônomo, ao exigir uma compreensão do conjunto das práticas do agricultor, sem privilegiar uma dimensão específica, auxilia na formação de uma imagem simplificada, porém não simplificadora, pois fragmentada, da realidade.

\subsection{Interesse e limitações dos métodos tipológicos}

Os métodos tipológicos para representar a diversidade de estabelecimentos agrícolas de uma região, baseados no funcionamento destes estabelecimentos, utilizam como atributos classificatórios características da estrutura e projeto (CAPILLON et alii, 1979; DEFFONTAINES \& PETIT, 1985) ou do sistema de 
práticas (CRISTOFINI, 1985; LANDAIS \& DEFFONTAINES, 1989). Estes atributos conformam o campo possível das práticas e caracterizam as ações dos agricultores.

Nestes métodos não há nenhum préjulgamento da tecnicidade dos agricultores, ou de sua maior ou menor capacidade de inovar. As tipologias construídas são de natureza compreensiva, preocupando-se em diferenciar as maneiras de produzir existentes na região utilizando atributos e suas variações observados e/ou deduzidos localmente. Contrapõem-se, fundamentalmente, as classificações normativas, sejam estas baseadas em índices técnicos ou na reação dos agricultores as propostas de inovações formuladas pelos técnicos. Esta é uma característica comum dos métodos tipológicos acima citados.

As tipologias de funcionamento permitem agrupar os estabelecimentos em tipos efetivamente comparáveis entre eles e no interior de cada tipo. Esta comparação entre tipos e no interior do tipo possibilita o julgamento do funcionamento do estabelecimento, detectar as soluções possíveis aos problemas identificados, elaborar as recomendações técnicas adaptadas e organizar um dispositivo de extrapolação destas recomendações.

Ao dividir a variabilidade total que existe em uma população estudada, no caso os estabelecimentos agrícolas, em dois componentes, inter tipos e intra tipo, os métodos tipológicos confrontam-se as suas limitações.

O ideal de toda tipologia consiste é obter tipos com o máximo de homogeneidade e individualização, minimizando a variância intra tipo. No entanto, isto não pode ser obtido ao custo da multiplicação dos tipos. Na prática o número mínimo não pode ser muito pequeno, pois as diferenciações entre os tipos seria tão evidente que 
pouca contribuiria para melhorar o conhecimento da região. Não pode, por outro lado, ser muito grande pois a tipologia seria de difícil utilização posterior e muito demorada e cara para ser elaborada, dado o elevado número de enquetes que seriam necessárias. A grande maioria dos estudos regionais representam a diversidade em um número que oscila de oito a vinte tipos. Esta é uma regra empírica que se impõe independentemente dos efetivos e da variabilidade da população pesquisada.

Por outro lado, cada indivíduo pesquisado deve poder ser classificado em um ou mais tipos com uma aproximação razoável. Este princípio é de difícil conciliação na prática, com a regra precedente, pois a variabilidade intra tipo depende bastante do número de tipos, o qual pode variar em um intervalo relativamente estreito. A aproximação média que acompanha as decisões de classificar um estabelecimento em um dado tipo são assim muito variáveis entre tipologias e, no interior de uma mesma tipologia, segundo os tipos.

O caráter binário da decisão, pertencer ou não pertencer, impede avaliar a aproximação realizada em cada caso, e portanto distinguir um estabelecimento particularmente representativo do tipo daquele que foi situado no tipo por falta de melhor opção, o que dificulta a descrição do tipo e a análise do caso.

Os métodos tipológicos referido procedem por segmentações sucessivas da população de estabelecimentos agrícolas a classificar tomando atributos de tal ordem em seguida outros. Este procedimento leva a elaboração de árvores de classificação ou grades tipológicas mais ou menos complexas. Cada estabelecimento é atribuído, automaticamente a um tipo, porém esta classificação forçada não necessariamente tem significação real em relação ao funcionamento do estabelecimento. Outro inconveniente 
das grades tipológicas reside na não independência dos diferentes tipos, ou seja, é impossível modificar a definição de um deles e consequentemente sua composição, sem modificar pelo menos um outro tipo, o que não tem nenhuma justificativa real.

As enquetes diretas nas quais se baseiam os métodos tipológicos são exigentes em tempo, o que pode levar a organização de equipes grandes e custosas, ou a realizar uma amostragem insuficiente e portanto pouco representativa, ou ainda restringindo muito a região estudada.

As informações obtidas nas enquetes fornecem uma imagem instantânea e estática e privilegiam as variáveis estruturais mais fáceis de apreender que as variáveis dinâmicas e as práticas do dia a dia dos agricultores. O acompanhamento ao longo de um ciclo do sistema de produção possibilita uma compreensão mais fina da lógica do funcionamento.

Uma última ressalva diz respeito ao aproveitamento dos conhecimentos $\mathrm{e}$ informações acumuladas pelos diversos organismos de apoio a agricultura e pelos técnicos locais. A incorporação e análise destas informações e destes conhecimentos implicam em criar um dispositivo de pesquisa que facilite o diálogo com os técnicos e organismos locais, o que nem sempre é evidente. 


\section{PROPOSIÇÃO METODOLÓGICA}

A proposição metodológica que nesta seção será detalhada se destina aos engenheiros agrônomos que tem na atividade de orientação técnica e gerencial sua principal função. Estes profissionais são confrontados a diversidade de estabelecimentos agrícolas e de meios físicos e por esta razão devem adaptar a cada caso as preconizações técnicas

Para adaptar os conselhos técnicos é necessário conhecer a diversidade de maneiras de produzir dos agricultores. Propõe-se um método de estudo da diversidade regional dos estabelecimentos agrícolas baseado no estudo do funcionamento do conjunto família/sistema de produção.

A finalidade do método é diagnosticar os principais problemas de natureza agrotécnica ou gerencial enfrentados ao nível do processo produtivo, buscando a partir do diagnóstico adequar as recomendações as situações específicas..

Os dois pressupostos do método são:

1) a abordagem global do estabelecimento permite apreender os problemas técnicos enfrentados pelos agricultores e determinar as melhorias/inovações mais adaptadas, quer dizer, passíveis de serem adotadas no contexto do estabelecimento;

2) é possível classificar os estabelecimentos de uma região em tipos que se comportam de forma relativamente homogênea em relação a conduções técnicas e que podem adotar as mesmas melhorias/inovações. 
O método é composto de dois instrumentos : o guia de estudo e a orientação para a construção da tipologia. O guia de estudo é o instrumento de enquete e organização do diagnóstico global de cada unidade de produção amostrada. A tipologia consiste na modelização da diversidade de maneiras de produzir existente em uma região. O guia de estudo é apresentado sob forma de questionário e a orientação para a construção da tipologia é descrita através de suas fases de operacionalização.

O objetivo é apresentar os princípios metodológico e descrever os procedimentos utilizados para a realização do diagnóstico e da tipologia, de maneira suficientemente clara para que os engenheiros agrônomos de campo possam aplica-los, adapta-los e tirar ensinamentos para as ações de desenvolvimento

\subsection{O diagnóstico global : princípios metodológicos}

O diagnóstico do estabelecimento agrícola é fundamentado na abordagem global do processo produtivo.

A abordagem global considera o estabelecimento agrícola como um sistema finalizado pelos objetivos do agricultor e de sua família confrontados a um conjunto de condicionantes internos e externos. A associação dos dados atuais e passados permite apreender o funcionamento do estabelecimento e definir a trajetória que seguiu de um estado anterior para o atual.

O funcionamento consiste no encadeamento de decisões tomadas no interior de um conjunto de condicionantes com a finalidade de atingir um ou vários objetivos de produção. A ação que engendram estas decisões intervem sobre os diversos 
fluxos (de dinheiro, de trabalho, de materiais, de informação) no seio do estabelecimento, e deste com o contexto sócio-econômico. Fluxo e encadeamento de decisões são os dois componentes do funcionamento do estabelecimento agrícola.

As decisões refletem os objetivos do centro de decisão, seja este o agricultor e sua familia em uma unidade familiar de produção, seja um empresário no caso de uma empresa agrícola. Para facilitar denomina-se este centro de decisão de empreendedor.

Os objetivos, no quadro dos quais ocorrem as decisões, estruturam-se de forma hierárquica. Um primeiro nível de objetivos corresponde as orientações gerais definidas para o estabelecimento e no qual os objetivos do empreendedor intervém fortemente. Estes objetivos dizem respeito de uma parte, as expectativas do empreendedor em relação a unidade de produção (por exemplo, nível de renda, qualidade de vida, posição social), e de outra parte o que pretende fazer a longo prazo em sua atividade (as transformações do sistema de produção, a herança para os sucessores, etc).

Para satisfazer estes objetivos gerais o agricultor faz um certo número de escolhas, que são : as atividades produtivas que explora, o nível de intensificação que adota, especialização ou diversificação, o grau de mecanização, a utilização de recursos próprios e/ou externos, a transformação dos produtos, a evolução prevista do aparelho produtivo a médio prazo. O conjunto destas escolhas correspondem a maneira através da qual o agricultor espera alcançar seus objetivos no contexto que se encontra, é denominada de decisões estratégicas.

As decisões estratégicas induzem um certo funcionamento que se reflete na escolha do tipo de sucessão de cultura, de sistema de preparo do solo, de manejo dos 
animais, de manejo da fertilidade do solo, etc. O conjunto de decisões que envolvem estes aspectos do funcionamento, são denominadas de decisões táticas.

A realização concreta das operações que foram definidas nos níveis anteriores exigem elas mesmas decisões específicas, são as decisões técnicas. Estas decisões correspondem a escolhas, como : data precisa do preparo do solo, dos reprodutores, de herbicidas, da quantidade efetiva de alimento fornecida aos animais, etc.

O empreendedor reflete, calcula e fixa seus objetivos considerando o meio englobante e sua história. Ao longo do tempo, os resultados obtidos e as dificuldades enfrentadas colocam em questão não apenas o sistema de produção adotado como também certos objetivos gerais.

Apreender o estabelecimento como um sistema implica em postular que o agricultor ajusta permanentemente estes três níveis de objetivos coerentemente. A coerência, neste caso, é do ator/agricultor, com seus objetivos e a percepção de sua situação e do contexto social e econômico. O postulado de coerência deve ser considerado como um modelo de análise do estabelecimento e um princípio metodológico : a análise termina apenas quando a coerência fica evidenciada.

O procedimento deve permitir que esta coerência seja acessível a um observador externo, o técnico. O diagnóstico desta coerência se apoia sobre um duplo julgamento : interno, ponto de vista do agricultor, e externo, do técnico.

O contexto social, econômico e ambiental da unidade de produção, sua história e o aparelho produtivo disponível intervêm como potencialidade, ou como elemento neutro ou ainda como restrição, no funcionamento da unidade. O caracter 
positivo ou limitador destes componentes é julgado em relação aos objetivos e estratégias adotadas.

A história do estabelecimento e do empreendedor influenciam seus objetivos, suas estratégias e a fixação do sistema de produção. O estudo da história auxilia à compreensão do funcionamento atual do estabelecimento e esclarece os mecanismos pelos quais se chegou a esta situação. Esta informação permite traçar sua trajetória de evolução.

A trajetória de evolução é composta de etapas ao longo das quais o funcionamento permanece igual, e de modalidades de passagem de uma etapa a outra ligadas as mudança de objetivos, ou a modificações dos meios de produção, ou de transformações do contexto social e econômico, ou ainda da interação destes elementos.

O diagnóstico global não se restringe a descrição do funcionamento do conjunto empreendedor/sistema de produção, incluí o julgamento. $O$ julgamento comporta três aspectos :

a) verificar a adequação entre a maneira de produzir e os objetivos do agricultor, a curto, médio e longo prazo. Trata-se de examinar e julgar a coerência entre objetivos buscados e ações observadas seguindo o ponto de vista do proprio agricultor;

b) avaliar as as performances das atividades produtivas e a eficiência das tranformações. Trata-se do julgamento do ponto de vista do técnico,.As referências utilizadas podem ser locais, se existentes, ou métodos inspirados na análise de grupo. A avaliação é setorial;

c) a reprodutibilidade global, isto é, do conjunto família/sistema de produção, é abordado de três maneiras complementares - a reprodutibilidade agronômica, a reprodutibilidade do trabalho e a reprodutibilidade econômica. 
O estudo da reprodutibilidade agronômica comporta o balanço da fertilidade (estoque de elementos minerais e de matéria orgânica no solo), o estado físico do solo (erosão, compactação), a detecção da presença anormal de plantas invasoras e de insetos nocivos, também fazem parte do estudo.

À reprodutibilidade do trabalho é importante em certos sistemas de produção que exigem uma grande quantidade de trabalho, tanto familiar como assalariada. Estes dois grupos de forças de trabalho estão em constante evolução envelhecimento do chefe do estabelecimento, saída de um filho, escassez de mão de obra local,etc - de tal forma que a questão da reprodutibilidade da mão de obra deve ser considerada para a manutenção. do sistema de produção

$\mathrm{O}$ estudo da reprodutibilidade econômica deve se deter nos indicadores que são mais acessíveis na enquete, não podendo assim ser muito detalhados. Os indicadores devem permitir estimar a saúde econômica e financeira do estabelecimento. Os resultado econômicos e financeíros utilizados como medida são aqueles que podem ser calculados a partir das informações das produções obtidas e dos itinerários técnicos registrados (produto bruto, custo de produção, renda agrícola, margem bruta). As maneiras de julgar a reprodutibilidade variam de acordo com os objetivos do empreendedor. Há empreendedores em que o lucro é o critério determinante, outros em que a instalação de um sucessor é o que importa.

Um sistema de produção é dito reprodutível quando seu funcionamento durante um determinado período permite que o conjunto do aparelho de produção e dos insumos usados se renove, mantendo o sistema em funcionamento no período seguinte, no caso das unidades familiares de produção. Já para o caso das empresas agrícolas as exigências são mais amplas. 
A reprodutibilidade é uma condição necessária mas não suficiente para manter o sistema. O sistema de produção deve continuar a satisfazer os objetivos do agricultor e de sua família e ser capaz de acompanhar a evolução tecnológica e econômica do meio cincundante

\subsection{Operacionalização do procedimento : guia de estudo do conjunto} família/sistema de produção

O levantamento das variáveis de estrutura, das ações e sua correspondência em fatos, que podem ser verificados em parte no estabelecimento, é realizada através de uma entrevista com o agricultor e/ou sua família. O instrumento que orienta a coleta de dados e seu tratamento visando o diagnóstico é o guia de estudo. O guia de estudos se encontra ao final desta seção de proposição metodológica.

Ao gerar e agrupar as diversas informações evidencia-se as contradições ou as convergências que revelam o processo de tomada de decisão. Por esta razão o guia de estudo dá uma lista de dados a obter, reunidos em algumas rubricas e modalidades de agrupamento. Estes dados são tratados e as informações resultantes são utilizadas em sínteses por rubrica e em sínteses de diversas rubricas.

Apesar do guia parecer bem codificado e fechado, ele não precisa, necessariamente, ser o guia da entrevista e mesmo da cronologia da coleta dos dados. O guia contém uma maneira de transcrever os dados coletados e uma forma de tratá-los. O desenrolar da entrevista e a formulação de questões ficam por conta do utilizador, que no entanto deve respeitar certas etapas na análise. 
Para que o entrevistador possa aplicar bem o procedimento e fazer as sínteses requeridas é necessário que conheça suficientemente a abordagem. Deste modo, uma formação de cinco dias, comportando a apresentação da abordagem, do procedimento prático e de duas aplicações no terreno, permite aos engenheiros agrônomos adquirir domínio sobre o método.

A organização do guia parte da constatação de que os técnicos estão acostumados a fazer diagnósticos setoriais, em geral desconectados do funcionamento do sistema de produção e dos objetivos do empreendedor. Esta constatação conduziu a separação do diagnóstico em três etapas. O diagnóstico habitual do técnico, diagnóstico setorial, é precedido de uma etapa de constatação e síntese sem julgamento de parte do técnico evidenciando o funcionamento do conjunto família/sistema de produção.Seguese uma última etapa que permite hierarquizar e situar os diagnósticos setoriais no seio do funcionamento do estabelecimento evidenciado na primeira etapa.

O diagnóstico global se desenvolve portanto em três etapas sucessivas, que se materializam nas três partes do guia.

A primeira etapa corresponde a apreensão do funcionamento do conjunto do estabelecimento, a partir da evidenciação das escolhas estratégicas e de seus determinantes.

Inicia-se por caracterizar o estabelecimento por sua dimensão e suas atividades produtivas, chegando-se a definir a combinação de atividades, o que comporta:

- o inventário das atividades vegetais e animais, classificando-as segundo sua importância em superfície, em quantidade de produção gerada, insumos 
consumidos, sua valorização pela transformação ou organização de uma circuito de comercialização e por seu produto bruto;

- a descrição do manejo das culturas e dos animais, a intensidade de utilização de insumos, rendimentos ou performances animais, nível de custos de produção e de margens brutas.

O postulado básico para evidenciar a coerência do funcionamento; é de que esta nas escolhas que levam a combinação de atividades o essencial das decisões estratégicas.

Em seguida, cada rubrica - familia, aparelho de produção (terra, equipamentos e benfeitorias), contexto e história - estudado, é analisado sob dois ângulos

- suas relações com a combinação de atividades : procura-se compreender por que certas características orientam, limitam ou aumentam a gama de atividades presentes no estabelecimento, os modos de condução adotados e suas performances técnicas e econômicas;

- as decisões passadas ou atuais que ela revela : certas características que traduzem escolhas importantes que ultrapassam o quadro da combinação de atividades e dizem respeito à gestão do estabelecimento, por exemplo, mudanças do aparelho de produção, das formas de financiamento, da constituição do patrimônio.

A partir do conhecimento do projeto da família e sua posição em relação aos resultados econômicos do estabelecimento, faz-se uma recapitulação das diferentes relações e decisões detectadas com a finalidade de apreender a coerência das escolhas estratégicas. 
Finalmente, elabora-se uma representação, sob forma de um esquema de funcionamento, que recapitula:

- a situação da família e de seus objetivos gerais;

- as escolhas estratégicas apreendidas, ou seja, a orientação atual do sistema de produção determinado pelos objetivos da família e pelos características do aparelho de produção;

- a dimensão do estabelecimento;

- as potencialidades e restrições do aparelho de produção e do contexto do estabelecimento, não modificáveis atualmente pelo agricultor e determinantes das escolhas estratégicas;

- os resultados técnico-economicos obtidos e, se for caso, as melhorias desejadas pelo agricultor e sua família;

A segunda etapa diz respeito ao funcionamento técnico e a análise dos resultados e dos processos de produção. Trata-se do diagnóstico setorial.

Ao final da etapa precedente, pode-se avaliar a importância de um ou vários setores do estabelecimento, seja atividades de produção animal ou vegetal, seja aspectos da organização do trabalho ou da gestão econômica e financeira. Escolhe-se alguns setores privilegiados que serão então :

- caracterizados, detalhando-se os processos de produção, descrevendo-se as práticas e realizando os balanços específicos dos subsistemas;

- em seguida são julgados independentemente do agricultor, ou seja, referidos aos conhecimentos, métodos e inndicadores próprios às disciplinas técnicas e econômicas envolvidas; 
A escolha dos setores a aprofundar está subordinado ao tema geral que justificou o estudo do estabelecimento e que pode eventualmente exigir o aprofundamento de certas partes não tratadas suficientemente na primeira etapa.

O estudo e o julgamento das práticas permite, de outra parte, revelar o referencial técnico e a percepção que o agricultor tem dos condicionantes de seu estabelecimento.. Deste modo, a observação dos condicionantes do meio físico pode ser apreciado através da localização das culturas ou da diferanciação da condução segundo os terrenos; do mesmo modo, a importância dos condiconantes do trabalho podem ser percebidos através do calendário de utilização da mão de obra, a aquisição de equipamentos, como também pelas modificações realizadas ao nível das técnicas culturais.

Para executar esta etapa, o guia está organizado em quatro capítulos: manejo dos animais, manejo das culturas, organização do trabalho, renda e capacidade financeira..

$\mathrm{O}$ funcionamneto do estabelecimento e as proposições de melhorias constituem a terceira etapa.

Confronta-se nesta etapa a análise e/ou julgamento dos resultados dos processos de produção com a visão do estabelecimento percebida inicialmente na primeira etapa. Esta síntese é então formalizada em um esquema que comporta:

- uma confirmação ou uma modificação da formulação das escolhas estratégicas e de seus determinantes, tais como foram apresentados ao final da primeira parte, antes dos diagnósticos setoriais;

- um diagnóstico e a demonstração dos problemas do estabelecimento com as proposições, se for o caso; 
- a sinalização da importância para o funcionamento do estabelecimento das ações concernentes aos sub-sistemas, ou organização do trabalho, caixa,etc.

O guia pode ser utilizado para diferentes operações de desenvolvimento que envolvem o estabelecimento agrícola. O objetivo do estudo determina o modo do uso do guia.

Se o objetivo for conhecer de forma geral o estabelecimento, sem um objetivo específico de ordem técnica, é possível utilizar apenas a primeira parte do guia. Organismos como as cooperativas ou escritórios regionais de extensão podem utilizar deste modo o guia para fazer um diagnóstico preliminar da situação dos agricultores e dos sistemas de produção existentes em uma região, para, a partir daí, definir os grandes linhas de sua ação. A aplicação em uma amostra de estabelecimentos permite construir uma tipologia gerais dos sistemas de produção da região..

Para compreender o funcionamento do sistema de produção e verificar o interesse de uma ação técnica determinada, utiliza-se a primeira parte e um ou vários capítulos da segunda parte, em conformidade a ação desejada. A terceira parte permite efetuar uma síntese parcial e em particular verificar o interesse da intervenção técnica projetada para o funcionamento.

Para um diagnóstico completo do funcionamento e proposições de melhoria utiliza-se todas as partes e capítulos do guia. Para um diagnóstico técnico setorial situada no contexto do conjunto do estabelecimento utiliza-se a primeira parte e os capítulos da segunda parte julgados importantes para o estabeleciemnto estudado e concernentes a questão técnica formulada. A síntese se fará graças ao esquema final da terceira parte. Esta situação corresponde a realização de tipologias de estabelecimentos a 
partir de um ponto de vista técnico e econômico, conforme será apresentado em seguida no ítem 4.3. .

\subsection{Modelização da diversidade regional dos sistemas de produção : a tipologia de funcionamento e as trajetórias de evolução}

O diagnóstico global, descrito e operacionalizado pelo guia de estudo, fornece um conjunto de conhecimentos sobre o funcionamento dos estabelecimentos de uma região. A partir destes conhecimentos é elaborada uma classificação dos estabelecimentos em tipos que apresentam características comuns de funcionamento e que podem receber o mesmo tratamento em termos de ações de desenvolvimento.

As tipologias são úteis para os organismos de desenvolvimento, pois permitem:

- caracterizar a diversidade de estabelecimentos em um espaço geográfico e desta maneira orientar as prioridades de seus programas de ação e de estudo;

- tratar de um tema técnico preciso situando-o no contexto dos estabelecimentos e assim prever as soluções possíveis;

Para os dois casos acima propõe-se a mesma análise de funcionamento, procedimentos de enquete e de construção de tipos idênticos. Entretanto convém examinar com cuidado a utilização de tipologias construídas para uma finalidade específica e depois usá-la para outros objetivos, pois a amostragem e mesmo a definição dos parâmetros para agrupar em tipos podem ser bastante distintos. Por esta razão que se faz necessária uma reflexão prévia visando formular o problema e explicitar as escolhas dos domínios de estudo e da amostragem a ser realizada. Assegura-se assim o domínio de 
validade do estudo realizado e define-se as possibilidades de sua utilização posterior para outros fins.

Estas exigências implicam em um estudo preliminar a realização das enquetes, do contexto regional e de outras fontes de informação sobre os estabelecimentos, organizando-as segundo o objetivo perseguido e de acordo com a diversidade regional constatada inicialmente.

A construção da tipologia consiste em duas operações:

- reagrupar os estabelecimentos a partir de seus funcionamentos, sob forma de tipos;

- revelar as trajetórias de evolução dos tipos;

A construção dos tipos se faz a partir dos esquemas de funcionamento produzido na primeira etapa do estudo da amostra dos estabelecimento. Os estabelecimentos são reagrupados segundo suas características, objetivos e estratégias do sistema de produção. A criação do tipo resulta da comparação das situações observadas segundo um esquema de análise, o que dá origem a uma definição de um esquema de funcionamento do tipo.

O mesmo procedimento de agrupamento é aplicado para descrever as trajetórias. As trajetórias são construídas a partir dos dados da história individual dos estabelecimentos e das informações sobre a evolução da região considerada. As informações secundárias são interpretadas, como fatores decisivos, tendo em vista a concepção que inicialmente foi dada ao funcionamento e a evolução dos sistemas de produção. 
Para o conjunto dos estabelecimentos pesquisados, define-se critérios ou indicadores, que dão conta dos diversos sistemas atuais e das evoluções passadas. Estes indicadores são a base de uma primeira classificação realizada a título de hipótese de trabalho. Em seguida esta classificação é testada e modificada até que se é capaz de :

- escolher os critérios de funcionamento atual que permitem reunir os estabelecimentos que constituem um tipo;

- reunir os estabelecimentos segundo suas trajetórias identificando as etapas comuns da evolução passada e descobrir ao nível regional as principais trajetórias que representam um processo evolutivo coerente;

- situar cada estabelecimento em uma trajetória e em um tipo.

Em um segundo momento é feito a extrapolação quantitativa de cada tipo de funcionamento, sua importância na região de estudo.

\subsection{Os procedimentos para construir a tipologia e as trajetórias de evolução}

A região de estudo é limitado pelo problema colocado ou do tema técnico estudado, os meios materiais e humanos disponiveis, enfim deve ser objeto de uma reflexão preliminar dos organismos de desenvolvimento envolvidos.

Para limitar o número de enquetes sem deixar de explorar a gama de estabelecimentos existentes na zona de estudo, é usada a amostragem estratificada. Para isto faz-se um estudo preliminar visando levantar as diferentes categorias de estabelecimentos presentes e os elementos do ambiente que podem afetá-los. Utiliza-se de dados secundários (mapas de solo, geográficos, estatísticas), estudos anteriores, entrevistas com pessoas chaves (dirigentes, extensionista, pioneiros,..) e visitas para conhecer a paisagem. 
Estes dados e informações são então organizados para fazer uma dupla estratificação:

- estratificação do meio físico e do contexto sócio-econômico chegandose a algumas classes observáveis em um mapa;

- estratificação dos estabelecimentos sobre critérios de tamanho e de atividades.

Após se faz um cruzamento destas duas estraficações resultando em classes de caráter geral. Os critérios usados e a precisão requerida para esta classficação prelimnar variam segundo:

- a região: diversidade de meios e possibilidade de identificar as zonas geográficas correspondentes;

- o nível de conhecimentos facilmente acessíveis existentes sobre a região;

- os objetivos de estudo que incitam a valorizar certos parâmetros do meio ou dos estabelecimentos e contribuem assim a precisar a gama de sistemas ou de meios a considerar.

As classes obtidas a partir do cruzamento Meios X Estabelecimentos, são apresentadas aos técnicos que atuam na região visando discutir a variabilidade no interior de cada classe e a existência/significação, o que permite definir o número de enquetes a serem feitas.

$\mathrm{O}$ estudo preliminar desemboca em uma tabela de contingência Meios X Estabelecimentos da qual serão estudadas apenas algumas classes, explicitando-se as razões para tal e as hipóteses correspondentes. Estas classes e as respectivas hipóteses definem o domínio de validade do estudo. 
A partir daí são escolhidas as localidades que parecem ser respresentativas das classes definidas ou caso não se possa detectar uma relação entre as localidades e as classes, escolhe-se zonas identificadas como homogêneas nos mapas produzidos.

A escolha dos estabelecimentos a serem estudados em cada localidade ou zona selecionada é realizada a partir de uma lista destas com suas respectivas características, confeccionada com os dados fornecidos pela linha de leite e pessoas que conhecem os agricultores da localidade escolhida. As características mencionads são idade do chefe de família, número de membros da família, tamanho da unidade produtiva, produções realizadas, estatuto jurídico.

O número de estabelecimentos a serem estudados em cada localidade ou zona homogênea pode ser estabelecido a priori ou se realiza um determinado número de enquetes e se faz a análise identificando em uma primeira aproximação tipos de funcionamento e se for notado que estes estão se repetindo finda-se as enquetes nesta localidade. A experiência tem mostrado que uma boa estraficação em classes permite a realização de um número relativamente pequeno de enquetes mas representativa do total dos efetivos da localidade. O importante é buscar a variabilidade no interior das classes.

Cada enquete comporta a abordagem do funcionamento do conjunto de estabelecimento e se for o caso uma parte específica ligada ao tema em estudo com os diagnósticos correspondentes. Assim os documentos a disposição do pesquisador são o guia, fichas de síntese e as fichas de enquete e de síntese concernentes ao tema específico. 
Após e/ou concomitantemente ao trabalho de campo inicia-se o reagrupamento dos estabelecimentos em tipos. O procedimento consiste em a partir dos estratos de amostragem precisar gradativamente os tipos graças aos dados das enquetes em seguida utiliza-los como estrutura de comparação.

Em um primeiro momento afina-se os estratos definidos inicialmente como classe, utilizando-se os dados recolhidos pela enquete. Pode-se assim visualizar as classes homogêneas do ponto de vista das dimensões e produções, introduzindo hierarquias entre estas últimas segundo critérios de importância em superficie ou volume de negócios.

Esta classificação pode ser cruzada com a estratificação do meio, também melhorada com os dados de enquete, resultando em hipóteses sobre a localização das classses e sua relação com o meio. Do mesmo modo pode ser cruzado classes de superficie agrícola útil (SAU), mão de obra, equipamentos. Estes cruzamentos permitem afinar as classes e formular hipóteses sobre a distribuição dos sistemas de produção na região estudada.

Partindo de uma classe definida conforme o procedimento acima descrito, compara-se o funcionamento dos estabelecimentos e se reagrupa aqueles que tem estratégias e objetivos comparáveis. Em seguida analisa-se as classes próximas, localizando os estabelecimentos nos tipos já identificados ou criando novos.

Os tipos são definidos por suas estratégias e são descritos pelos valores modais de seu aparelho de produção, seus meios, suas performances econômicas e técnicas. Esta caracterização permite fazer comparações intra e inter tipos o que permite obter informações sobre a possibilidade de melhorias e os meios correspondentes necessários para executá-las. 
A partir das definições de estratégia e características do aparelho de produção, elabora-se uma chave de determinação dos tipos que comporta critérios simples capazes de situar todo estabelecimento da região em um tipo. Esta chave é testada em uma nova amostragem mais restrita, se for eficiente para enquadrar estes estabelecimentos pode ser estendida para o conjunto da região.

A estimação da importância dos tipos, necessária para avaliar a importância de um problema regional e os meios de operacionaliza-los, pode ser feita de duas maneiras:

- aplicação da chave aos dados de censo não apenas públicos mas também aos levantamentos realizados pelas cooperativas e Emater's;

- enquete rápida no seio das classes sobre a base de um questionário comportando os parâmetros da chave de determinação dos tipos de funcionamento.

Ao longo das enquetes vai se conformando as etapas do desenvolvimentos histórico dos estabelecimentos. Os dados coletados sobre a história de cada estabelecimento servem também para a construção das trajetórias. Estes dados mais as informações sobre a história da região, na qual se observa as grandes modificações, permitem apreender as lógicas que determinaram a emergência dos atuais tipos.

Para cada tipo compara-se as histórias respectivas dos estabelecimentos que o compõem e verifica-se se eles seguiram as mesmas etapas de evolução, remontando-as até o estado inicial do estabelecimento. Ao aplicar este procedimento em todos os tipos obtem-se as trajetórias de evolução, que podem ser representadas graficamente. 
4.5. Guia de estudo : instrumento de diagnóstico global da unidade de produção agrícola

Neste ítem é apresentado o guia utilisado para fazer a enquete direta da unidades de produção amostradas. Para facilitar seu manuseio foi feito um índice específico

Ao final do guia foram acrescentadas algumas fichas complementares que tem a finalidade de facilitar a coleta de dados que serão transcritas na segunda parte do guia. É dado um exemplo em relação a organização do trabalho, capítulo III da segunda parte. Outra fichas podem ser elaboradas para ajudar na transcrição de dados. 


\section{ÍNDICE}

Primeira Parte: Funcionamento da unidade de produção e apreensão das escolhas estratégicas e de seus determinantes

103

I - Identificação e localização

II - Estatuto do estabelecimento e das terras

III - As atividades produtivas : natureza e intensidade

IV - A família e seus objetivos

V - O aparelho de produção

A - As terras

B - A mão de obra

C - Máquinas, equipamentos e instalações

D - Contexto sócio econômico

E - Sintese geral do aparelho de produção

VI - História do estabelecimento

VII - As escolhas estratégicas e seus determinantes

VIII - O esquema de funcionamento

Segunda Parte: funcionamento técnico e elaboração de diagnósticos setoriais

II - O manejo das culturas e dos sitemas de cultivo

III - Organização do trabalho

IV - Renda e finanças

Terceira Parte : funcionamento do estabelecimento e proposições de melhorias 155 
PRIMEIRA PARTE : funcionamento da unidade de produção, apreensão as escolhas estratégicas e de seus determinantes 


\section{I - IDENTIFICAÇÃO E LOCALIZAÇ̃̃O}

Nome do Agricultor:

Localidade:

Município:

Referências para Comunicação:

Situação Geográfica (obtido a partir do mapa 1:50000 e comentários) 
II - ESTATUTO DO ESTABELECIMENTO E DAS TERRAS

A. Forma Jurídica do Estabelecimento:

B. Características Fundiárias

C -. Repartição da superfície do estabelecimento segundo os tipos de uso e segundo o estatuto jurídico das terras:

\begin{tabular}{|l|l|l|l|l|l|}
\hline Tipo de Uso & Área & \% Próprio & \% Arrendado & \% Outros & \% Sup. Total \\
\hline $\begin{array}{l}\text { Terra cultivada } \\
\text { Pastagem natural } \\
\text { Horta/Pomar }\end{array}$ & & & & & \\
\hline TOTAL(= SAU) & & & & & \\
\hline $\begin{array}{l}\text { Mato } \\
\text { Não Agricola }\end{array}$ & & & & & \\
\hline Superficie Total & & & & & \\
\hline $\begin{array}{l}\text { Superficie c/ } \\
\text { Correção pH }\end{array}$ & & & & & \\
\hline $\begin{array}{l}\text { Superficie irrigada } \\
\text { Superficie drenada }\end{array}$ & & & & & \\
\hline
\end{tabular}

Indicar:

- O número de proprietários e suas relações de parentesco eventuais com o agricultor.

- Os custos fundiários. 
III - AS ATIVIDADES PRODUTIVAS : natureza e intensidade

\section{A. Atividades de Produção Vegetal}

1. Superficies e destinação dos produtos no ano (da entrevista)

\begin{tabular}{|c|c|c|c|c|c|c|c|}
\hline \multirow[t]{2}{*}{ CULTURAS } & \multirow{2}{*}{$\begin{array}{c}\text { Superficie } \\
\text { (ha) }\end{array}$} & \multirow{2}{*}{$\begin{array}{c}\text { SAU } \\
\%\end{array}$} & \multirow{2}{*}{$\begin{array}{r}\text { TC } \\
\% \\
\end{array}$} & \multicolumn{4}{|c|}{ Destinação dos Produtos } \\
\hline & & & & $\mathrm{C}$ & $\mathrm{F}$ & A & AV \\
\hline a) T.C. & & & & & & & \\
\hline Total T.C. & & & & & & & \\
\hline $\begin{array}{l}\text { b) Pastagem } \\
\text { Natural }\end{array}$ & & & $\begin{array}{l}|/||||||||||||| \\
|/||||||||||| \mid\end{array}$ & & & & \\
\hline c) Horta/Pomar & & & ||||||||||||||| & & & & \\
\hline S.A.U. & & 100 & $|1 / 1|||||||||||$ & & & & \\
\hline
\end{tabular}

$\mathrm{C}=$ comércio $; \mathrm{F}=$ alimentação animal $\mathrm{A}=$ autoconsumo; $\mathrm{AV}=$ adubação verde Proporções em \% :

- Terra Cultivada (TC) / Superfície AgrÍcola Útil (SAU)

- Superficie Forrageira Cultivada(SFC) / SAU e Superficie Forrageira Total(SFT) / SAU

- Culturas de anuais de crescimento na pimavera-verão e de outono-inverno / SAU 
2. Variabilidade interanual da ocupação das terras

A ocupação das terras registradas anteriormente é representativa dos últimos três anos e corresponde ao uso dos próximos três anos? Se não, indicar as principais variações:

Situar as culturas e pastagem natural permanente, indicando as razões alegadas pelo agricultor

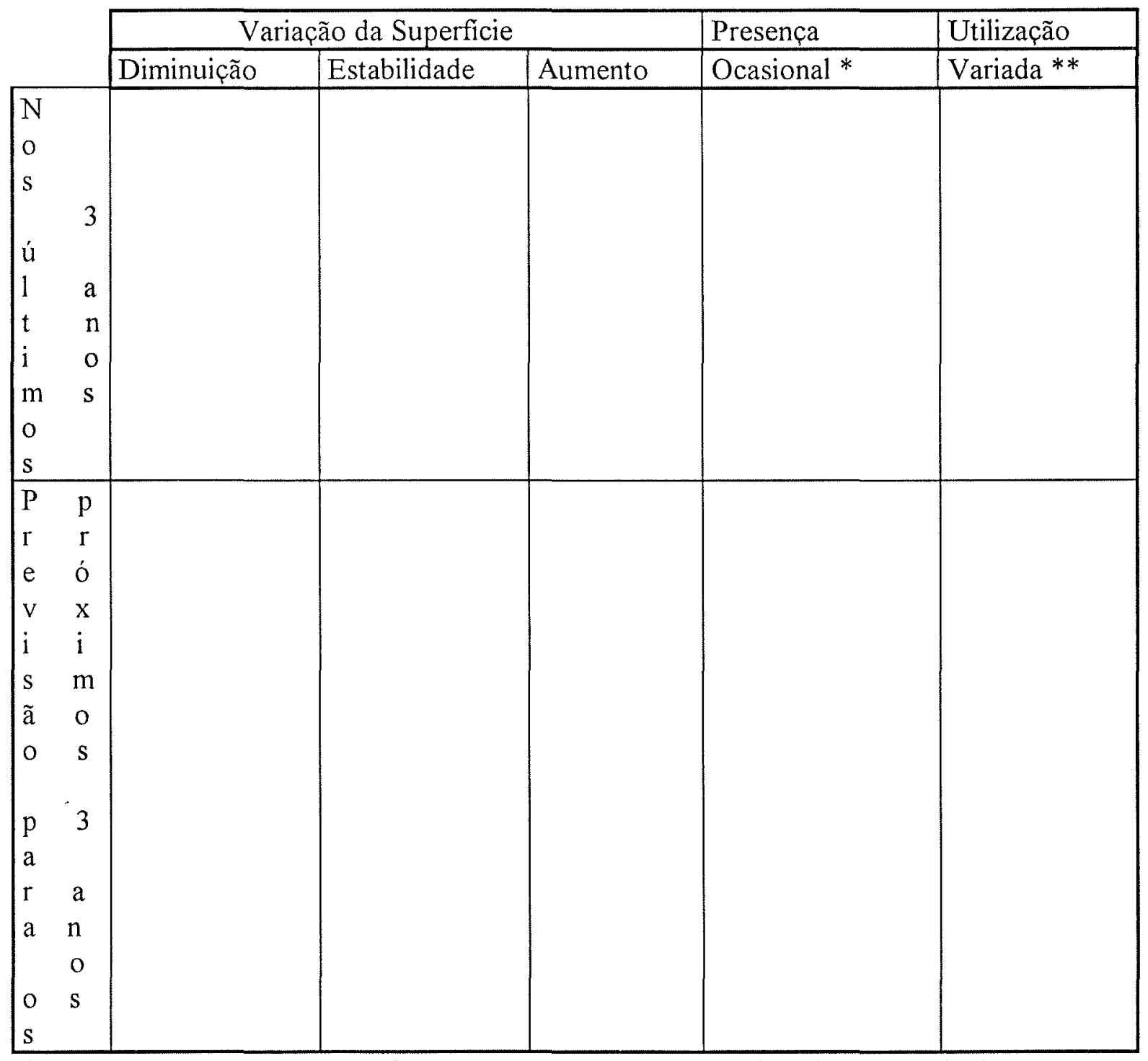

* Culturas não presentes na safra em curso, porém não abandonada pelo agricultor ** Culturas que seu uso pode variar de um ano para outro (comercialização e/ou forrageamento, etc). 
3. Valorização da produção vegetal

Indicar e descrever as operações visando transformar estes produtos, obter qualidade e preços especiais:

a) Produtos Vegetais Comercializados

\begin{tabular}{|c|c|c|c|c|c|c|}
\hline \multirow[t]{2}{*}{$\begin{array}{l}\text { Culturas } \\
\text { (esp. Vegetais) }\end{array}$} & \multicolumn{3}{|c|}{$\begin{array}{l}\text { Nível de Produções } \\
\text { (rendimento fisico) }\end{array}$} & \multicolumn{3}{|c|}{$\begin{array}{l}\text { Indicadores de Condução } \\
\text { Nivel médio de emprego de } \\
\text { insumos e custos operacionais }\end{array}$} \\
\hline & $\begin{array}{l}\text { Última } \\
\text { Safra }\end{array}$ & $\begin{array}{l}\text { Média das } \\
\text { safras } \\
\text { precedentes }\end{array}$ & $\begin{array}{l}\text { Produto } \\
\text { Bruto/ha }\end{array}$ & Insumos & Custos/ha & $\begin{array}{l}\mathrm{MB} / \mathrm{ha} \\
\text { Veg.com. }\end{array}$ \\
\hline & & & & & & \\
\hline & & & & & & \\
\hline & & & & & & \\
\hline & & & & & & \\
\hline & & & & & & \\
\hline & & & & & & \\
\hline & & & & & & \\
\hline & & & & & & \\
\hline & & & & & & \\
\hline & & & & & & \\
\hline & & & & & & \\
\hline & & & & & & \\
\hline
\end{tabular}

* Insumos: Sementes, adubos, pesticidas 
b) Produções vegetais utilizadas pelas criações

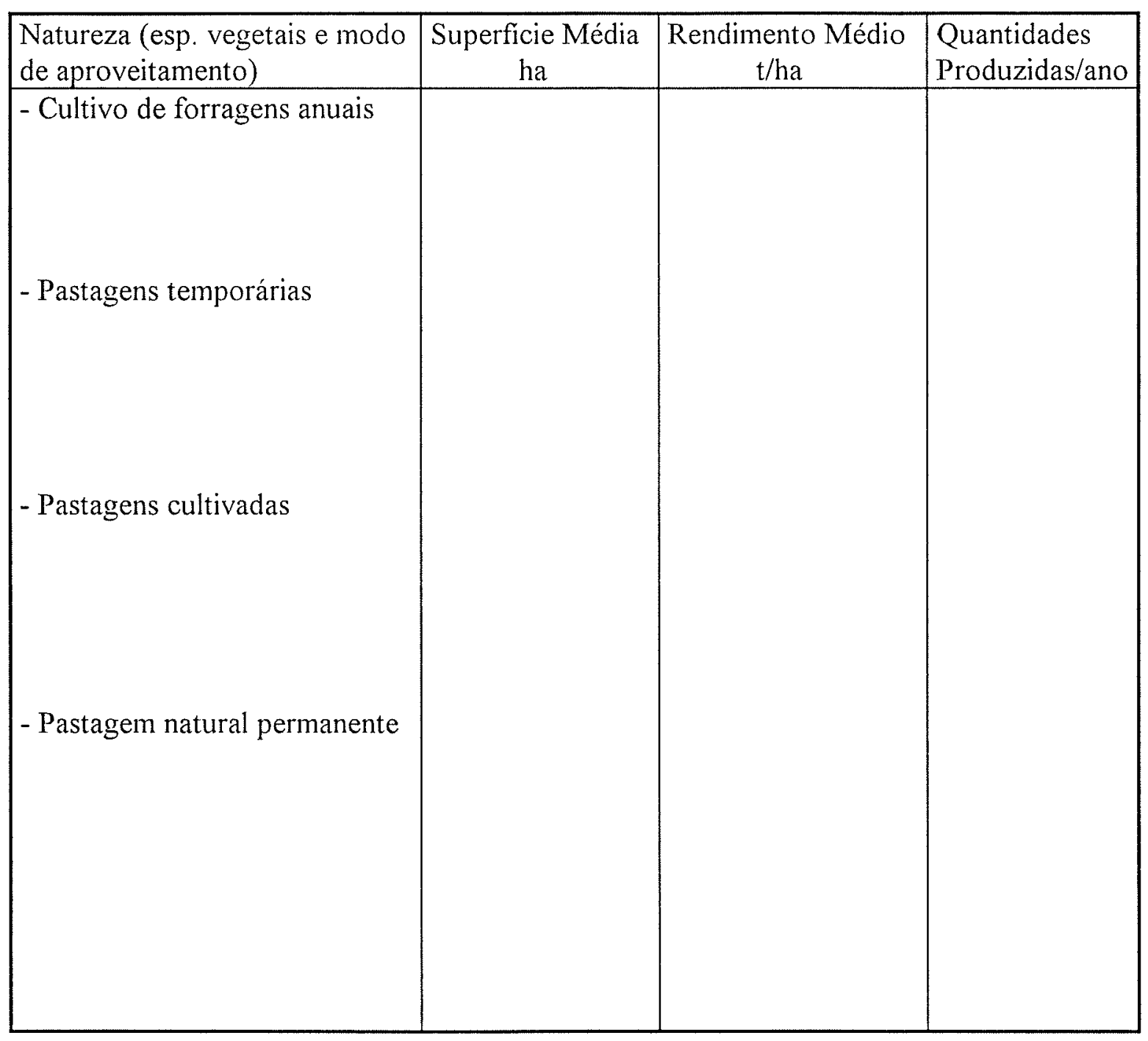

c) Autoconsumo familiar de produtos vegetais:

\begin{tabular}{|l|l|l|}
\hline Natureza dos Produtos & Quantidades Consumidas/ ano & Valor Estimado \\
\hline & \multicolumn{2}{|l|}{} \\
& & \\
& & \\
\hline
\end{tabular}




\section{B - Produções Animais}

1. Criações e produções

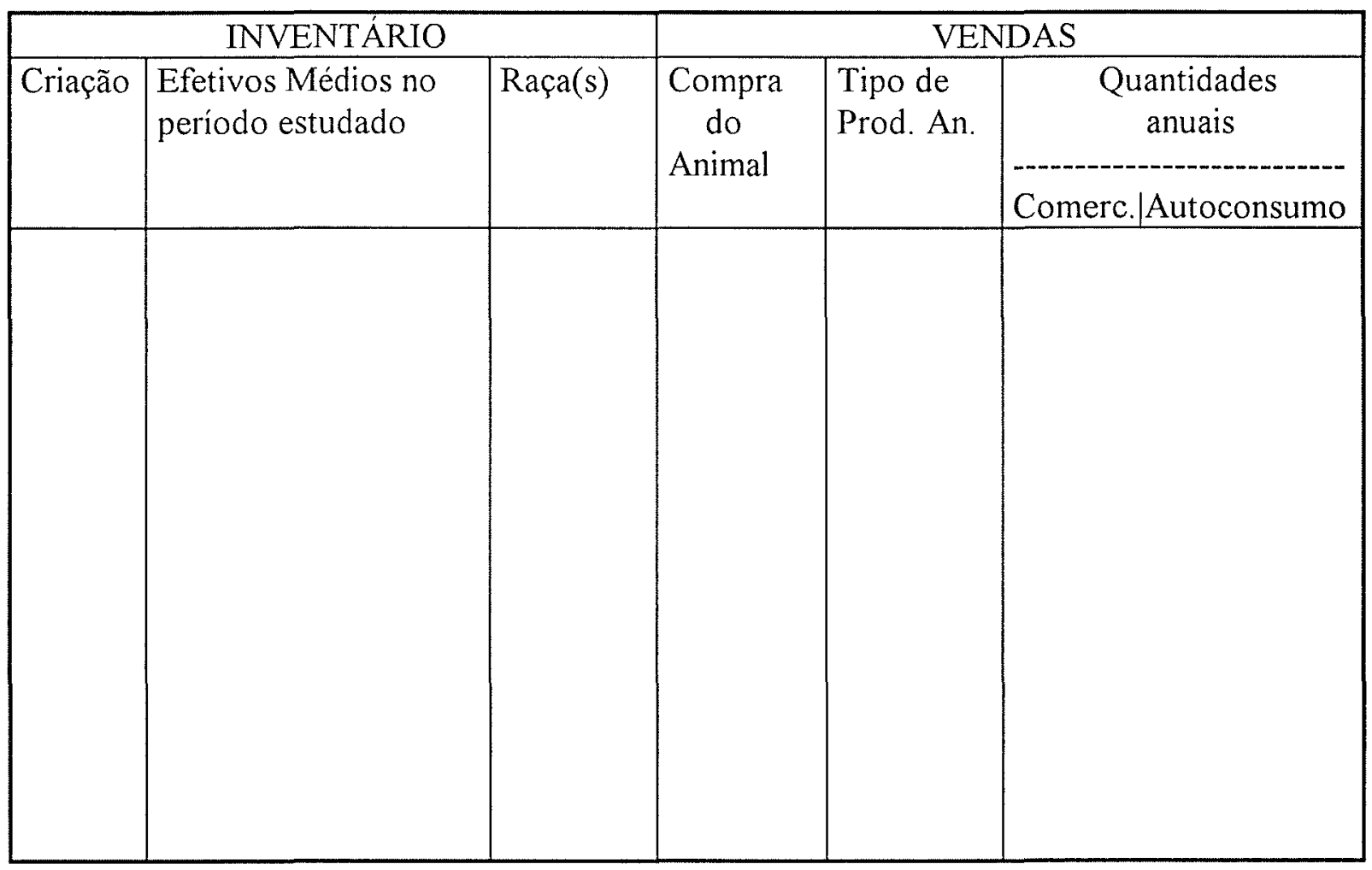


2. Evolução recente e provável das criações e produtos.

Situar as criações e produtos, indicando as razões alegadas pelo agricultor

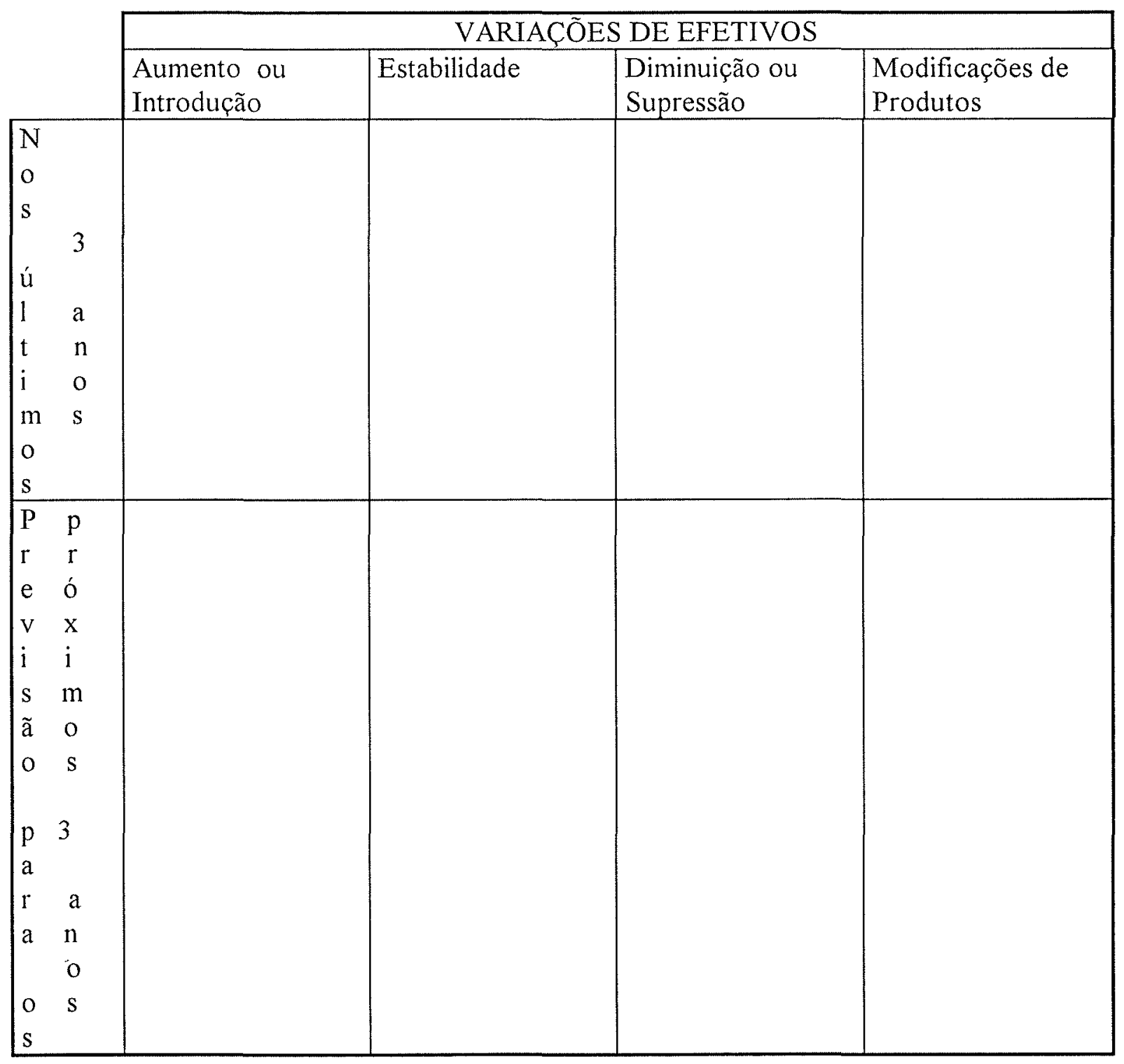

3. Valorização dos produtos animais

- Indicar e descrever as operações visando transformar estes produtos, obter qualidade e preços especiais 
a) Produtos comercializados. Indicar a produção comercializada por atividade animal, as unidades de medida correspondentes, o produto bruto,os custos por atividade.e as respectivas margens bruta $(\mathrm{MB})$.

\begin{tabular}{|c|c|c|c|c|c|c|}
\hline $\begin{array}{l}\text { Atividade } \\
\text { (espécies) }\end{array}$ & Último ano & $\begin{array}{c}\text { Média } \\
\text { anos } \\
\text { precedentes }\end{array}$ & $\begin{array}{l}\text { Produto } \\
\text { Bruto/Ativi } \\
\text { dade. }\end{array}$ & Insumos* & $\begin{array}{l}\text { Custos/ } \\
\text { Atividade }\end{array}$ & $\begin{array}{c}\text { MB / } \\
\text { Atividade }\end{array}$ \\
\hline & & & & & & \\
\hline & & & & & & \\
\hline & & & & & & \\
\hline & & & & & & \\
\hline & & & & & & \\
\hline & & & & & & \\
\hline
\end{tabular}

*Alimentos comprados, despesas veterinários

b) Autoconsumo familiar de produtos animais

\begin{tabular}{|l|l|l|}
\hline Natureza dos Produtos & Quantidades Consumidas/ano & Valor Estimado \\
\hline & \multicolumn{3}{|c|}{} & \\
& & \\
& & \\
\end{tabular}




\section{C - Síntese}

1. Caracterizar o estabelecimento por: sua dimensão, as principais orientações do sistema de produção, considerando a valorização das produções.

2. Situar as atuais produções em relação ao passado recento e as orientações para o futuro próximo (3 anos).

3. A partir do inventário das produções e dos níveis de produção, avaliar e classificar a importância relativa das diferentes produções em relação a SAU, a ST, a T.C., aos redimentos fisicos, as margens brutas e o nível de emprego de insumos tendo como referência as normas de produção regionais.

4. Hierarquizar a partir de diferentes parâmetros as diferentes produções.

5. Estimar o produto bruto do estabelecimento e o produto bruto por hectare, utilizando referências de preços médios regionais; situar os resultados do estabelecimento: rendimentos, custos, produtos brutos, em relação as variações regionais.

1.

2.

3. 


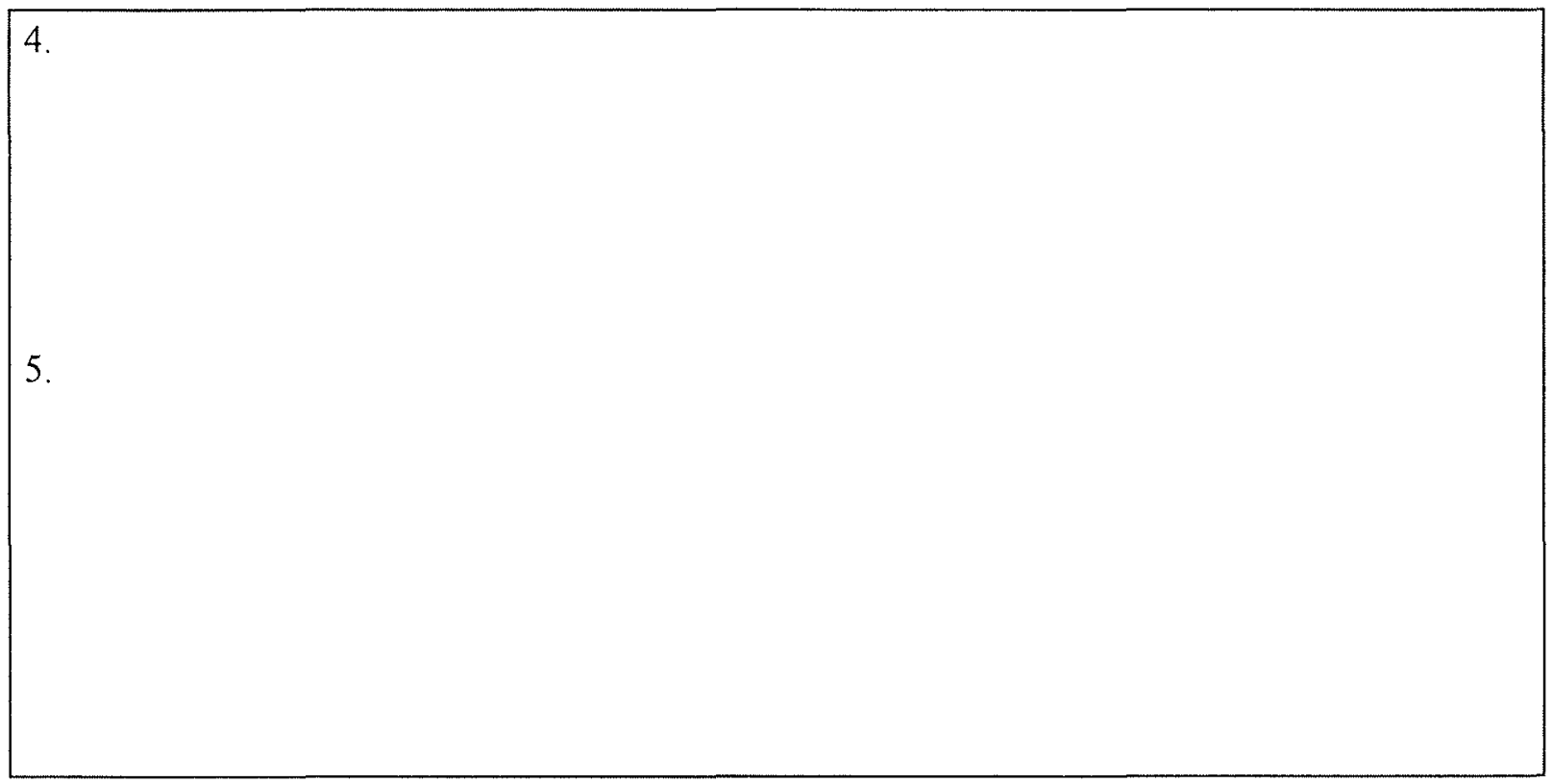


IV - A FAMÍLIA E SEUS OBJETIVOS

A - Composição da família, tipo e quantidade de trabalho

\begin{tabular}{|l|l|l|l|}
\hline Membro da Família* & $\begin{array}{l}\text { Idade } \\
* *\end{array}$ & Atividade no Estabelecimento & Trabalho fora do Estabelecimento \\
\hline & & & \\
& & & \\
& & & \\
\hline
\end{tabular}

* Grau de parentesco com o chefe do estabelecimento

** Para as crianças, anotar o tipo de estudos realizados

\section{B - Sucessão}

Existência de um sucessor: ( ) Sim ( ) Incerto ( ) Não

Quem? Em que situação

C - As exigências da família quanto:

- A renda

- A qualidade de vida

- O trabalho

- A constituição do patrimônio

- Outros aspectos: moradia... 
- O estabelecimento agrícola (trabalho e renda correspondentes) é capaz de satisfazer as exigências da família? Se não, que outras atividades?

- Posição dos diferentes membros da família em relação a situação atual concernente aos aspectos acima.

- Quem toma as decisões?

\section{D - Síntese}

1. Os objetivos da família em relação ao estabelecimento

2. Em que as produções atuais (combinação e nível) correspondem aos objetivos declarados pela família?

3. A ausência ou a presença de uma ou várias atividades produtivas pode ser justificada pelo gosto ou pela formação dos membros da família?

1.

2.

3. 
V - APARELHO DE PRODUÇÃO

\section{A - As terras}

1. Descrição e identificação das glebas

- Data da última incorporação ou desmembramento do estabelecimento:

- Número de glebas:

- Localização geográfica (dispersão, distância da sede):

- Inventário dos tipos de terrenos segundo o agricultor: as principais características, sua importância relativa no estabelecimento e sua utilização agrícola.

Detectar: as localizações privilegiadas e os locais impróprios:

as restrições e trunfos em relação a utilização agrícola (escolha das espécies, variedades, de sucessões ou de níveis de intensificação), natureza, extensão ou superficie.

Completar a tabela da página seguinte 


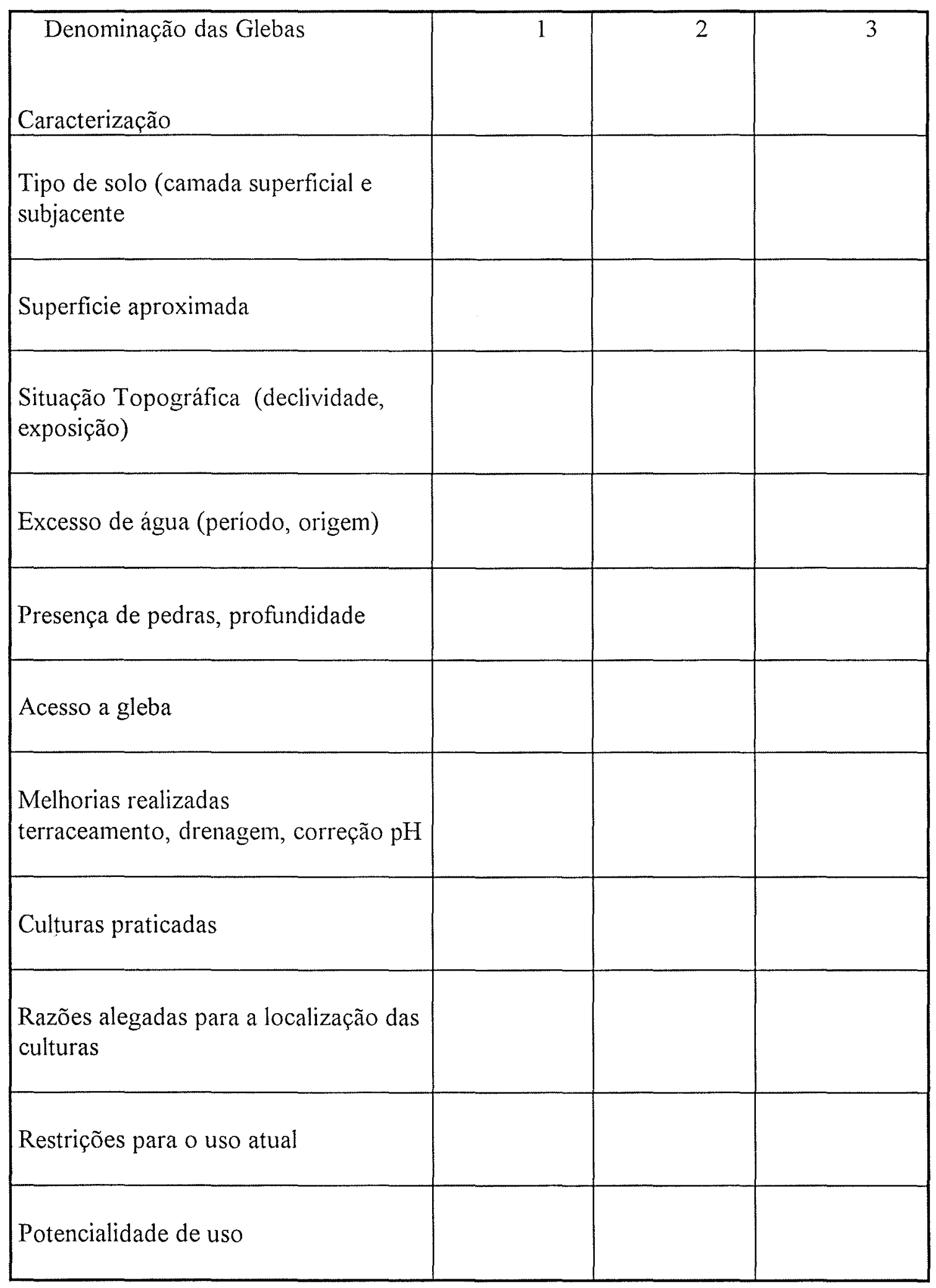


2. Glebas e Sucessão de Culturas

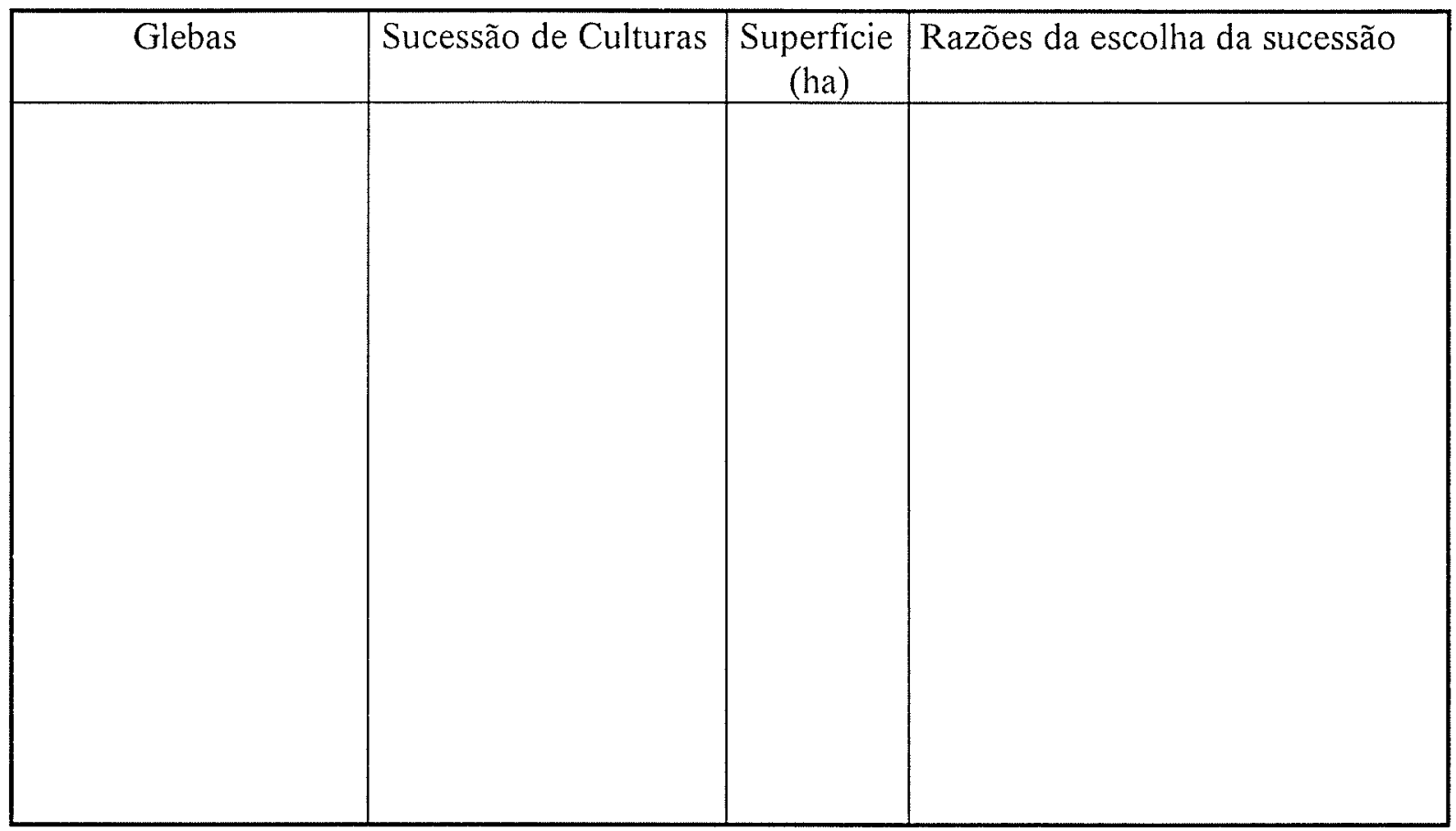

3. As melhorias do meio natural realizadas

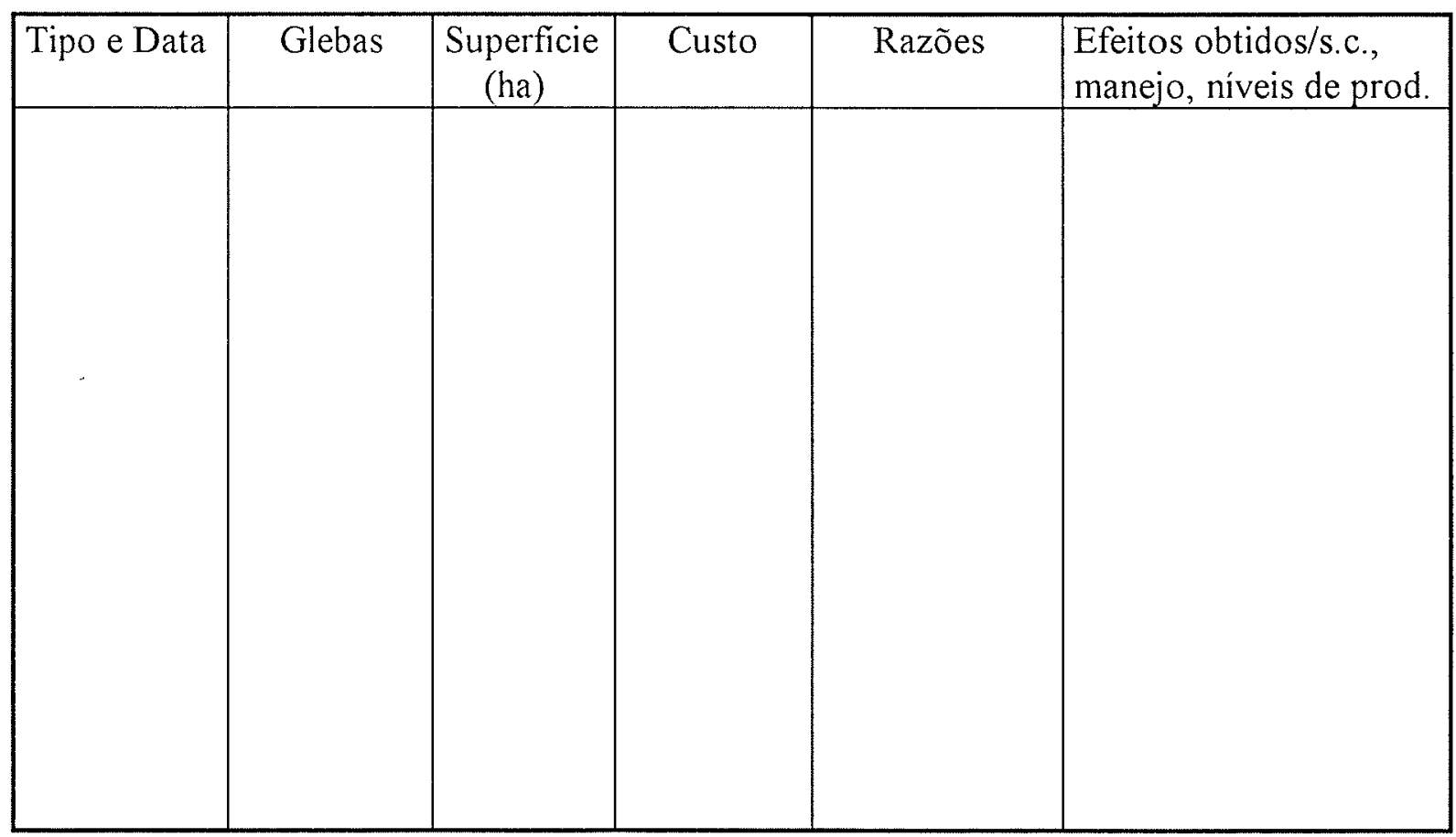


4. Datas e modalidades de financiamento das melhorias realizadas?

\section{5 - Síntese}

Relações entre as características das glebas e as decisões quanto a repartição das culturas.

1. Em que as atuais práticas levam em conta as características das glebas (em interação com o devir, localização, exclusão, limitação da importância de uma cultura ou especulação ou condução).

2. As intervenções sobre o meio fisico (melhorias), as razões que levaram o agricultor a fazêlos, as evoluções induzidas.

3. Restrições e potencialidades das áreas (solos, topografia, glebas) e o modo de valorizá-los em relação a utilização agrícola (escolha das espécies e do manejo).

4. Em relação a localização, ou do ponto de vista da natureza das terras, pode-se falar de atividades privilegiadas? Quais?

1. 


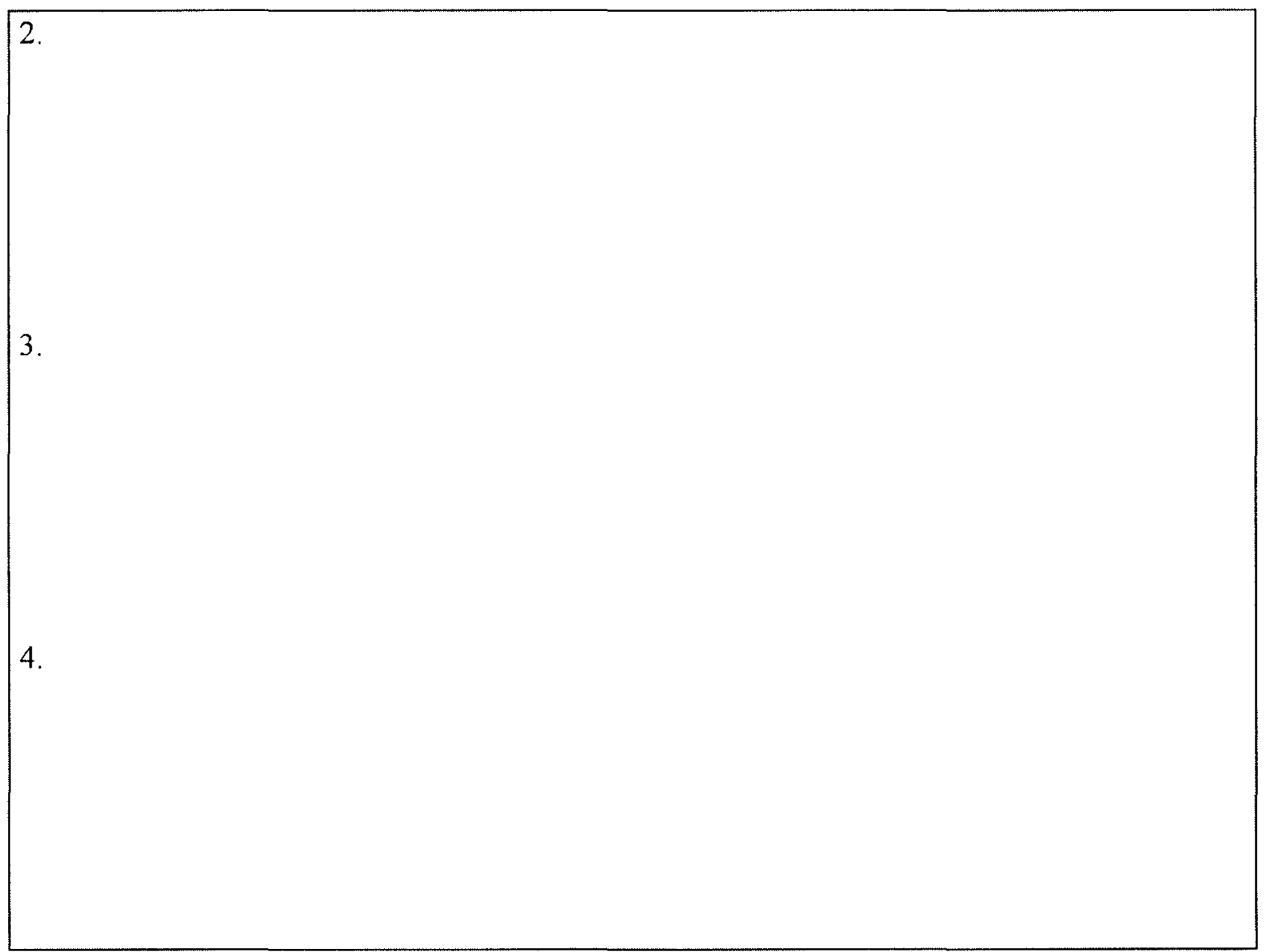




\section{B - A mão-de-obra}

1. Atividades do pessoal do estabelecimento

\begin{tabular}{|l|l|l|l|}
\cline { 2 - 4 } \multicolumn{1}{c|}{} & Pessoa * & $\begin{array}{l}\% \text { do tempo dedicado ao } \\
\text { estabelecimento }\end{array}$ & $\begin{array}{l}\text { Atividades que realiza a Nível de } \\
\text { formação }\end{array}$ \\
\hline F & & & \\
A & & & \\
M. & & & \\
\hline A & & & \\
S & & & \\
S. & & & \\
\hline
\end{tabular}

* Denominação tendo em vista o grau de parentesco com o chefe de família.

Existem atividades ou produções associadas a uma pessoa em particular?

Há outras atividades que não agrícolas?

Pessoas envolvidas?

Férias: Duração e datas? 
2. Recurso a cooperação e/ou serviços de terceiros.

Para quais trabalhos, por razões de mão-de-obra disponível ou de equipamentos?

\begin{tabular}{|l|l|l|}
\hline Trabalhos & Cooperaç̃o & Serviço de Terceiros \\
\hline & & \\
& & \\
& & \\
& & \\
& & \\
\hline
\end{tabular}

3. Adequação da oferta-demanda de mão-de-obra

- O agricultor considera que a mão-de-obra que dispõe é suficiente ou há excesso?

- Existem períodos nos quais há inadequação entre oferta e demanda? Se sim, quais?

- Qual é a ação face a isto que ele toma?

- A mão-de-obra disponivel pode justificar a presença de certas produções e/ou certos modos de condução?

- Certas produções (quais?) justificam a presença de mão-de-obra (em particular assalariados?)? 


\section{Síntese}

4.1. Caracterizar as escolhas feitas em matérias de empregos de mão-de-obra.

4.2. Há atividades privilegiadas quanto a alocação de mão-de-obra?

4.3. Qual(is) a(s) incidência(s) da mão-de-obra sobre as escolhas das produções, sua extensão e sua condução (restrições e potencialidades)?

4.1 .

4.2.

4.3: 


\section{C - Máquinas, Equipamentos e Instalações}

1. Inventário das máquinas e equipamentos e de suas características

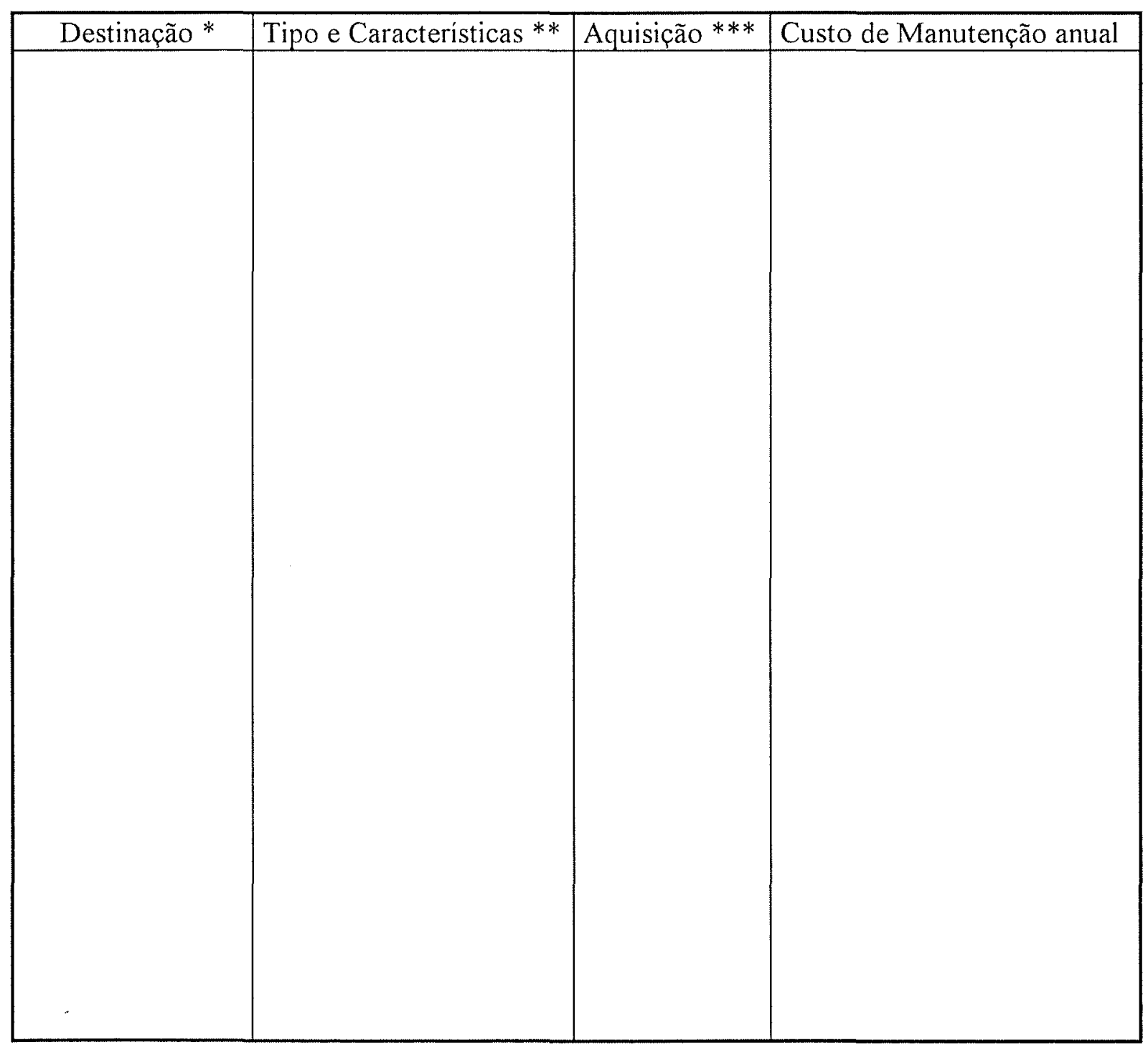

* Finalidades de uso: tração, preparo do solo, etc.

** Modelo, ano de fabricação, potência, largura de trabalho, etc.

*** Data aproximada e modo de aquisição e tipo de propriedade. 
2. Instalações

\begin{tabular}{|l|l|c|c|}
\hline Destinação & $\begin{array}{l}\text { Tipo e Características } \\
\text { Data de construção }\end{array}$ & $\begin{array}{c}\text { Vantagens e } \\
\text { Inconvenientes* }\end{array}$ & $\begin{array}{c}\text { Custo de Manut. } \\
\text { Anual }\end{array}$ \\
\hline & & & \\
& & & \\
& & & \\
& & & \\
\hline
\end{tabular}

* Segundo o agricultor e notadamente em relação ao estado sanitário da criação, a comodidade do manejo alimentar e dos dejetos

3. Avaliar o grau de autonomia do estabelecimento quanto aos equipamentos:

- Confrontar o material existente com o equipamento necessário tendo visto os cultivos e as criações:

- Apontar as operações de manutenção e de reparação executadas na propriedade.

- Avaliar o estado do(s) trator(es) e do(s) principal(is) material(is) de colheita: 
4. Avaliar as performances dos materiais e equipamentos em relação à:

- Carga de trabalho

- Aos resultados técnicos (qualidade)

5. Modalidades de financiamento dos materiais, equipamentos e instalações:

Empréstimos realizados: data, objeto, montante, taxa; organismo financiados

Observações complementares:

6. Síintese

6.1. Caracterizar as escolhas feitas em matéria de máquinas e equipamentos.

6.2. Há produções privilegiadas nas decisões referentes as máquinas e agrupamentos? 
6.3. Potencialidades e restrições: em que os equipamentos e o material limitam, ou favorecem, certas atividades produtivas e/ou seus manejos?

6.4. A presença de um equipamento impõem alguma produção?

6.1.

6.2.

6.3 .

6.4 


\section{D - Contexto Sócio-Econômico}

1. Inventário das relações do estabelecimento com o exterior e razões das escolhas feitas Os fornecedores do estabelecimento

\begin{tabular}{|l|l|l|}
\hline $\begin{array}{l}\text { Natureza e destinação dos } \\
\text { produtos comprados }\end{array}$ & $\begin{array}{l}\text { Fornecedores (identificação, } \\
\text { natureza jurídica das relações) }\end{array}$ & $\begin{array}{l}\text { Razões da escolha } \\
\text { Restrições ou vantagens } \\
\text { particulares }\end{array}$ \\
\hline & & \\
& & \\
& & \\
& & \\
\end{tabular}

Os compradores dos produtos do estabelecimento

\begin{tabular}{|l|l|l|}
\hline $\begin{array}{l}\text { Natureza dos produtos } \\
\text { vendidos }\end{array}$ & $\begin{array}{l}\text { Comprador (identificação } \\
\text { natureza jurídica das relações) }\end{array}$ & $\begin{array}{l}\text { Razões da escolha } \\
\text { Restrições ou vantagens } \\
\text { particulares }\end{array}$ \\
\hline & & \\
& & \\
& & \\
& & \\
\end{tabular}


Os Serviços

\begin{tabular}{|l|l|l|}
\hline \multicolumn{1}{|c|}{ Natureza } & Parceiro & $\begin{array}{l}\text { Razões da escolha, vantagem } \\
\text { e inconvenientes }\end{array}$ \\
\hline Crédito & & \\
Informação Técnico-Econômicas & & \\
Trabalho & & \\
\hline
\end{tabular}

Atividades exercidas pelo agricultor ou outros membros da família em organismos de produção, associativos, religiosos, $\ldots$

\section{Sintese}

Potencialidades, restrições para o estabelecimento: em que os parceiros enumerados em suas relações com o estabelecimento impedem, favorecem, limitam as produções ou seu modo de conduzir (preços, quotas, contratos, restrições, industriais ... acesso ao crédito) 


\section{E - Síntese Geral do aparelho de produção}

Para as produções do estabelecimento, ou para outras produções presentes na região e seu modo de condução, recapitular e hierarquizar os fatores e/ou as condições que:

- favorecem ou impedem sua presença

- autorizam ou limitam sua extensão

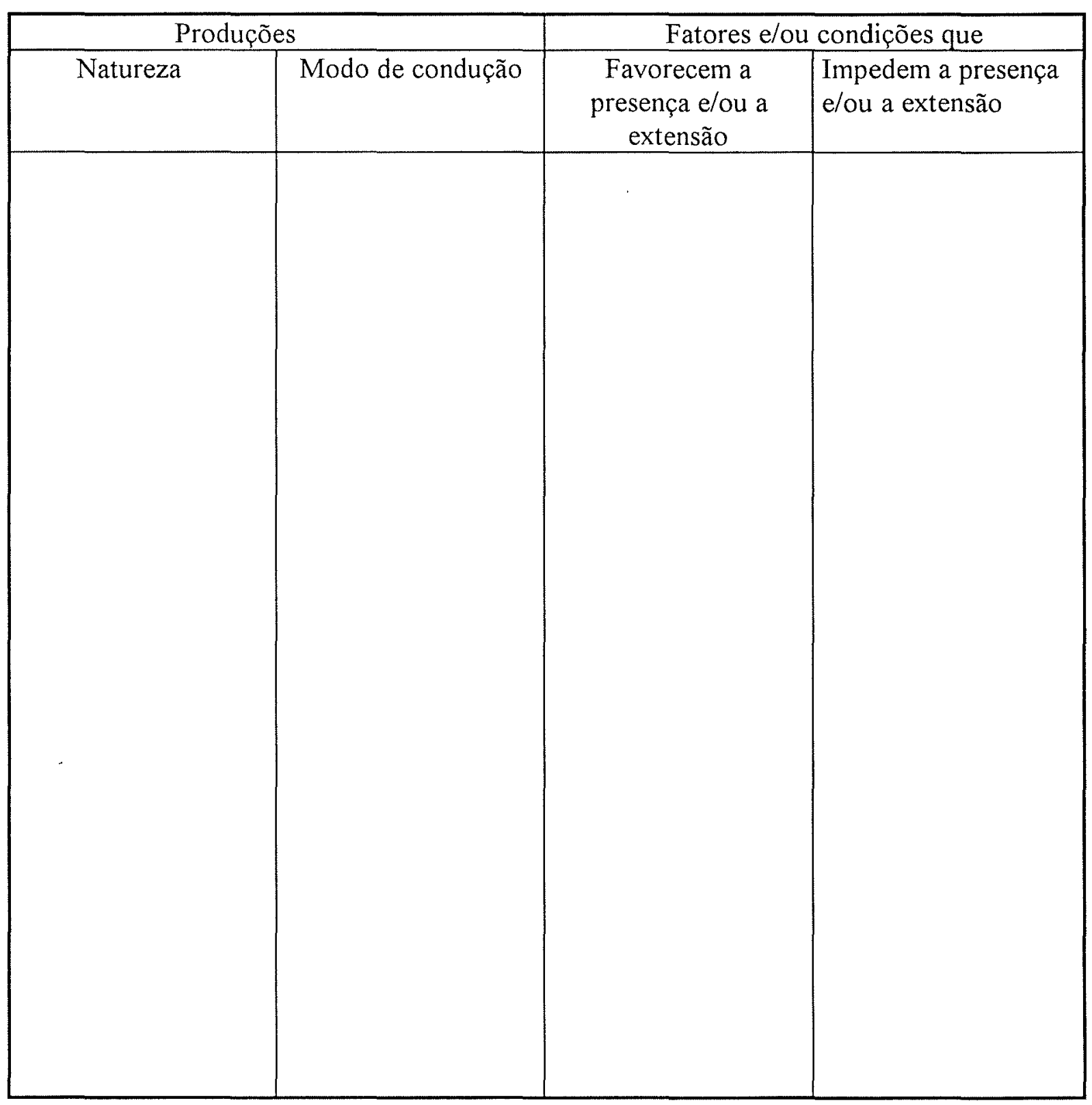




\section{VI - HISTÓRIA DO ESTABELECIMENTO}

\section{A - As modificações}

1. Caracterização rápida da situação

\begin{tabular}{|l|l|l|}
\cline { 2 - 3 } \multicolumn{1}{c|}{} & $\begin{array}{l}\text { Situação Inicial } \\
\text { Data: }\end{array}$ & $\begin{array}{l}\text { Situação a 20 anos se a data de } \\
\text { instalação é recente }\end{array}$ \\
\hline Composição da Familia & & \\
\hline \multicolumn{1}{|c|}{ SAU } & & \\
\hline Superficie & & \\
\hline $\begin{array}{l}\text { Principais Produções } \\
\text { Fam., Assal. }\end{array}$ & & \\
\hline $\begin{array}{l}\text { Principais Equipamentos e } \\
\text { Materiais }\end{array}$ & & \\
\hline
\end{tabular}

- A quem o agricultor sucedeu?

- Quais foram as condições para tornar-se proprietário ou explorador da área?

- Quais foram as condições para receber o material aparelho de produção?

- O agricultor vem de outra região? De onde? 
2. Evolução das atividades de produção animal

Existem períodos, desde que o agricultor assumiu o estabelecimento em que aumentou ou iniciou determinado tipo de produção 10animal? Que espécie, quando e por quê? Quando parou com a produção se resolveu aumentá-la e por quê?

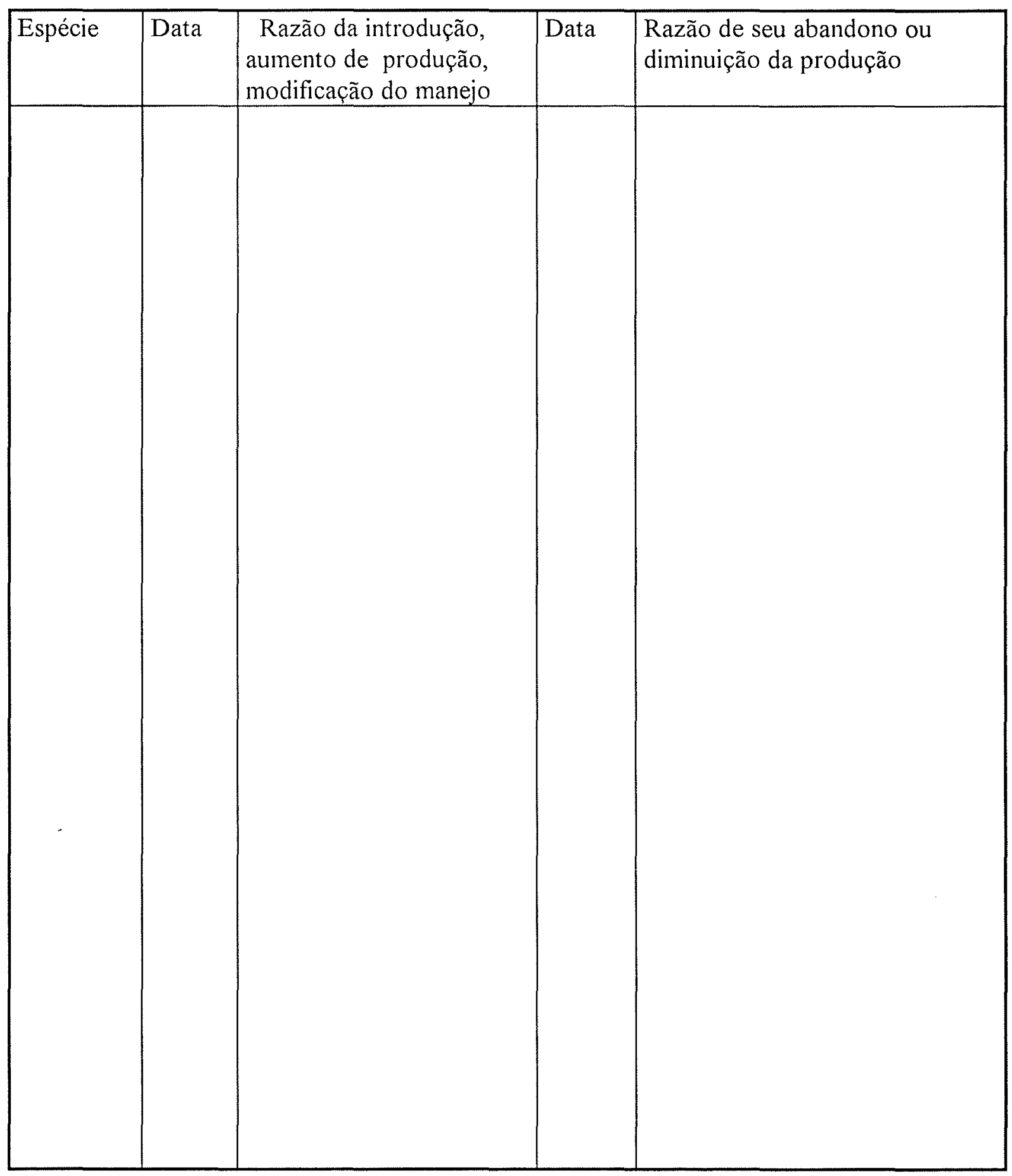


3. Evolução das atividades de produção vegetal

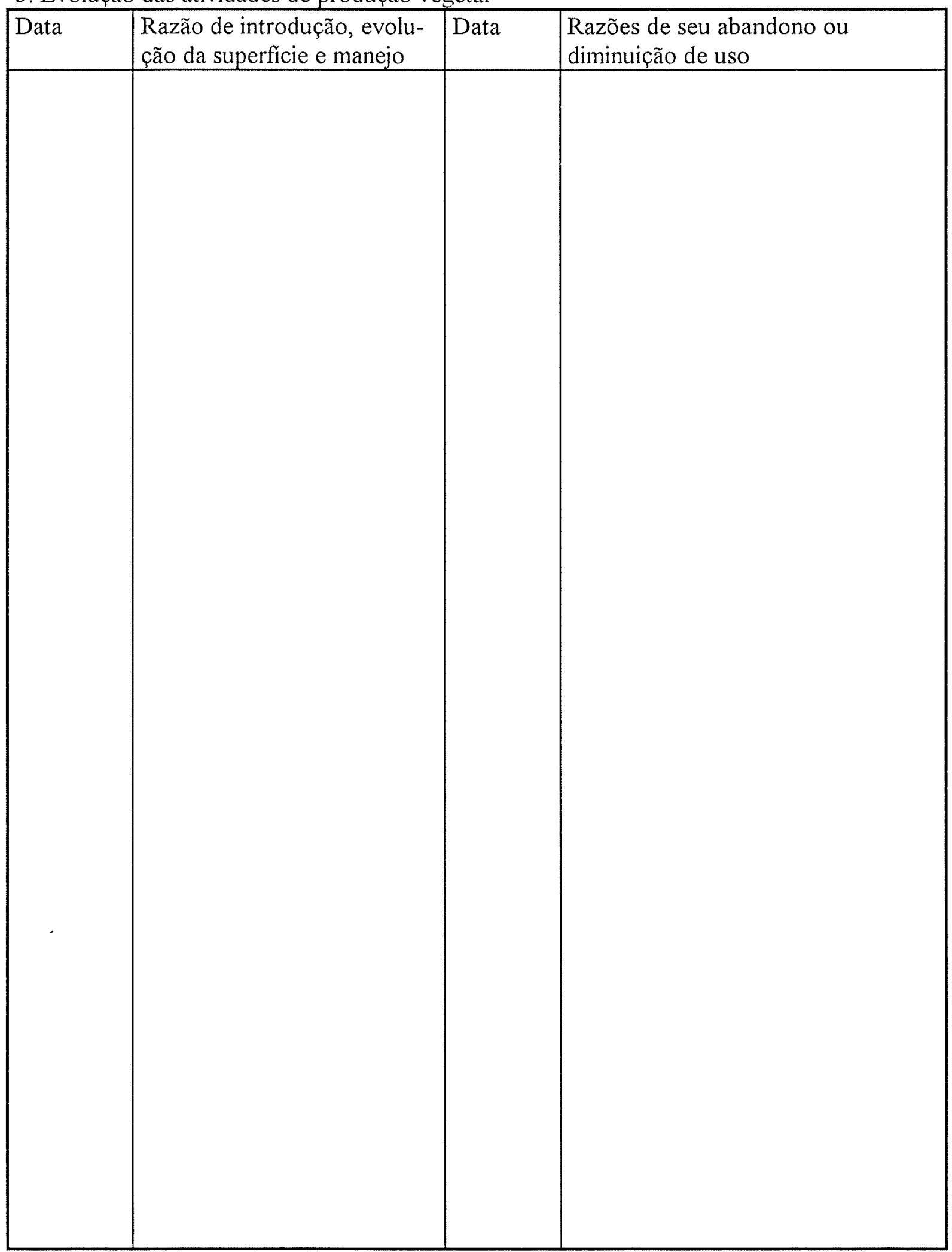


4. Evolução das máquinas, equipamentos, instalações e melhorias do meio

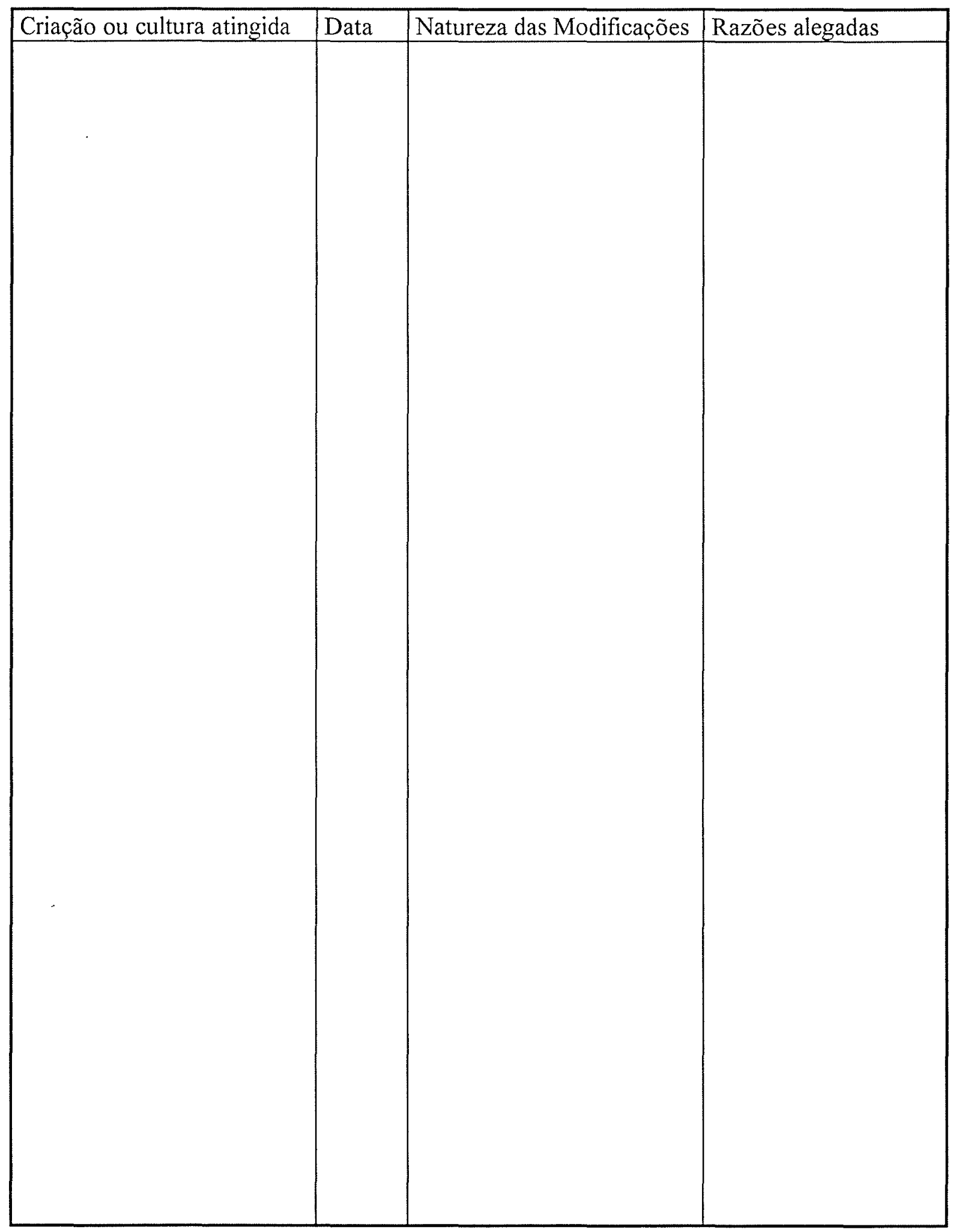


5. Adaptações do estabelecimento as modificações do contexto (oportunidades de melhorias coletivas, oferta de subsídios, abertura ou fechamento de um mercado, variações de preços...)

\section{B - Síntese}

Tomando uma escala de tempo idêntica:

1. Identificar as datas e principais mudanças do sistema de produção a partir das tabelas precedentes. Indicar as razões alegadas para estas mudanças, em particular as ligações com a evolução da família.

2. Apreender e datar as diferentes fases do ciclo familiar.

3. A partir destes elementos de sintese, definir as diferentes etapas percorridas pelo estabelecimento e as modalidades de passagem de uma etapa a seguinte.

\section{Datas}

Fases do Ciclo Familiar

As etapas identificadas

As modalidades de passagem 
4. Ao longo da evolução passada, o agricultor e/ou sua família visaram a constituição de patrimônio, a melhoria das instalações e equipamentos, a reprodução da mão-de-obra...?

5. Situar o estado atual do estabelecimento em relação a última etapa da história.

6. Estabelecer as ligações entre as produções atuais e/ou as características do estabelecimento (SAU, mão-de-obra, equipamento, mercado...) e a história. 
VII - AS ESCOLHAS ESTRATÉGICAS E SEUS DETERMINANTES

A - A família face aos resultados econômicos do estabelecimento

* A renda obtida no estabelecimento, limita as despesas privadas?

Limita certos investimentos? Quais?

- Há necessiddae de uma renda exterior ao estabelecimento agrícola?

- Os custos são muito elevados?

- Custos operacionais: qual(is) rubrica(s)?

- Custos fixos: qual(is) rubrica(s)?

* O produto bruto parece ser muito baixo?

- Qual(is) rubrica(s)?

- Os resultados técnicos de certas atividades são responsáveis? Quais e porque?

* A capacidade financeira do estabelecimento tem algum problema? 
- A curto prazo (caixa)?

* Quando?

* Por que?

* Como enfrentá-la?

* Desde quando há estes problemas?

- A médio e a longo prazo: Quais empréstimos, para quais investimentos (os principais)? Quais os problemas?

- A capacidade de empréstimo do estabelecimento e as diversas fontes financiadoras possíveis estão esgotadas?

- A partir de que soma de dinheiro o agricultor decide recorrer a um empréstimo? 


\section{B - Os projetos}

Precisar os projetos, indicando igualmente os meios que o agricultor conta para realizá-los e a que prazo.

\begin{tabular}{|c|c|c|c|}
\hline $\begin{array}{l}\text { Resultado buscado: } \\
\text { "Melhorar" }\end{array}$ & $\begin{array}{l}\text { Modificações } \\
\text { previstas }\end{array}$ & para * & \\
\hline & As produções vegetais & $\begin{array}{l}\text { As produções } \\
\text { animais } \\
\end{array}$ & $\begin{array}{l}\text { A gestão do } \\
\text { estabelecimento** }\end{array}$ \\
\hline $\begin{array}{l}\text { 1 - A Renda } \\
\text { a) aumentando o } \\
\text { Produto Bruto }\end{array}$ & & & \\
\hline $\begin{array}{l}\text { b) Reduzindo os } \\
\text { custos } \\
\text { operacionais }\end{array}$ & & & \\
\hline $\begin{array}{l}\text { c) Reduzindo os } \\
\text { custos fixos }\end{array}$ & & & \\
\hline 2. O trabalho & & & \\
\hline 3. Outros & & & \\
\hline
\end{tabular}

* Considerar as modificações de SAU e de uma repartição entre as atividades e as modificações de condução de uma ou de várias atividades produtivas.

** Investimentos, financiamento, mão-de-obra, patrimônio. 


\section{C - Síntese}

1.. Anotar no Esquema da página seguinte ::

- nos quadros de traços cheios: as conclusões essenciais dos capítulos precedentes;

- nos quadros de traços pontilhados: as relações detectadas entre combinação de produç es e de outras rubricas.

- em relação ao contexto sócio-econômico, meio físico, mão-de-obra equipamentos e instalações distinguir os trunfos e as restrições. 


\section{DETERMINANTES DA COMBINAÇÃO DAS ATIVIDADES SE PRODUÇÃO}

(principais potencialidades e restrições que orientam a escolha das produções, sua extensão e suas conduções)

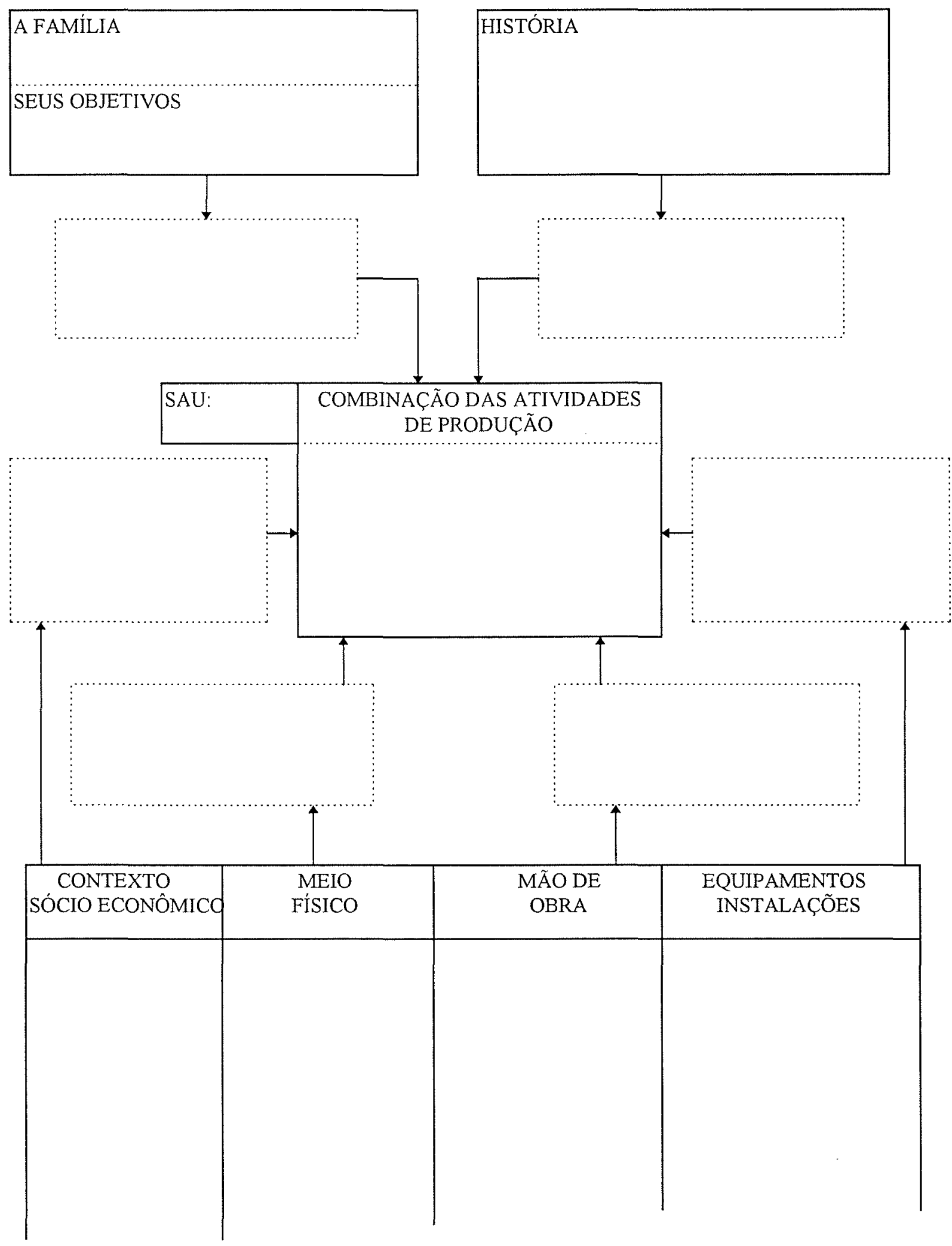


2. Recapitular as decisões importantes que sofre o estabelecimento no momento da enquete, e evidenciar nas relações com os objetivos gerais da família.

\begin{tabular}{|l|l|l|}
\hline Rubricas & Decisões ou Escolha do agricultor & Objetivos correspondentes \\
\hline $\begin{array}{l}\text { Dimensões do } \\
\text { estabelecimento }\end{array}$ & & \\
\hline $\begin{array}{l}\text { Combinação de } \\
\text { Produção }\end{array}$ & & \\
\hline Melhoria do meio & & \\
\hline $\begin{array}{l}\text { Mão-de-obra e } \\
\text { Trabalho }\end{array}$ & & \\
\hline $\begin{array}{l}\text { Máquinas, } \\
\text { Equipamentos, } \\
\text { Instalações }\end{array}$ & & \\
\hline $\begin{array}{l}\text { Gestão do } \\
\text { Estabelecimento }\end{array}$ & & \\
\hline $\begin{array}{l}\text { Relações com o } \\
\text { sócio-econômico }\end{array}$ & & \\
\hline
\end{tabular}


3. Esquema de funcionamento

- Inicia-se por formular a estratégia (o conjunto de escolhas):

. que explicam as produções, sua condução, o aparelho produtivo;

- que correspondem aos objetivos gerais levantados e para os quais pode-se observar as decisões passadas concernentes ao estabelecimento ou de projetos de melhoria.

É entorno da Estratégia - objetivos gerais que será organizado o esquema de funcionamento:

1. Completa-se os três quadros "Estratégia", "Situação familiar e objetivos" e "Dimensão do estabelecimento".

2. A partir dos dados das páginas 129 e 130 , caracteriza-se o estabelecimento e as relações com contexto sócio-econômico, não modificáveis atualmente pelo agricultor e sua família, e que influem sobre as decisões estratégicas em um sentidof avorável aos objetivos (trunfos) ou desfavoráveis (restrições);

3. Caracteriza-se grosseiramente os resultados técnicos e econômicos (em particular com a ajuda dos dados do terceiro e sétimo capítulos) e se restabelece ligações ao ponto de vista e eventualmente aos projetos de melhoria do agricultor e de sua família. Se não for possivel integrar ao esquema uma produção e/ou um elemento do estabelecimento, considerado importante, é necessário retomar as diferentes sínteses para reformular, de uma maneira mais adequada, a estratégia e/ou os objetivos: "não separa sem que se tenha evidenciado a coerência das escolhas", em certos casos, será necessário retornar a casa do agricultor para obter complementações à informações ou para verificar as bases das hipóteses que foram formuladas ao longo das diversas sínteses. 
ESQUEMA DE FUNCIONAMENTO

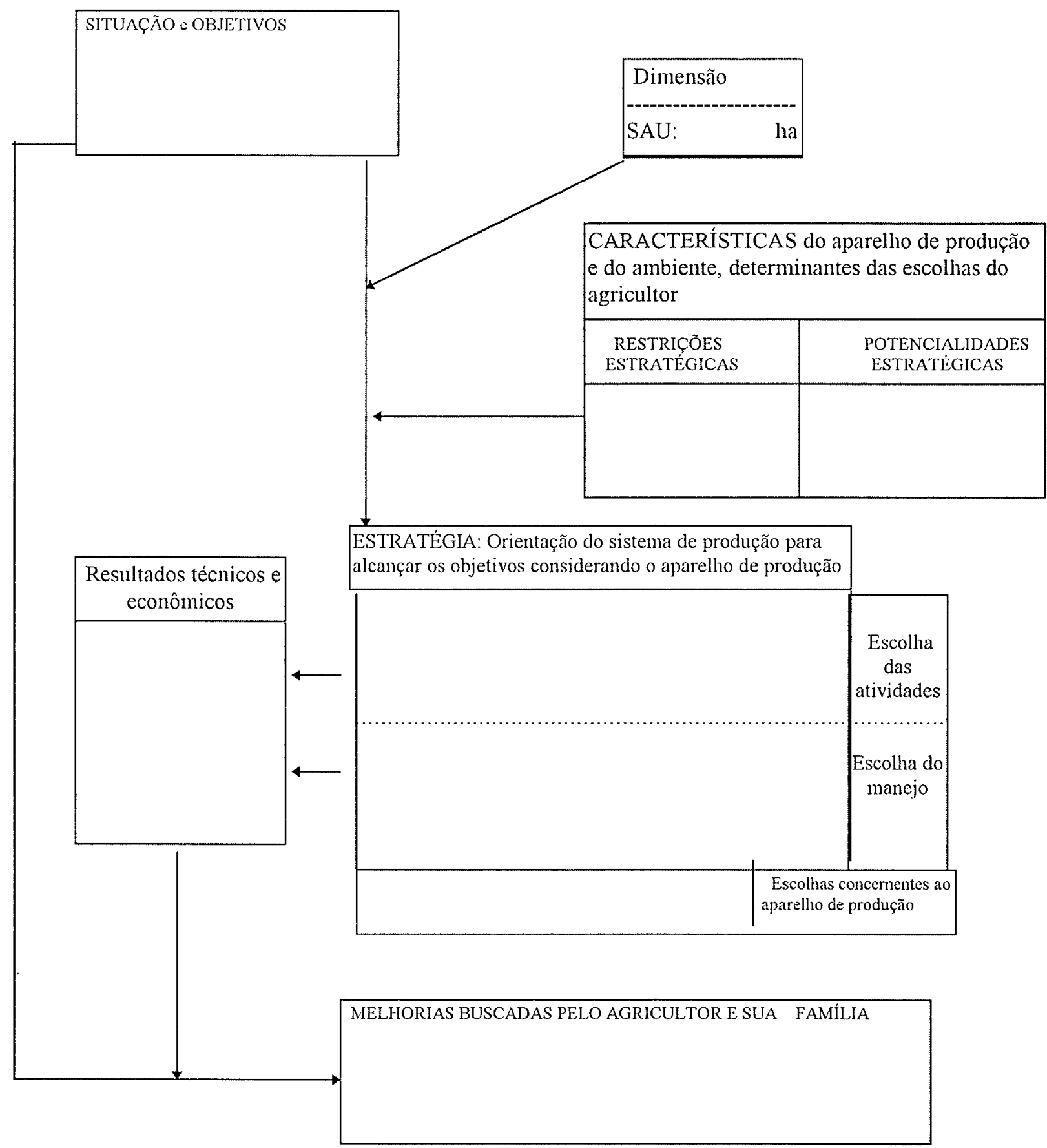


SEGUNDA PARTE : funcionamento técnico e elaboração de Diagnósticos Setoriais 
I - O MANEJO DOS ANIMAIS E DOS SISTEMAS DE CRIAÇÃO

Rubricas a abordar:

- As produções (quantidade e repartição ao longo do ano, qualidade), modos de condução e alimentação dos animais, problemas sanitários.

DIAGNÓSTICO

1. Os resultados da atividade (quantidade, qualidade) estão de acordo aos objetivos?

2. Em que os elementos de manejo, abaixo relacionados, interferem na produção?

- Controle de alimentação:

* Relações entre alimentação e produções animais? 
- Como é feita a adequação entre oferta e demanda em forragem? Repercussões sobre a repartição da superficie cultivada?

- Parte da alimentação obtida fora do estabelecimento?

- Quais são as soluções de segurança quando há falta de forrageamento?

* Venda de animais?

* Compra de alimentos, de forragem?

* Política de armazenamento de forragens?

* Modificações de manejo dos animais? Dos efetivos?

* As instalações dos animais:

* A sanidade dos animais:

* Referencial técnico do agricultor:

3. Melhorias projetadas

Fatores favoráveis e restrições a melhoria ou o aumento das atividades de produção animal. Relação com outros setores da produção do estabelecimento. 
II - O MANEJO DAS CULTURAS E DOS SISTEMAS DE CULTIVO

Questões a abordar:

* Diversidade dos manejos por cultura, segundo o precedente e o terreno (reconstruir os itinerários técnicos).

* A partir da tabela da página, definição dos sistemas de cultivo presentes e de sua localização no terreno.

* Balanços nutricionais para cada caso (sistema de cultivo x terreno).

* Rendimento das principais culturas, variações entre anos e entre terrenos, razões alegadas pelo agricultor para explicar estar variações.

DIAGNÓSTICO

1. Confrontação dos níveis de rendimento e nível dos insumos. Os objetivos são alcançados?

Causas das diferenças detectadas?

2. Em relação a escolha da condução das culturas:

- grau em que considera: 
* as características do meio (clima, solo)

* precedentes culturais

* outros fatores

- conseqüências do referencial técnico do agricultor

3. Efeitos sobre a evolução do estado do meio componentes:

- físicos (efeitos a curto prazo e efeitos acumulativos, no qual papel da matéria orgânica)

- químicos

- estado sanitário

4. Melhorias projetadas: fatores favoráveis e restrições a um aumento de rendimentos?

(Quantidade produzida por hectare ou produção por quantidade de um fator). Consequêencias para outros setores de produção?

5. Temas identificadas que exigem um estudo mais aprofundado. 
III - ORGANIZAÇÃO DO TRABALHO

Rubricas a abordar:

- Atividades de Produção Animal (avaliação dos tempos necessários as operações cotidianas e periódicas para as operações de transformação e de comercialização).

- Produções Vegetais (calendário de trabalho, organização das principais atividades).

- Identificação dos piques de trabalho e dos períodos de pouco trabalho.

DIAGNÓSTICO

1. O emprego da mão-de-obra no estabelecimento

2. Os pontos de bloqueio para a realização dos trabalhos?

* Equipamento

* Mão-de-obra

* Organização do trabalho

3. As melhorias desejáveis. 
IV - RENDA E FINANCIAMENTO

Rubricas a abordar:

* Estrutura da renda da safra (atividades de produção animal e vegetal, rendas exteriores); abordagem do fluxo de caixa.

* Financiamento (empréstimos para instalações, fundiários, material, capital, empréstimos a curto prazo, subvenções e auxílios diversos...)

DIAGNÓSTICO

\section{O Produto Bruto}

Distinguir PB da atividade vegetal e PB atividade animal Importância relativa das atividades. Certas contas aparecem muito baixas? Por que? Como corrigir?

2. Os custos

* Custos de produção das atividades: vegetais e animais

Importância relativa das diversas atividades 
* Custos de produção e custos fixos: Quais as contas que parecem ser muito elevadas? Por que? Como corrigir?

\section{A Renda}

Seu nível, provocou, provoca, ou poderá provocar:

* uma descapitalização? Qual?

* a necessidade de renda complementar exterior; ou um financiamento? Qual? Por quê?

4. Fluxo de Caixa

* Detectar os períodos dificeis.

* Recorre a empréstimos a curto prazo? Quando?

* Quais as conseqüências para o estabelecimento?

\section{O Financiamento}

* Recorre a empréstimos a médio e a longo prazo nos últimos dez anos? Para qual(is) investimento(s)? Como faz as prestações? 
* Consequêencias para a unidade de produção e para a família?

6. Tendo em vista os problemas detectados, quais modificações de produções ou de condução não desejáveis? Quais as atividades produtivas devem ser mantidas? 
TERCEIRA PARTE : funcionamento do estabelecimento proposições de melhorias 
A - Para cada atividade de produção caracterizar:

* Os resultados obtidos: os níveis de producão ou performances, os principais meios para alcançá-los (internos e externos ao estabelecimento) e os problemas, ou seja, as dificuldades evidenciadas ao longo dos diagnósticos e que devem ser resolvidos para obter os resultados em conformidade aos objetivos e capaz de manter a reprodutibilidade do par agricultor e sistema de produção

* As potencialidades e restrições detectadas em cada setor de produção (potencialidades e restrições em relação aos objetivos de produção).

\begin{tabular}{|l|l|l|l|l|l|}
\cline { 2 - 6 } \multicolumn{1}{c|}{} & $\begin{array}{l}\text { Resultados e } \\
\text { Performances }\end{array}$ & $\begin{array}{l}\text { Principais } \\
\text { Meios Usados }\end{array}$ & Problemas & Potancialidades & Restrições \\
\hline $\begin{array}{c}\text { Atividades de } \\
\text { Produção } \\
\text { Vegetal }\end{array}$ & & & & & \\
\hline $\begin{array}{c}\text { Atividades de } \\
\text { Produção } \\
\text { Animal }\end{array}$ & & & & & \\
\hline Trabalho & & & & & \\
\hline & & & & & \\
\hline Economia & & & & & \\
& & & & & \\
\hline
\end{tabular}


B - Em que a análise dos resultados e dos processos de produção permitem:

* precisar, ratificar, modificar a formulação das escolhas, potencialidades e restrições estratégicas do Capítulo VII da primeira parte do guia?

Novas formulações

C - Situar a importância de ações concernentes aos sistemas de cultivo no funcionamento da unidade de produção. 
D - Situar a importância de ações concernentes aos sistemas de criação e ao sistema forrageiro em relação ao funcionamento da unidade de produção 
E- ESQUEMA DE FUNCIONAMENTO modificado segundo os itens A e B

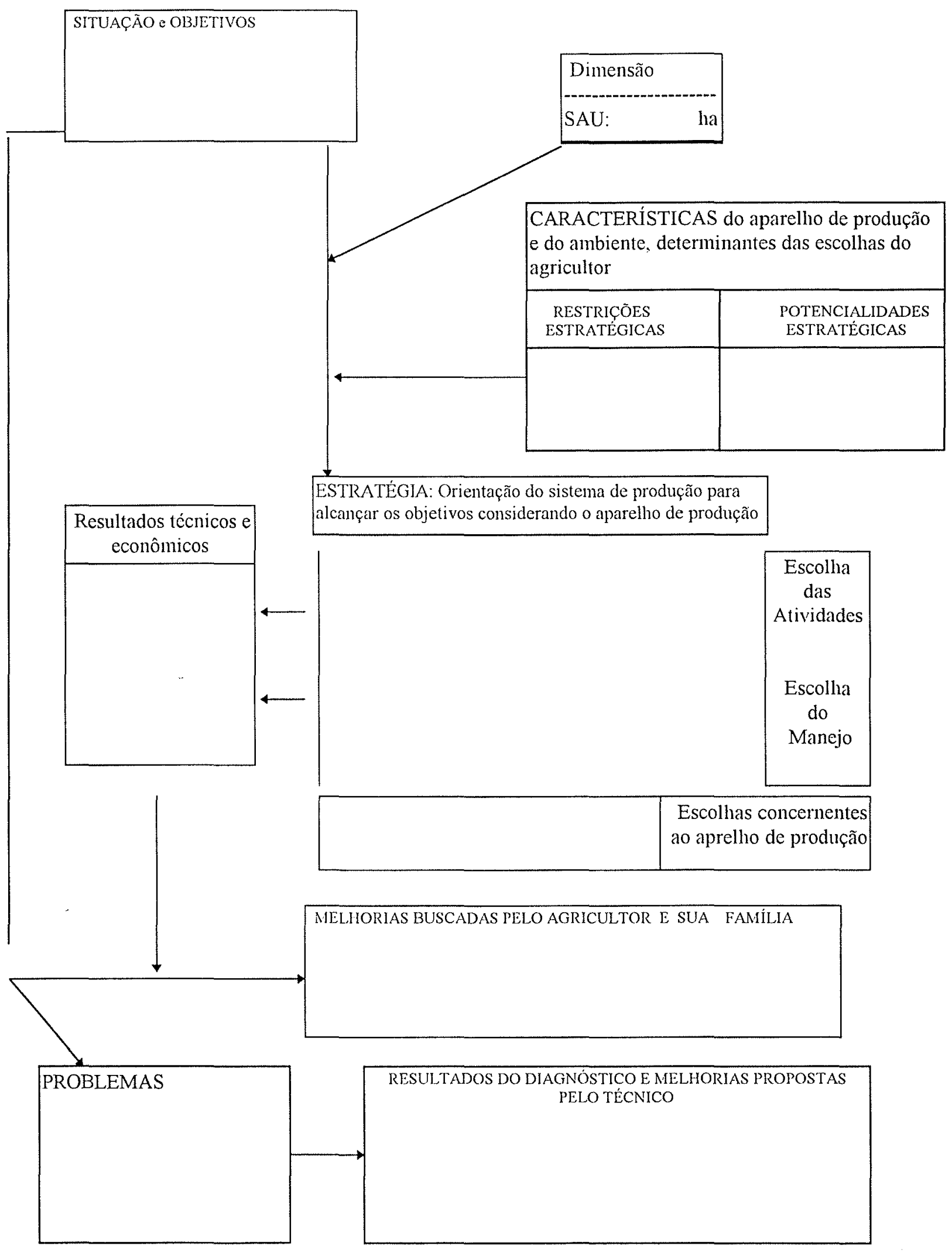




\section{FICHAS COMPLEMETARES}

Organização do Trabalho

a) Criações e transformações dos produtos

1. Avaliar o número de horas necessárias para os trabalhos diários. Diferencia-se os períodos do ano se necessário. Indicar as pessoas envolvidas por estes trabalhos.

2. Operações periódicas: indicar os tempos necessários e os períodos das operações, como, recolhimento do esterco.

3. Operações de comercialização ou transformação de produtos animais ou vegetais.

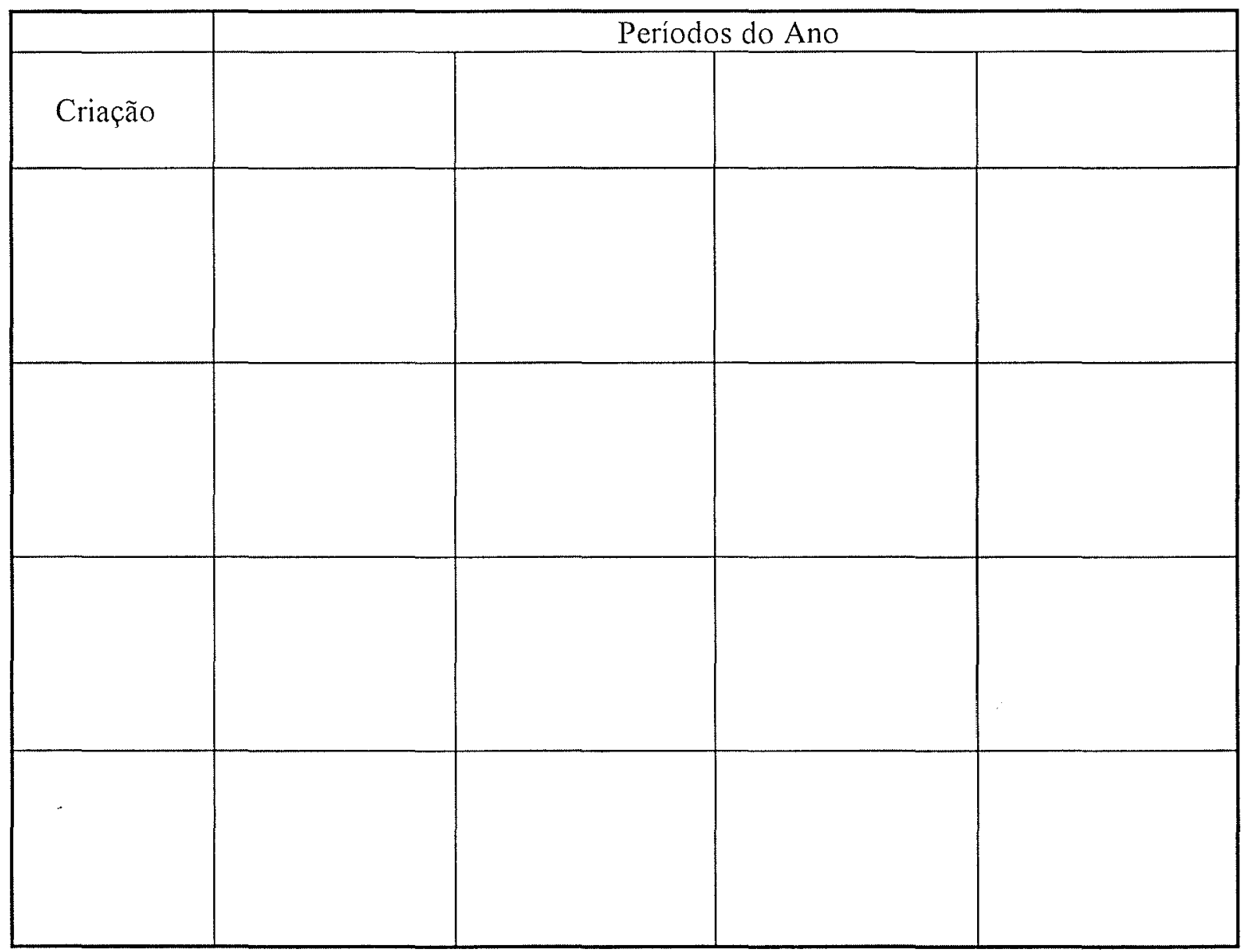

b) Culturas

1. Calendário cultural

* Para cada cultura, diferenciando o precedente e o terreno, indicar a ordem de intervenção para as principais técnicas culturais da colheira da cultura anterior até a colheita da cultura atual. 
A tabela abaixo deverá permitir evidenciar as cronologias entre culturas, ou entre culturas $\mathrm{x}$ precedente

\begin{tabular}{|c|c|c|c|c|c|c|c|c|c|c|c|c|c|c|}
\hline Culturas & Precedente & Terreno & J & F & M & A & M & J & J & A & S & O & N & D \\
\hline & & & & & & & & & & & & & & \\
& & & & & & & & & & & & & & \\
\end{tabular}


2. Evidenciar os principais blocos de trabalho (períodos em que se desenvolvem várias operações importantes) e caracterizar a organização das atividades.

\begin{tabular}{|c|c|c|c|}
\hline Período & Inventário das Operações & $\begin{array}{l}\text { Cronologia das Operações } \\
\text { e distribuição espacial* }\end{array}$ & $\begin{array}{l}\text { Mão-de-obra e material } \\
\text { utilizado }\end{array}$ \\
\hline & & & \\
\hline & & & \\
\hline & & & \\
\hline & & & \\
\hline & & & \\
\hline & & & \\
\hline & & & \\
\hline & & & \\
\hline & & & \\
\hline & & & \\
\hline & & & \\
\hline & & & \\
\hline & & & \\
\hline & & & \\
\hline & & & \\
\hline & & & \\
\hline & & & \\
\hline
\end{tabular}

* Indicar nesta coluna o desenrolar da atividade caracterizando a sua organização;

Razões alegadas para a escolha da organização adotada e a ordem seguida (natureza dos terrenos, material e mão-de-obra disponíveis, duração variável das diferentes operações)... 
3. Os piques de trabalho*

\begin{tabular}{|l|l|l|l|l|}
\hline $\begin{array}{l}\text { Os periodos de pique } \\
\text { (datas) }\end{array}$ & & & & \\
\hline $\begin{array}{l}\text { As culturas e a natureza } \\
\text { das diversas operações }\end{array}$ & & & & \\
\hline $\begin{array}{l}\text { As pessoas que as } \\
\text { realizam }\end{array}$ & & & & \\
\hline $\begin{array}{l}\text { Como o agricultor } \\
\text { enfrenta os piques }\end{array}$ & & & & \\
\hline $\begin{array}{l}\text { Quais são as prioridades } \\
\text { No que interfere na } \\
\text { dandução das culturação }\end{array}$ & & & & \\
\hline
\end{tabular}

* Distingue-se os períodos de pique de trabalho ligado ao:

* número de dias superior a oferta em mão-de-obra

* número de dias necessários superior ao número de dias disponíveis

4. Os períodos de sub-emprego:

O número de dias necessários a execução do trabalho é inferior a oferta de mão-de-obra e ao número de dias disponiveis.

Origem do sub-emprego? Como este "tempo livre" é utilizado? 


\section{CONCLUSÕES}

O procedimento metodológico proposto ao associar um modelo de estudo do funcionamento do par empreendedor/sistema de produção a uma modelização da diversidade de maneiras de produzir e de evolução dos sistemas de produção de uma região, permite :

- diagnosticar os pontos fortes e fracos dos sistemas de produção praticados pelos agricultores e preconizar mudanças técnicas e econômicas, no âmbito da unidade de produção agrícola, capazes de serem operacionalizadas pelos agricultores;

- definir a hierarquia dos problemas técnicos e econômicos dos sistemas de produção de uma região e deste modo auxiliar na elaboração de diretrizes de ação desenvolvimentista e no estabelecimento de linhas prioritárias de pesquisa;

- representar a diversidade de unidades de produção em tipos que se comportam de uma maneira relativamente homogênea em relação a condução técnica e aos objetivos;

- recuperar a evolução histórica dos sistemas de produção da região e fornecer elementos para uma reflexão sobre o futuro dos sistemas existentes;

- estabelecer, através do esquema de funcionamento, um diálogo com os agricultores sobre os problemas que enfrentam em seus sistemas de produção; 
- contribuir para a avaliação da sustentabilidade econômica, social e ecológica dos sistemas de produção existentes em uma região;

-- auxiliar na formação de engenheiros agrônomos generalistas, pois estimula o desenvolvimento da capacidade de estruturar as bases de várias disciplinas técnicas e a capacidade de formular juízos globais que permitem situar as proposições técnicas no contexto em que ocorrem;

- facilitar a aproximação pluridisciplinar dos engenheiros agrônomos com outros profissionais que tem por objeto de estudo o desenvolvimento agrícola;

As concepções que fundamentam a metodologia proposta coloca limitações. Assim para o estudo de uma agricultura local ou regional é necessário associála a outras abordagens do meio sócio-econômico englobante, em particular de outros agentes e das relações entre estes agentes e os agricultores.

Os tipos de funcionamento construídos a partir das escolhas estratégicas são insuficientes para compreender determinadas escolhas táticas e operacionais. A variabilidade de práticas ao nível do itinerário técnico no interior dos tipos permanece, o que exige um diagnóstico e acompanhamento mais detalhado. 


\section{REFERÊNCIAS BIBLIOGRÁFICAS}

ATtONAy, J. M. Qu'est-ce qu'un système fourrager. Perspective Agricoles, Paris, :20-7, 1980 .

AUBRY, C. Curso de Agronomia. Managua-Nicaragua. Direção General de Tecnologia Agropecuaria - Ministerio de Desarrolo Agropecuario y Reforma Agraria, Abril de 1990. 102p.

BENOIT, M.; BROSSIER, J.; CHIA, E.; MARSHALL, E.; ROUX, M.; MORLON, P.; CHARDIN, B. T. de. Diagnostic global d'exploitaition agricole - une proposition methodologique. Versailles, U.R SAD, 1988. 47 p.

BERTALANFFY, L. von. Teoria geral dos sistema. 2.ed. Petrópolis, Vozes, 1975. $351 \mathrm{p}$

BILLAZ, R. \& DUFUMIER, M. Recherche et Developpement en agriculture. Paris, Presses Universitaires de France, 1980. 190 p.

BONNEMAIRE, J. Diversité et fonctionnement des exploitations. In: JOLIVET, M., ed. Pour une agriculture deiversifié. Paris, Editions L'Harmattan, 1988. p. 92-103.

BONNEVAL, L. de. Vocabulaire français- anglais des systèmes agraires et systèmes de production. Paris, INRA, 1993. $285 \mathrm{p}$. 
BONNEVIALE, J. R., JUSSIAU, R.; MARSHALL, E. Approche globale de l'exploitation agricole; compreendre le fonctionnement de l'exploitation agricole: une méthode pour la formation et le developpement. Dijon, INRAP, 1989. $350 \mathrm{p}$.

BOURGEOIS, A. Une crise des méthodes. Agriscope, Angers, 1 (1): 10-4, 1983 a.

BOURGEOIS, A. Une appication de la notion de systeme : l'exploitatior agricole. Agriscope, Angers, 1(1): 15-31, 1983b.

BOURGEOIS, A. Notions d'agronomie. Angers, ESA, 1985. $401 \mathrm{p}$.

BROSSIER, J. Un essai de liasion entre la recherche, la formation et l'action a partir de l'analyse des décisions économiques des agriculturs. Annales d'Economie et de Sociologie Rurales, Paris, 2(2):111-3, 1973.

BROSSIER, J.; CHIA, E.; MARSHALL, E.; PETIT, M. Recherches en gestion : vers une theorie de la gestion de l'exploitation agricole. In: BROSSIER, J.; VISSAC, B.; LE MOIGNE, J-L., ed. Modelisation systemique et systems agraires - decision et organization. Paris, INRA, 1990. p.65-92.

CAPILLON, A.; SEBILlOTTE, M.; THIERRY, J. Evolution des exploitations d'une petit région : elaboration d'une méthode d'étude. Paris, INA-PG/Roneo Chaire d'Agronomie, 1975. 42p.

CAPILLON, A. \& MANICHON, H. Une typologie des trajectoires d'evolution des exploitation agricoles. Principes et application au développement agricole régional. Compte Rendu de l'Academie d'Agriculture de France, 65(13): 1168-78, 1979. 
CAPILLON, A. Conntaitre la diversité des exploitations: Un préalable a la recherche de références techniques régionales. Agriscope, Angers, 6: 31-9, 1985.

CAPILLON, A. Jugement des pratiques et fonctionnement des exploitations. In: JOLIVET, M., ed. Pour une agriculture diversifié. Paris, Editions L'Harmattan, 1988. p. 124-33

CAPILLON, A. \& MANICHON, H. Guide d'étude de l'exploitation agricole a l'usage des agronomes. Paris, INA-PG/APCA, 1991. 65p.

CAPILLON, A. \& SEBILLOTTE, M. Étude des systémes de production des exploitations agricoles. Une typologie. In: CARIBBEAN SEMINAR ON FARMING SYSTEMS RESEARCH METHODOLOGY. Pointe a Pitre, 1980. Servant, J. ; Pichinat, A. ed. , Pointe a Pitre, IICA-INRA, 1980. p.85-111

CRISTOFINI, B. La région vue à travers de ses exploitations, une outil pou l'amenagement et le developpement rural. Paris, INRA, 1985. 43p.

DAMAIS, G. Algunas consideraciones teoricas sobre el concepto de sistema de production. Heredia/Nicaragua, 1987. 17p. (apontamentos de aula).

DARRÉ, J. P. Production de diversité et production de connaissance. In: JOLIVET, M. ed. Pour une agriculture deiversifié. Paris, Editions L'Harmattan, 1988. . p.141-7.

DEFFONTAINES, J. P. Systèmes agricoles et paysages. In : JOLIVET, M., ed. Pour une agriculture diversifié. Paris, Editions L'Harmattan, 1988. p. 225-32.

DEFFONTAINES, J. P. \& PETIT, M. Comment etudier les exploitations agricoles d'une région? - presentation d'un ensemble methodologique. Versailles, INRA/SAD, 1988. $46 \mathrm{p}$. 
DUFUMIER, M. Systèmes de production et developpement agricole dans le tiersmonde. Les Cachiers de la Rechereche-Développement, Paris, 6:31-8. 1985.

DUMAZERT, P. \& LEVARD, L. Los sistemas de production racionalidades economicas. Managua, Instituto Superior de Ciências Agropecuárias, 1987. 45p. (Projecto elaboration de material didáctico en agronomia)

DURU, M.; GIBON, A.; OSTY, P. L. Pour une approche renouvelée du système fourrager. In : JOLLIVET, M., ed. Pour une agriculture diversifié. Paris, Editions l'Harmettan, 1988. p. 124-33

FAO Desarollo agropecuário : de la dependência al protagonismo del agricultor.. Santiago do Chile, Oficina Regional de la FAO, 1991. 83p. (FAO, Desarollo Rural, 9)

FRESCO, L. O. The study of Farming Systems - a perspective on agricultural technology development. In: . Cassava in shifting cultivation; a systems approache to agricultural technology development in Afrika. Amsterdan, Royal Tropical Institute, 1986. cap. 2, p. 27-39.

GENTIL, D. Faut-il raisonner en terme de vulgarisation ou en terme d'innovation? Paris, IRAM, 1984. $10 \mathrm{p}$.

GRAS, R.; BENOIT, M.; DEFFONTAINES, J.P.; DURU, M.; LAFARGE, M.; LANGLET, A.; OSTY, P.L. Le fait technique en agronomie. Paris, INRA \& L'Harmmatan, 1989. 184p.

HART, R. D. Agroecossistemas - conceptos basicos. Turrialba, Centro Agronomico Tropical de Investigación y Enseñanza, 1979. 211 p. 
HECHT, S. B. A evolução do pensamento agroecológico. In: ALTIERI, M. A. Agroecologia; as bases científicas da agricultura alternativa. Rio de Janeiro, PTA/FASE, 1984.

INRA/SAD Bilan du Département - Rapport géneral - 1979-85. Paris, INRA, 1985. v. $1,111 \mathrm{p}$.

JOLIVET, M. La recherche face à la diversité et a la diversification de l'agriculture. In , ed. Pour une agriculture deiversifié. Paris, Editions L'Harmattan, 1988. p. 301-13.

JOUVE, P. Le diagnostic du milieu rural: de la region a la parcelle. In: MERCOIRET, coor. L'appui aux producteurs; démarches, outils, domaines d'interventions. Paris, Ministére de la Cooperation et du Développement, 1982. 39 p.

JOUVE, Ph. Le diagnostic agronomique: preable aux operation de RechercheDeveloppement. Les Cahiers de la Recherche-Développement, Montpellier, 3-4: $67-76,1984$.

JOUVE, Ph. Approche systemique et Recherche-Developpement en agriculture, quelques definitions et commentaires. In: SEMINAIRE NATIONAL SUR LA LIAISON RECHERCHE-DEVELOPPEMENT-VULGARIZATION, BamakoMali, 1986. Paris, INRA, 1986. 23 p.

JOUVE, Ph. Quelques principes de construction de typologies d'exploitations agricoles suivant differents situations agraires. Les Cahiers de la RechercheDeveloppement, Montpellier, 11: 18-32, 1986.

KUHN, T. A estrutura das revoluções científicas. São Paulo, Edições Perspectiva, 1987. $257 \mathrm{p}$. 
KROLL, J-C. Contribuition méthodologique a l'étude du developpement agricole en sciences sociales. Rennes, ENITA, 1985.. 54 p. (Série synthesés notes et debats, 2)

LANDAIS, E., LHOSTE, Ph. \& MILLEVILLE, P. Points de vue sur la zootechnie et les systemes d'elevage tropicaux. Cahiers des Sciences Humaines, Paris, ORSTOM, 1987.

LANDAIS, E. \& DEFFONTAINES, J. P. Les pratiques des agriculteurs, point de vue sur un courant nouveau de la recherche agronomique. In: BROSSIER, J., VISSAC, B. \& LE MOIGNE, J-L., ed. Modelisation systemique et aystems agraires - decision et organization. Paris, INRA, 1990.. p31-64.

LANDRIÉRE, J. Systèmes. In: Encyclopaedia Universalis, Paris, 15: 686, 1984.

LEFORT, J. Les Recherche-Developpement integres en milieu rural. In: JOURNÉES RECHERCHE-DEVELOPPEMENT EN MILIEU RURAL, Paris, IFARC/GERDAT, 1982. $17 \mathrm{p}$.

LEFORT, J. \& PASQUIS, R-G. Projet de plateforme sur la RechercheDeveloppement integrée en milieu rural. In: JOURNÉES RECHERCHEDEVELOPPEMENT EN MILIEU RURAL, Paris, IFARC/GERDAT, 1982. 9 p. (mimeo).

LEGAY, J. M. Méthodes et modéles dans l'étude des systémes complexes. In: JOLIVET, M., ed. Pour une agriculture deiversifié. Paris, Editions L'Harmattan, 1988. p.4-24.

LE MOIGNE, J-L. La théorie des système general, théorie de la modelisation. 4 . ed Paris, Press Universitaires de France, 1994. 330 p. 
MAZOYER, M. Rapport de synthèse preliminaire présente au "Comitê Dynamique des systemes agraires". Paris, Ministere de la Cooperation et Ministere de la Recherche et de la Technologie, janvier 1986. 15 p.

MAZOYER, M. Ciência e tecnologia a serviço do desenvolvimento agrícola; impasses e perspectivas. Rio de Janeiro, AS-PTA, 1991. 18 p.

MENJON, P. \& D'ORGEVAL, R. Entre atelier et filiére : le système d'élevage. Agriscope, Angers, 1(1): 42-53, 1983.

MILLEVILLE, P. Actes technique et itineraire technique; une méthode d'enquête a l'echelle du terroirs villageois. Les Cahiers de la Recherche Developpement.Montpellier, 3.4: 77-87, 1984.

MILLEVILLE, P. Rechercher sur les pratiques des agriculteurs. Les Cahiers de la Recherche Développement, Montpellier, 15: 17-30, 1987.

MORIN, E. A organização(do objeto ao sistema . In: —_, . O método. I - A natureza da natureza. 2. ed Mem Martim,. 1987. Cap. II:92-145.

OSTY, P. L. Le fait technique en agronomie, point de vue et questions sur quelque concepts. In: BROSSIER, J.; VISSAC, B. ; LE MOIGNE, J-L. ed. Modelisation systemique et aystems agraires; decision et organization. Paris, INRA, 1990. p.19-27.

OSTY, P. L. L'exploitation agricole vue comme un système. Bulletin Technique d'Information, Paris, 326: 43-9, 1978.

PELLECUER, M.; RUF, T. ; HERVÉ, D. Repères méthodologiques pour la Recherche-Développement en agriculture: application à initiation d'une opération au sud de la Thailande. Les Cahiers de la RechercheDeveloppement, Montpellier, 2: 35-43, 1983. 
PERROT, C. \& LANDAIS, E. Comment modéliser la diversité des exploitation agricoles? Les Cahiers de la Recherche- Developpement, Montpellier, 3: 1440, 1993. 1993.

PIAGET, J. O estruturalismo. São Paulo, Difel, 1979. 154 p.

PILLOT, D. L'analyse du milieu ; diagnostic pour l'action. Paris, GRET, 1986. 17 p.

PILLOT, D. Recherche-développement et farming systems research ; concepts, approaches et méthodes. Paris, GRET, 1987. 40 p.

ROSNAY, J. Le macroscope, vers une vision globale. Paris, Editions de Seuil, 1975. $305 \mathrm{p}$.

SANDS, D. M. Farming systems srResearch: clarification of terms and concepts Farming Systems Séries 2. Experimental Agriculture., Great Britain, 22: 87104, 1986.

SASSON, A. Alimentando o mundo de amanhã. Rio de Janeiro, Imago Editora, 1993. $387 \mathrm{p}$.

SAUTTER, G. ed. Comision d'audit du Département de Rescherche sur les Systèmes Agraires et le Developpement ; Rapport géneral. Paris, INRA, 1986. v.1, 43 p.

SEBILLOTTE, M. Agronomie et Agriculture: essai d'analyse des tâches de l'agronome. Cahiers ORSTOM, serie Biol., Paris, 24: 3-25, 1974.

SEBILLOTTE, M. Itineraire technique et evolution de la pensée agronomique. Compte Rendu de l'Academie de l'Agriculture de la France. Paris, 64: 90614,1978 
SEBILLOTTE, M. Analyse du fonctionnement des exploitations agricoles trajectoire et typologie. Note introductive pour la reunion du SAD. In : INRA-SAD ed. Eléments pour une problematique de recherche sur les systèmes agraires et le développement. Paris, 1979. p.20-30

SEBILLOTTE, M. Les systémes de culture: reflexion sur l'interêt de cet notion à partir de l'experience acquise en région de grande culture. In: SEMINAIRE DU DEPARTEMENT D'AGRONOMIE DE L'INRA, Vichy, mars, 1982. Actes, Paris, INRA, 1982. p.63-80.

SEBILLOTTE, M. Système de culture. In: ENCYCLOPOEDIA UNIVERSALIS, 2ed., Paris, 1984. p. $884-7$.

SEBILLOTTE, M.; SOLER, L. G. Les processus de decision des agricultuteurs. In: BROSSIER, J.; VISSAC, B.; LE MOIGNE, J-L. ed. Modelisation systemique et aystems agraires ; decision et organization. Paris, INRA, 1990. p.93-101

SEBILLOTTE, M. Les processus de decision des agriculteurs, consequences pour les demarches d'aide a la decision. In: BROSSIER, J.; VISSAC, B.; LE MOIGNE, J-L. ed. Modelisation systemique et aystems agraires ; decision et organization. Paris, INRA, 1990. p.103-17.

SEBILLOTTE, M. Système de culture, un concept opératoire pour les agronomes. In : COMBE, L. \& PICCARD, D. coord. Les systèmes de culture. Paris, INRA, 1990. $196 \mathrm{p}$.

SIMMONDS, N. W. A short review of farming systems research in the tropics. Experimental Agriculture., Great Britain, 22: 1-13, 1986. 
TESSIER, H. Relations entre techniques et pratiques, consequences pour la formation et la recherche. Paris, INRAP, 1978. 15p. (Bulletin INRAP, 38)

TREBUIL, G. \& DUFUMIER, M. Repérer méthodologiques pour la RechercheDeveloppement en Agriculture; application à l'initiative d'une operation au Sud Thailande. Les Cahiers de la Recherche -Developpement, Montpelier, 2: 35$43,1983$.

WALLISER, B. Systémes et modéles Introduction critique a l'analyse de systèmes. Paris, Éditions du Seuil, 1977. 253p. 
APÊNDICE 1 : Representação da unidade de produção vista como um sistema de produção (adaptado de SEBILLOTTE, 1980)

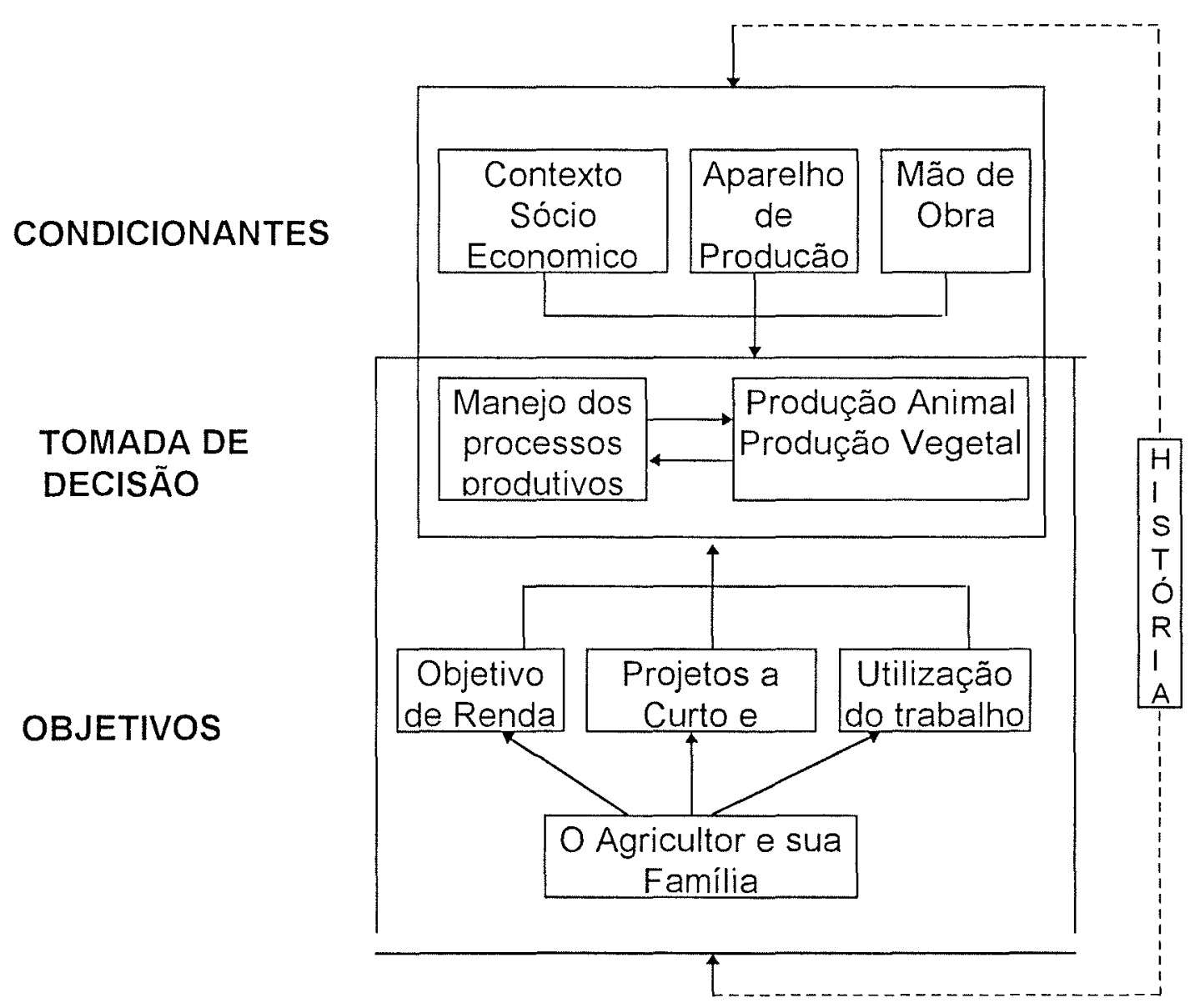


APÊNDICE 2 : Representação do modelo do comportamento adaptativo ( adaptado de BROSSIER et alii, 1990)

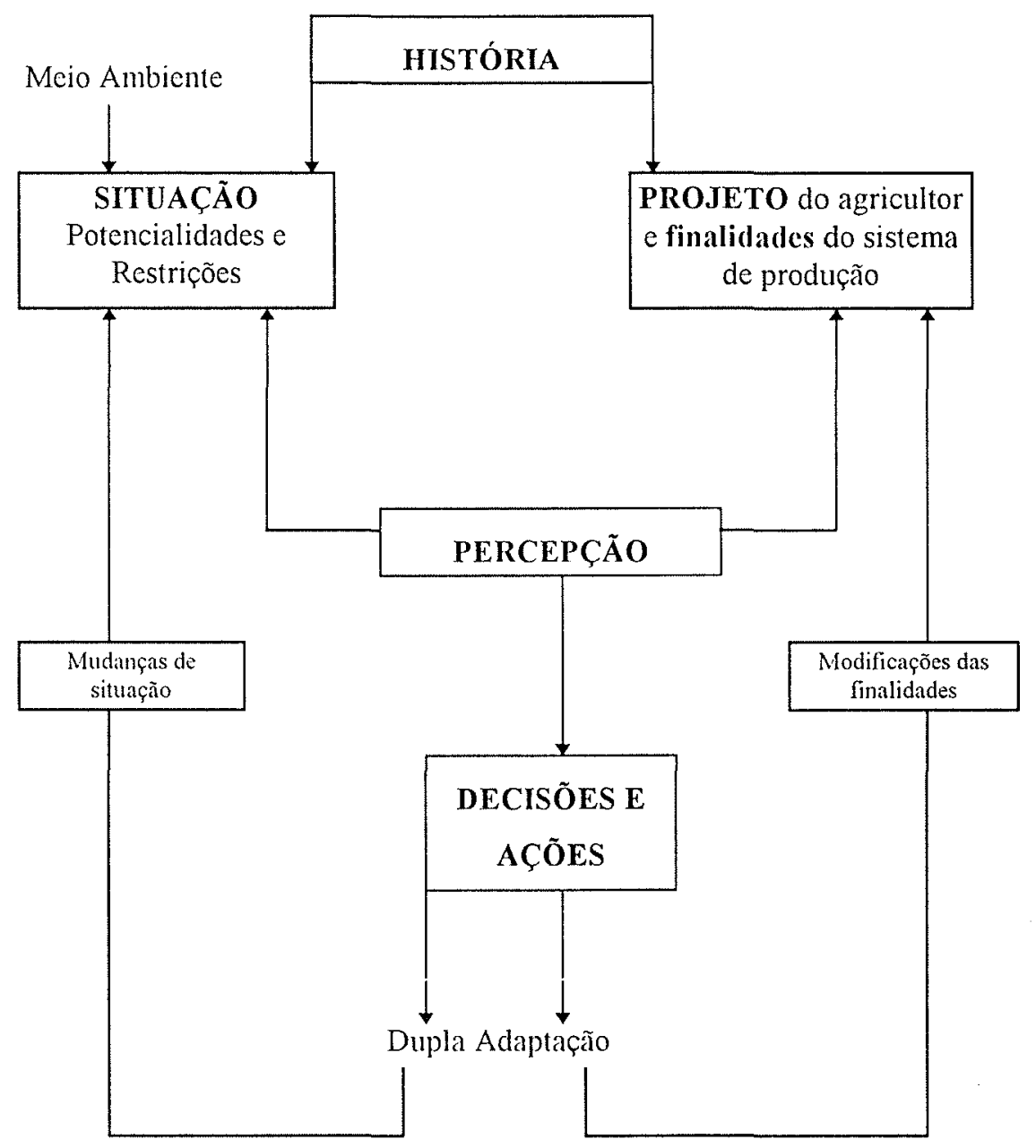


APÊNDICE 3 : Esquema do desenrolar do diagnóstico e tipificação dos sistemas de produção de uma pequena região (adaptado de CAPILLON, 1985)

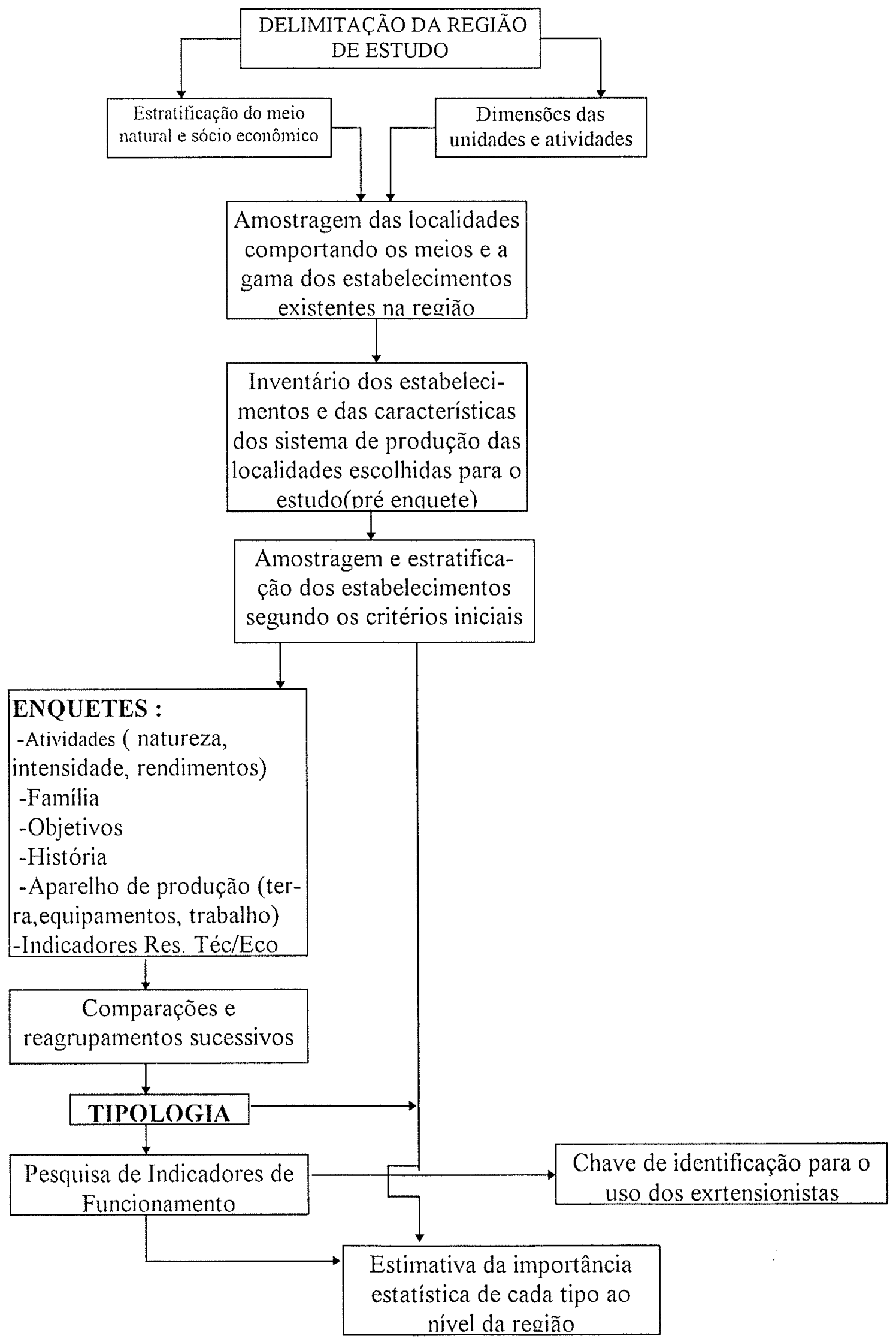

